Reconnaissance geology of the Uqlat As Suqur quadrangle, sheet 25/42A, Kingdom of Saudi Arabia

by

$$
\text { James C. coTe }
$$

Open-File Report 85- 723

\footnotetext{
Report prepared for Ministry of Petroleum and Mineral Resources, Deputy Ministry for Mineral Resources, Saudi Arabia
}

- This report is preliminary and has not been reviewed for conformity with U.S. Geological Survey editorial standards and stratigraphic nomenclature.

I/ U.S. Geological Survey, Denver, Co 


\section{CONTENTS}

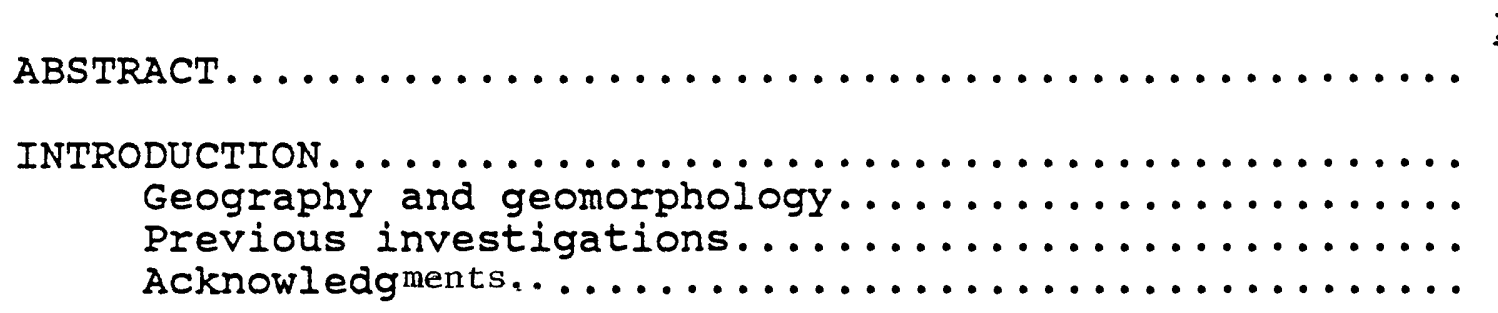

Page

IITHOSTRATIGRAPHIC UNITS AND TERMINOLOGY ............

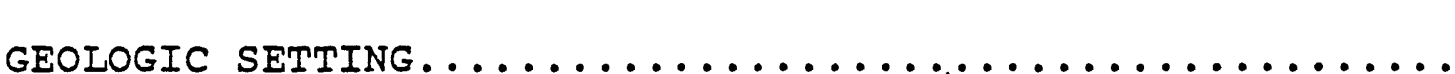

PROTEROZOIC AND PALEOZOIC ILAYERED ROCKS.............. II

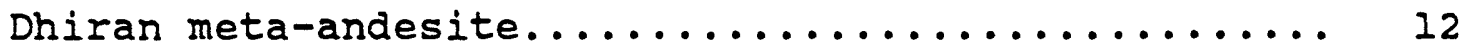

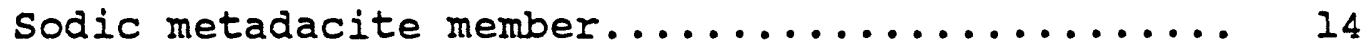

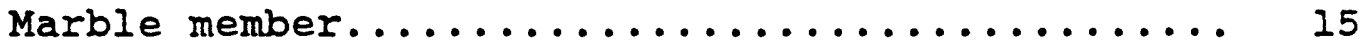

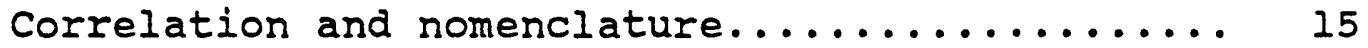

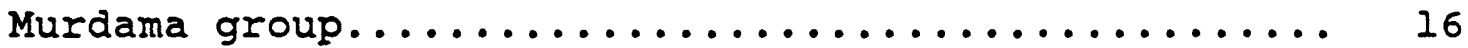

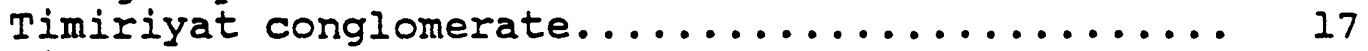

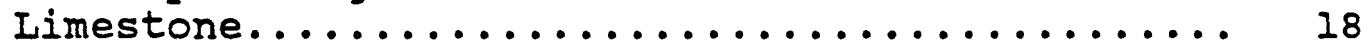

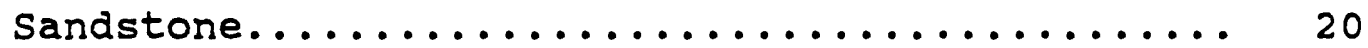

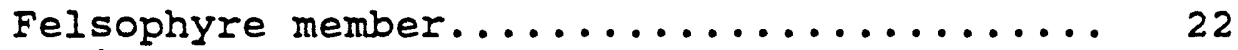

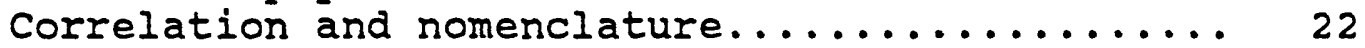

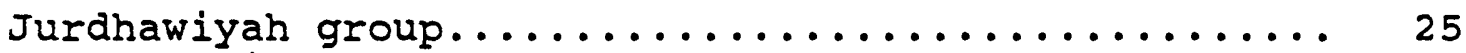

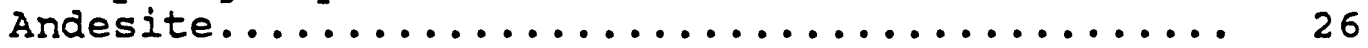

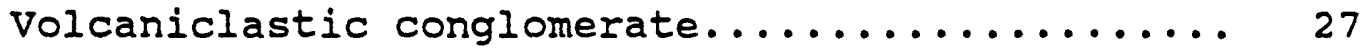

Polymict conglomerate member............. 28

Volcaniclastic sandstone.................. 29

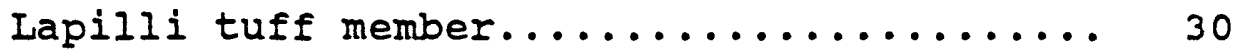

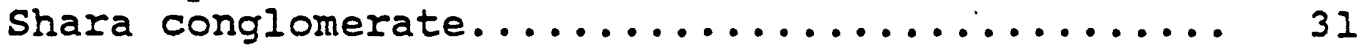

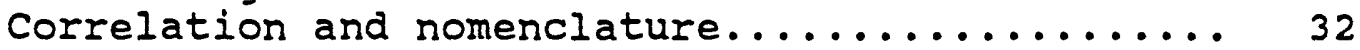

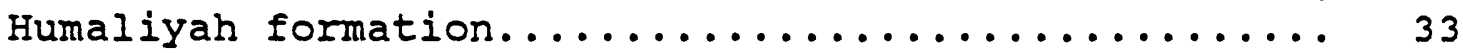

Tuff breccia member.................... 33

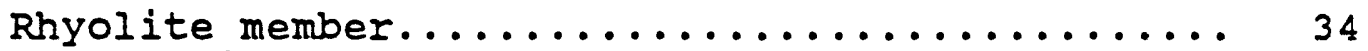

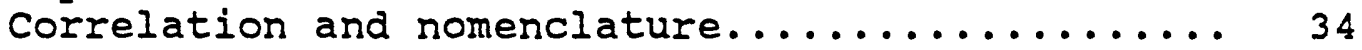

saq sandstone.......................... 35

PROTEROZOIC INTRUSIVE ROCKS...................... 37

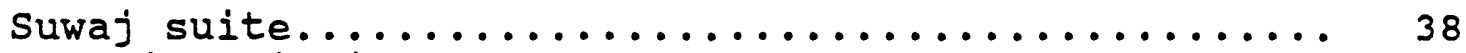

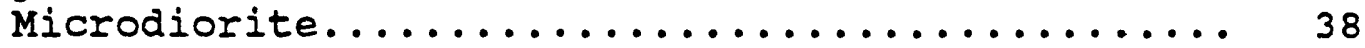

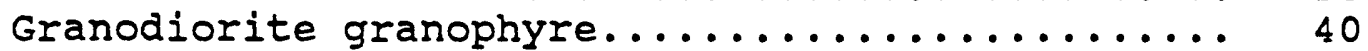

Deformed and altered dike rocks................. 40

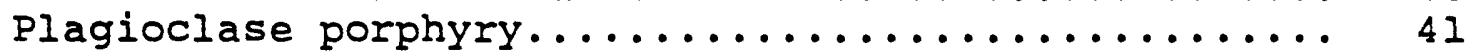

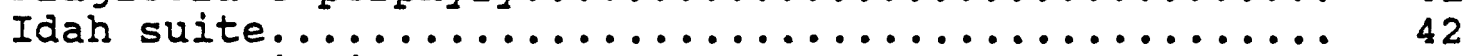

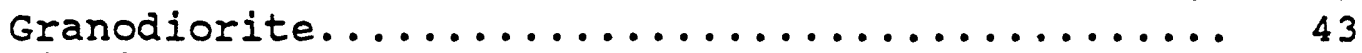

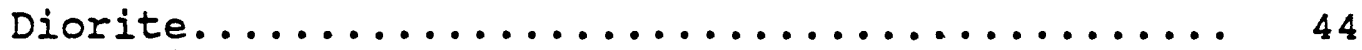

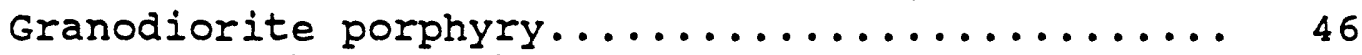

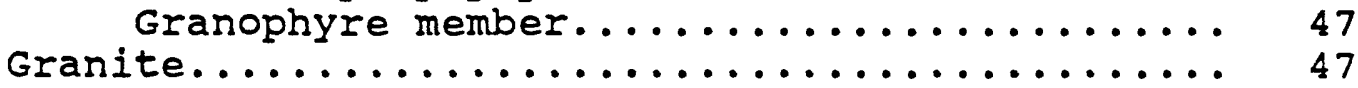

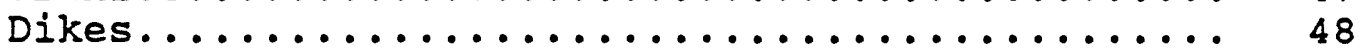

sodic microsyenite......................... 49 
Page

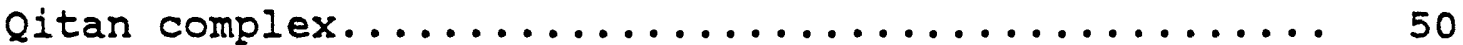

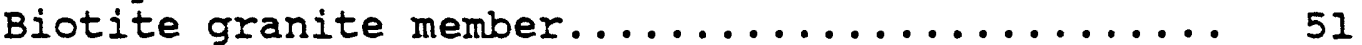

Granite porphyry member................. 52

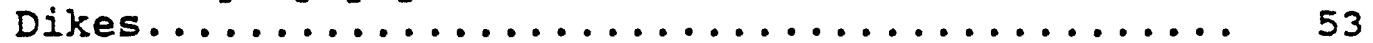

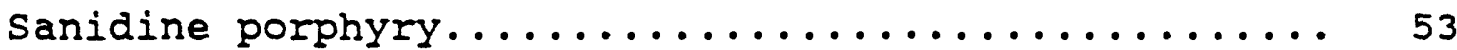

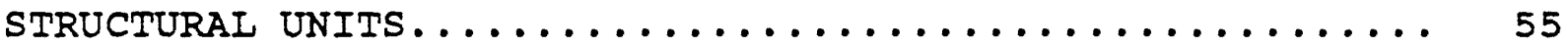

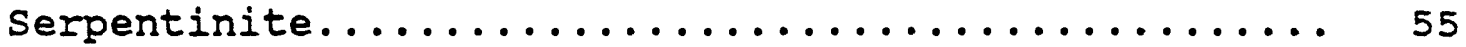

Cataclastic megabreccia.................... 56

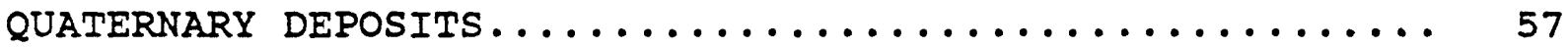

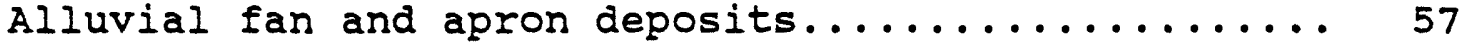

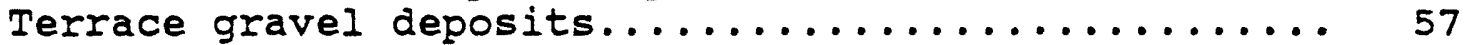

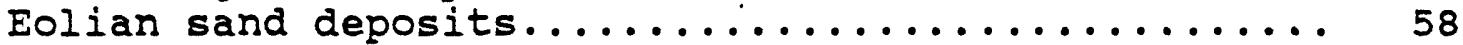

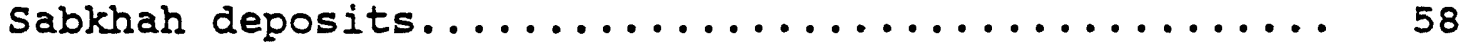

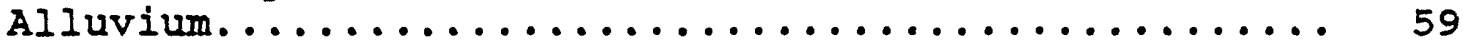

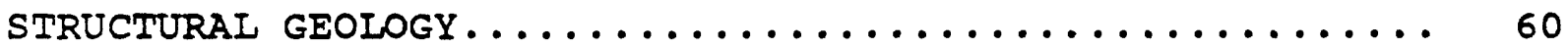

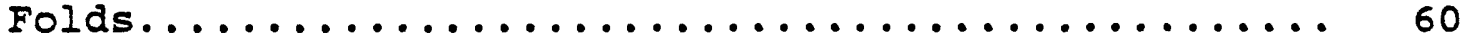

Pervasive schistosity and Iineation.............. 62

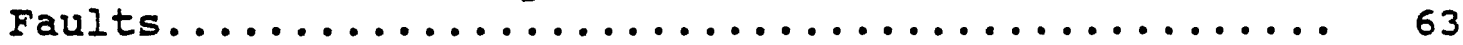

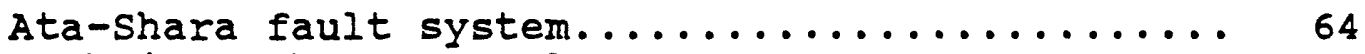

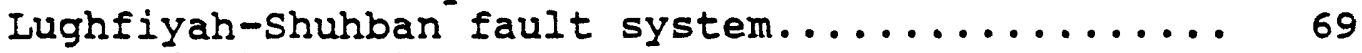

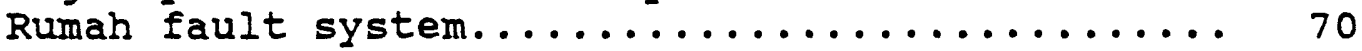

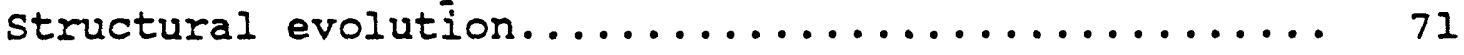

ECONOMIC GEOLOGY............................ 77

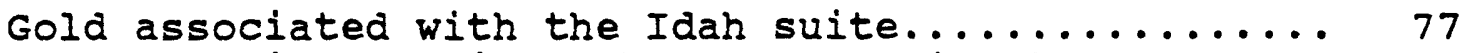

Polymetallic deposits, skarns, and miscellany....... 79

SUMMARY AND REGIONAI IMPLICATIONS................ 81

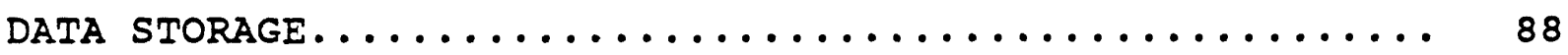

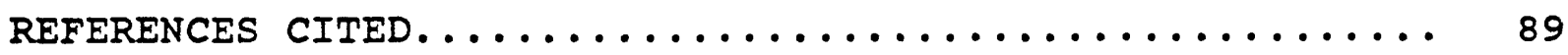

\section{ILLUSTRATIONS}

[Plate is in pocket]

Plate 1. Reconnaissance geologic map of the Uqlat as suqur quadrangle

Figure 1. Location maps for the Uqlat as suqur

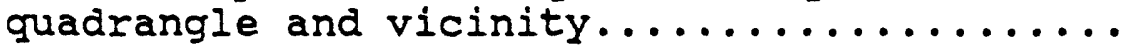

2. Correspondence diagram for lithostratigraphic units defined in the Uqlat as suqur

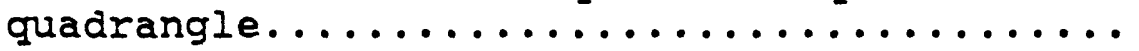

3. Simplified structural sketch map for the Uqlat as suqur quadrangle and surrounding

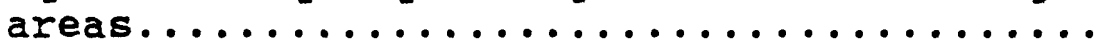


4-6. Modal composition diagrams for rocks of the:

4. Suwaj suite................... 39

5. Idah suite................... 45

6. Qitan complex.................... 52

7. Stereogram of structural data for deformed rocks in the Ata-Shara block...........6 61

8. Faults and fault relationships in the Uqlat as suqur quadrangle.

8 A Map showing faults.................65 $8 \underline{B}-8 \underline{E}$ Cross-sections $B-B^{\prime}$ through $F-F^{\prime} \ldots \ldots 66$ $8 \underline{G}-8 \underline{I}$ Cross-sections $G-G$ ' through $I-I ' \ldots \ldots 67$

9. Interpreted geologic evolution of rock units and structural events for the Uqlat as suqur quadrangle and vicinity... 


\title{
RECONNAISSANCE GEOLOGY OF THE UQLAT AS SUQUR QUADRANGLE, SHEET 25/42 A, KINGDOM OF SAUDI ARABIA
}

\author{
By \\ James C. Cole
}

\begin{abstract}
The geology of the Uqlat as Suqur quadrangle provides a detailed record of the late Proterozoic layered and intrusive rock units, their interrelationships, and the structural evolution of a large portion of the northeastern Shield of Saudi Arabia. Four major unconformities and three well-defined intrusive episodes identified in the quadrangle provide a rational basis for describing and defining lithostratigraphic units, and for interpreting the deformational history within the region.
\end{abstract}

The oldest rocks consist chiefly of low-potassium mafic and felsic metavolcanic rocks (Dhiran meta-andesite) that were intruded $690 \mathrm{Ma}$ to at least $680 \mathrm{Ma}$ ago by the (possibly cogenetic) Suwaj suite, represented in this quadrangle by low-potassium microdiorite and granodiorite granophyre. The Dhiran-Suwaj terrane was deformed and metamorphosed during a regional orogenic event and became the principal source of clastic material for the Murdama group, which was deposited in subsiding marine basins marginal to emergent highlands. Coarse conglomerate and shallow-water limestone were characteristically deposited near these margins, whereas thick, monotonous sandstone accumulated in the deep-water basin centers. The unlithified Murdama deposits were gently deformed but regionally folded along north-south trends between rigid blocks of the Dhiran-Suwaj terrane after about $650 \mathrm{Ma}$.

Regional extension and volcanic activity began at about $640 \mathrm{Ma}$ and produced voluminous calc-alkaline andesite, volcaniclastic sandstone, and volcaniclastic conglomerate of the Jurdhawiyah group. Primary volcanic materials and their rapidly eroded detritus were deposited in linear (probably fault-bounded) basins that were partly shallow-water marine and partly terrestrial. The largest Jurdhawiyah basin began to warp and close during the waning stages of volcanic activity in response to northward-directed compression. High-angle reverse faults displaced the southern basin margin, and a fault-bounded structural arch rose along the northern margin and shed coarse debris into the basin. This intense deformation was closely followed by intrusion of voluminous calc-alkaline granodiorite, diorite, and granite (Idah suite), $620 \mathrm{Ma}$ to $615 \mathrm{Ma}$ ago, that may have been cogenetic with the Jurdhawiyah volcanic rocks. Mineralization is widely associated with this intrusive episode, in the form of gold-bearing quartz veins within and marginal to these plutons.

Uplift, erosion, and probable planation characterized the subsequent interval of about $30 \mathrm{Ma}$, during which no rocks are known to have formed. Beginning at about 585 Ma during a period of regional cratonic extension, high-silica peraluminous granite magma was emplaced in the Qitan complex, and peralkaline magmas were intruded as dikes and extruded as rhyolite and tuff (Humaliyah formation). The Qitan complex and its environs may have potential for tin, tungsten, and(or) base metals.

I/ U.S. Geological Survey, Denver, CO 


\section{INTRODUCTION}

Reconnaissance geologic mapping of the Uqlat as Suqur quadrangle, sheet $25 / 42 \mathrm{~A}$, was conducted as part of a regional program to study the fundamental lithologic, stratigraphic, and structural features of the Arabian Shield to provide a rational basis for mineral exploration activities. The area of investigation is a 30 -minute square of latitude and longitude, approximately $50 \mathrm{~km}$ by $55 \mathrm{~km}$, whose northwestern corner is the intersection of lat $26^{\circ} 00^{\prime} 00^{\prime \prime} \mathrm{N}$. and long $42^{\circ} 00^{\prime} 00^{\prime \prime} \mathrm{E}$. Fig. 1 shows the location of the Uqlat as Suqur quadrangle, surrounding quadrangles, and regional geographic and geologic features mentioned in this report.

Fieldwork was initiated in December, 1980, following interpretation of aerial photographs, Landsat imagery, aeromagnetic and aero-radiometric maps, and existing reports and Mineral Occurrence Documentation System (MODS) files. Mapping of the Uqlat as Suqur quadrangle was done concurrent with fieldwork for the adjoining Al Abanat quadrangle to the east (sheet $25 / 42 \mathrm{~B}$ ). The majority of this work was performed by helicopter, although ground traverses were added in areas that warranted additional detail. Nineteen days of fieldwork were completed in the Uqlat as Suqur quadrangle by the end of April, 1981, but further work was suspended during administrative assignment. Fieldwork was resumed in November, 1983, and completed in December of that year following 10 additional days of helicopter-supported work. In all, 29 days were spent on field investigations, and approximately 440 sites were described and sampled.

Total-count radioactivity was determined for representative outcrops at most all landing sites in 1980-1981. These data proved useful in the initial stages of investigation for characterizing and differentiating rock units, but were not collected during 1983 mapping because, after laboratory examination of 1980-1981 samples, more reliable hand-specimen characteristics had been established.

Cultural and geographic data and barometric altitudes were determined during fieldwork but were superceded during the writing of this report by information released from the Aerial Survey Department, Saudi Arabian Ministry of Petroleum and Mineral Resources (MPMR). Geographic names used in this report are based in this information and conform to the of ficial transliteration (less diacritical marks) for the Kingdom of Saudi Arabia. Mineral locality occurrence names, however, are not necessarily official because they are spelled as they are listed in the MODS data base.

Representative samples of igneous-rock units were analyzed in Jiddah for majorand trace-elements, and various groups of trace-elements were determined for representative samples of layered-rock units and samples collected at known or suspected sites of mineralization. Conclusions arising from study of these results are incorporated in this report, but the raw data are tabulated separately in the project Data File (Cole, 1984b). These analyses and sample locations are also stored in the Rock Analysis Storage System (RASS) computerized data base of the United States Geological Survey (USGS) in Jiddah.

Lithologic descriptions and interpretations of sedimentology, igneous crystallization history, and structural/metamorphic history are based on hand-specimen descriptions, microscopic studies of approximately 400 thin sections, and analysis of rock slabs stained for potassium feldspar. Modal mineral content for holocrystalline igneous rocks was determined on these stained slabs by standard point-count methods. 


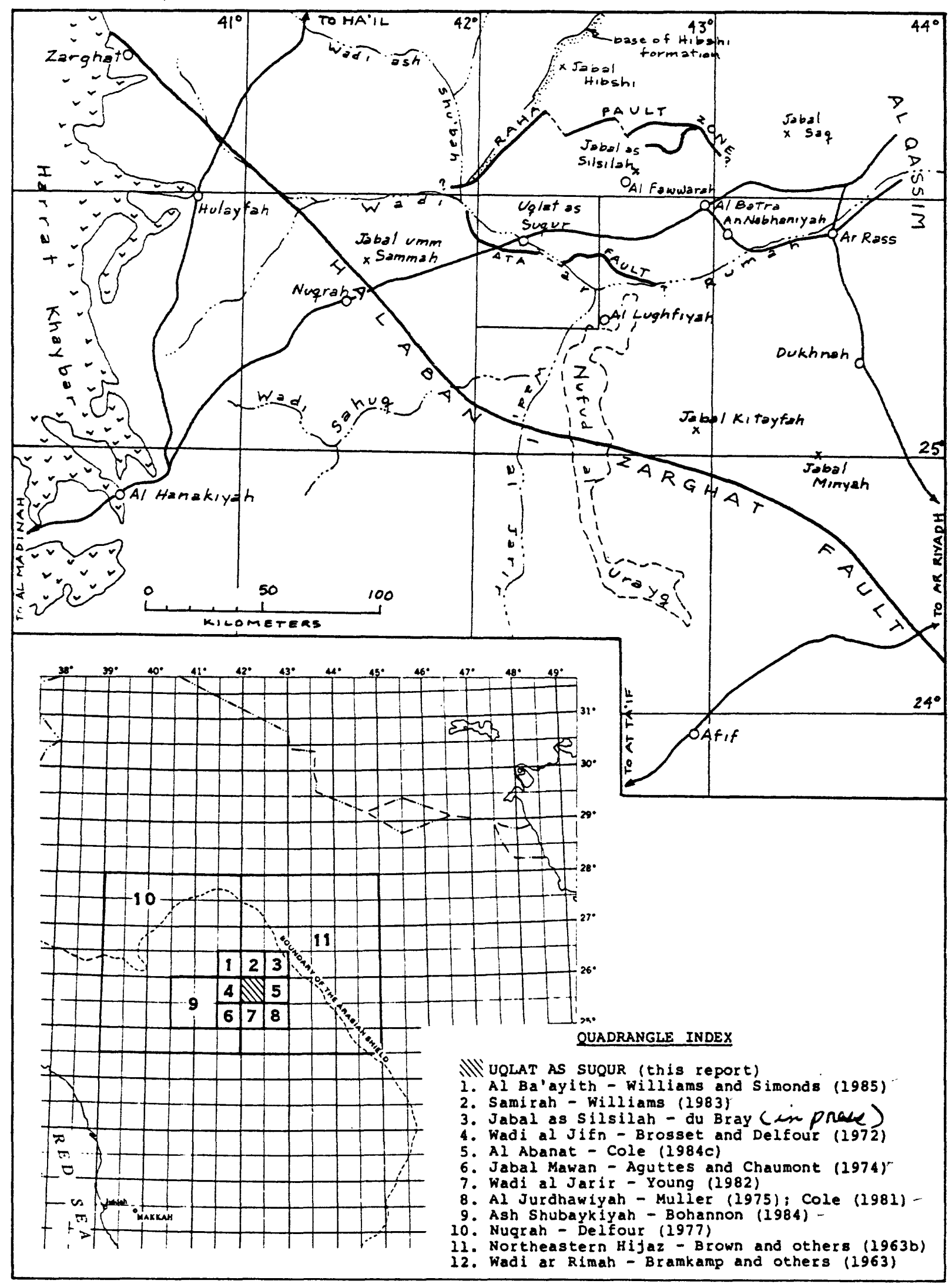

Figure 1.--Location maps for the Uqlat as Suqur quadrangle and vicinity. Geographic and geologic features mentioned in text are illustrated in upper diagram; surrounding quadrangles and references are shown in the lower diagram. 
Mapping and interpretation of structural features of the quadrangle, particularly faults and major lithologic boundaries, were guided and enhanced to a significant degree by analysis of aeromagnetic data obtained by aerial surveys during 1966 and 1967 (ARGAS, 1967). Contoured total-magnetic-field maps at 1:100,000-scale were particularly useful for locating and verifying high-angle fault contacts, whereas upward-continued and rotated-to-pole maps at 1:250,000-scale (Bureau de Recherches Geologiques et Minieres, Saudi Arabian Mission, unpublished data, 1982) proved more useful in defining the edges of major magnetic-rock units (Kleinkopf and Cole, 1982).

\section{GEOGRAPHY AND GEOMORPHOLOGY}

The town of Uqlat as Suqur is the principal established settlement within the quadrangle and, with approximately 2500 inhabitants, is the major governmental and commerciai center for the region east of Nuqrah, south of Al Fawwarah, and west of Al Batra and An Nabhaniyah (fig. 1). Uqlat as Suqur is located on the main paved highway that links Al Madinah in the west with Buraydah and the agricultural centers to the east on the Phanerozoic sedimentary rocks in the Al Qassim province. Easy ground access throughout the quadrangle is available via a network of established, ungraded desert tracks; only the major drainage channels and eolian dune fields restrict travel.

In early 1984, electrification projects were well underway toward providing power to all of the established settlements within the quadrangle, and a high-voltage power line extended as far west as the sub-station at Uqlat as Suqur from the generating facilities in Al Qassim; standard-voltage lines were being constructed to serve the more distant villages. Uqlat as Suqur also contained the only known telecommunications and first aid facilities within the area of the quadrangle.

Topography is typical of the Najd geomorphic province that is characterized by broad, flat tracts of land with little organized drainage, and by local hills, ranges, and inselberg clusters with trellis, dendritic, or radial drainage. The style of drainage is primarily a function of lithology and of regional slope to base level. Radial drainage is typical of structurally homogeneous rocks (for example, granite at Jibal Qitan, weakly bedded conglomerate at Jabal al Idayri, and contact-metamorphosed rocks at Jabal Akkash and Jabal Idah), and around Jabal Timiyah, which is capped by resistant Saq Sandstone. Trellis drainage typifies areas underlain by well bedded rocks that dip more than about $45^{\circ}$, and areas of sub-parallel faults; this drainage pattern is most notable in the southeastern portion of the quadrangle. Dendritic and internal drainage patterns are typical of the remaining areas of the quadrangle.

The maximum altitude in the Uqlat as Suqur quadrangle is $1309 \mathrm{~m}$ on top of the Saq Sandstone cap at Jabal Timiyah. The subhorizontal erosion surface beneath the sandstone and on top of the Proterozoic rocks is at $1190 \mathrm{~m}$. Summit altitudes on the other prominent mountains are $1172 \mathrm{~m}$ at Jibal Qitan $(2 \mathrm{~km}$ north of the quadrangle boundary), $1028 \mathrm{~m}$ at Jabal Idah, and about $1030 \mathrm{~m}$ at Jabal Akkash. Most of the remainder of the quadrangle surface has little relief, and typical altitudes are within the range 840 to $770 \mathrm{~m}$.

The most prominent regional geomorphic feature is Wadi ar Rumah, whose drainage basin includes most of the northeastern Shield as far west as Harrat Khaybar and as far south as Afif (fig. 1). Its principal northern tributary, Wadi ash Shubah, joins Wadi ar Rumah just west of the quadrangle border, and its principal southern tributary, Wadi al Jarir, joins at the eastern quadrangle border. Altitude of the Wadi ar Rumah bed ranges systematically from about $810 \mathrm{~m}$ (west) to $735 \mathrm{~m}$ (east) within the Uqlat as Suqur quadrangle. The width of the channel is typically about one to two 
kilometers; where it is narrower, it is generally bordered by alluvial terrace deposits that record the prior course of the drainage. Wadi ar Rumah is distinctly underfit, and the sparse modern flow is confined to a few braided channels that are no more than $100 \mathrm{~m}$ wide.

Eolian sand only forms thick deposits in the southeastern quadrangle corner near Jabal Idah. This dune field is part of the much more extensive Nufud al Urayq that covers large portions of the adjoining quadrangles to the east and south. Although the eolian deposits are locally as thick as $100 \mathrm{~m}$, rock is generally exposed in the interdune areas.

\section{PREVIOUS INVESTIGATIONS}

Systematic reconnaissance geologic mapping of the Uqlat as Suqur area was first conducted under the USGS program to produce 1:500,000-scale geologic maps of the Shield in the late 1950's and early 1960's. Bramkamp and others (1963) mapped the Wadi ar Rimah quadrangle east of long $42^{\circ} \mathrm{N}$, and Brown and others (1963b) mapped the Northeastern Hijaz quadrangle to the west (fig. 1). Reconnaissance mapping at 1:100,000-scale was conducted in the late 1960's and early 1970's in the areas to the west (Brosset and Delfour, 1972; Aguttes and Chaumont, 1974) and southeast (Muller, 1975) of the Uqlat as Suqur quadrangle. Geologic mapping at this scale was begun in 1979 by the USGS for the Arabian Shield north of lat $25^{\circ} \mathrm{N}$., and Cole (1981), Young (1982), and Williams (1983) mapped the adjoining quadrangles on the southeast, south, and north, respectively. The Nuqrah 1:250,000-scale quadrangle that bounds Uqlat as Suqur on the west was compiled by Delfour (1977) from prior mapping at larger scale.

Aeromagnetic and aero-radiometric data were acquired for the Uqlat as Suqur quadrangle during surveys of the northern Shield (ARGAS, 1967; Andreasen and Petty, 1974). One of the main traverse lines for the Saudi Arabian Kingdom Gravity Net followed the path of the old road from Nuqrah east to Al Qassim, and gravity measurements were made in the vicinity of the Uqlat as Suqur quadrangle (Flanigan and Akhras, 972 end 6 ; Kleinkopf and Cole (1982) interpreted aeromagnetic data for the region immediately south of the quadrangle, and similar techniques were used in this study.

Mineral resource investigations in the quadrangle prior to 1981 chiefly involved examinations of ancient workings, and the extensive excavations at An Najadi (MODS 1272) and Al Habla (MODS 1286) have encouraged repeated study. Following the early reports by Fakhry (1941), Dirom (1946), and Schaffner (1955a, b, 1956), Mytton (1970) summarized the findings as part of a mineral assessment of the Wadi ar Rimah 1:500,000-scale quadrangle. Brief visits to Al Habla are reported by Begg (1980) and by Colliver and Woolett (1981). A refined understanding of the geologic setting of these deposits by the author, and new discoveries by USGS prospectors, led to systematic sampling and re-evaluation at Al Habla (Smith and others, 1984a) and at An Najadi (Smith and others, 1984b).

Geochemical reconnaissance in this quadrangle using drainage-sediment samples was interpreted in 1983, but defined no new (unknown) targets (W. Miller and $R$. Samater, written commun., in praf. The granite at Jibal Qitan was included in a regional assessment of the radio-element potential of the youngest granitic rocks (Stuckless and others, 1982a, b). 
Regional isotopic-age relations have been established by uranium-lead analysis of zircons (J. Cole and C. Hedge, 1984, unpub. data), and the age of the granite at Jibal Qitan was determined by rubidium-strontium whole-rock isochron, and by potassiumargon determinations for biotite and muscovite separates (Stuckless and others, 1984).

Studies of Quaternary geology include investigation of the Wadi ar Rumah drainage (Hotzl and others, 1978) and regional stratigraphy and age-dating (Whitney, 1983). The Riofinex Geological Mission made reconnaissance assessments of the potential for placer deposits (Macdonald, 1982; Boyle and Atkinson, 1982).

As part of a general study of the lithology and stratigraphy of the Murdama group in the eastern Shield, Greene (1984) made observations and measured sections of layered rock in the southern part of the Uqlat as Suqur quadrangle, in the vicinity of Jabal Akkash.

\section{ACKNOWLEDGMENTS}

Reconnaissance geologic mapping of the Uqlat as Suqur was performed by the author as part of a work agreement between the USGS and the Saudi Arabian MPMR. This report completes the specific activities of subproject 2.01.18 of the annual work program for the Saudi Arabian Deputy Ministry for Mineral Resources (DMMR).

Chemical analyses were obtained from the DMMR-USGS Chemical Laboratory under the supervision of K. J. Curry. Ahmed Hamdan al Bathli and Mohamed Ali Jabarti (USGS) determined modal mineral content of the intrusive rocks. Excellent logistic support was provided during the course of this study and for that, I am indebted to $P$. Togans, USGS Field Services Officer and his staff, and to the personnel of the DMMR Special Flight Service.

C. $R$. Thornber (USGS) kindly and thoughtfully reviewed the lengthy original draft and provided many beneficial comments and suggestions. 


\section{LITHOSTRATIGRAPHIC UNITS AND TERMINOLOGY}

Prior interpretations of the geology of the Uqlat as Suqur area and surrounding regions conflict with each other and with the interpretation of this report, to varying degrees. Considerable confusion has arisen as the result of inadequately defined map units and the haphazard use and application of informal stratigraphic nomenclature, particularly for layered units. Since about 1972, almost all of the previously named formation-rank units have been extended and correlated beyond their principal areas of outcrop, and the names no longer denote specific rock assemblages in defined stratigraphic contexts. Similarly, named units of group rank have taken on uncertain connotations because of mistaken assignment of formation-rank units to the group in different parts of the northeastern Shield.

Figure 2 illustrates the layered-and intrusive-rock-unit terminology that has been used in the past, and shows that, even in relation to widely recognized regional unconformities, real disparities exist in the meaning of unit-names. The pictorial bars illustrate (with reference to the units defined in this report) this a uthor's interpretation that, for example, the areas mapped as "Murdama Group" by Delfour (1977) include rocks corresponding to the Timiriyat conglomerate ("Hibshi Formation" of Delfour; 1977), the Limestone and Sandstone units of the Murdama group, and some rocks that correspond to the Jurdhawiyah group (all classified with the "Hadiyah Formation" by Delfour; 1977). Evidence for correlation between units defined in this report and units defined in adjacent quadrangles is contained in the descriptive sections that follow.

All units portrayed on the geologic map ( $p / .2$ described in this report are lithostratigraphic units as defined by the Saudi Arabian Code of Lithostratigraphic Classification and Nomenclature (DMMR, 1984). Layered-rock units are distinguishable first on their relation to regional unconformities, and are classified as formation- or member-rank units based on lithologic and stratigraphic characteristics. Intrusive-rock units are similarly classified and have been aggregated into suites on the basis of shared traits and regional geochronologic studies. All units are described as they are exposed in the Uqlat as Suqur quadrangle, but the definitions are based on structural and stratigraphic relations best exposed, in some cases, in adjoining quadrangles.

Most of the formation- and member-rank units are named according to their dominant lithology and are not prefixed by a geographic locality term. Time was not available to adequately describe and designate type areas, but this report contains as much information as possible regarding the characteristics and bounding surfaces of the units, and the locations of typical and critical outcrops.

Two units portrayed on the map are described under the separate heading of Structural Units. Although they form mappable entities with unifying characteristics, they are neither layered nor intrusive rocks, and they have no stratigraphic context. Their special features are the result of structural dislocation, and they crop out only in the vicinity of fault zones. 


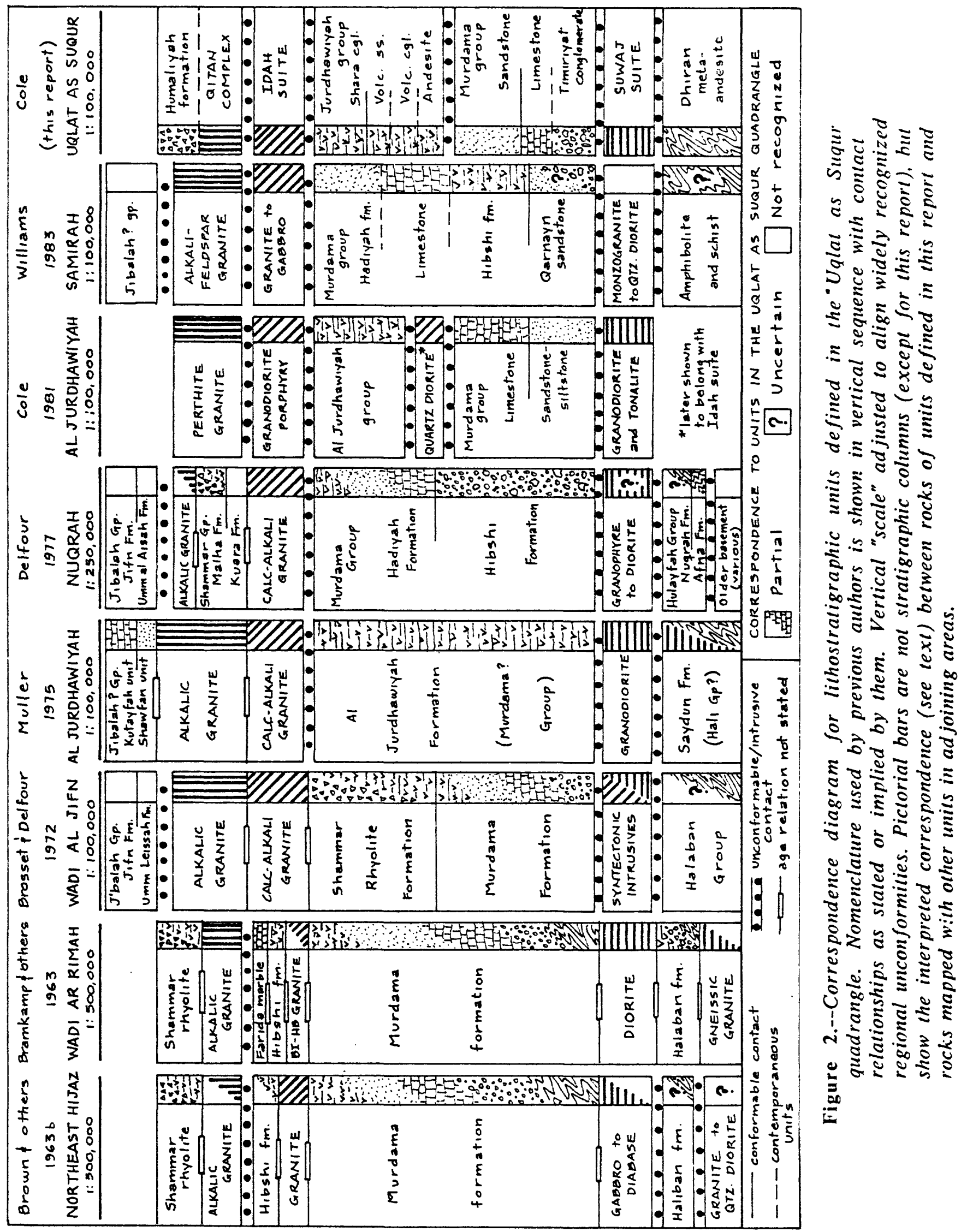




\section{GEOLOGIC SETTING}

With the exception of Quaternary deposits and the singular outcrop of Cambrian and Ordovician Saq Sandstone on the summit of Jabal Timiyah, all rocks of the Uqlat as Suqur quadrangle are upper Proterozoic and formed during the interval between about $700 \mathrm{Ma}$ and $570 \mathrm{Ma}$ ago (Stuckless and others, 1984; Cole and Hedge, 1984, unpub. data). These rocks appear to record the evolution of a part of the Arabian Shield from immature (or nonexistent) continental crust to mature, stable craton in this very short span of time.

Most other parts of the Arabian Shield, particularly south of the Halaban-Zarghat fault (fig. 1), contain appreciable rock that is older than $700 \mathrm{Ma}$ (Baubron and others, 1976; Calvez and Kemp, 1982; Fleck and Hadley, 1982; Calvez and others, 1983; Darbyshire and others, 1983). North of the Halaban-Zarghat fault, the only indications of older rock come from scattered localities. where samples are enriched in radiogenic lead (Stacey and others, 1980) and from reconnaissance age dating north of the base of the Hibshi formation (fig. 1) where metabasalt is intruded by granodiorite, approximately $740 \mathrm{Ma}$ old (C. E. Hedge, written commun., 1983). The geology of this area south of the base of the Hibshi formation and north of the Halaban-Zarghat fault is distinctly younger than other parts of the Shield, and the rocks of the Uqlat as Suqur quadrangle provide a particularly detailed record of the geologic evolution of this area between about $670 \mathrm{Ma}$ and $615 \mathrm{Ma}$ ago.

Four major assemblages are recognized in this region that document the formation of primitive continental crust, its erosion and recycling following orogenesis, widespread calc-alkaline volcanic and intrusive activity, and a late phase of localized partial melting of the matured craton represented by high-silica granite and rhyolite.

The oldest rocks consist chiefly of metamorphosed intermediate and felsic volcanic rocks described as the Dhiran meta-andesite, and were intruded by the Suwaj suite of mafic and intermediate plutonic rocks between 690 and about $680 \mathrm{Ma}$ ago. Rocks of both the Dhiran meta-andesite and the Suwaj suite contain little potassium at all levels of silica content (Cole, 1982, 1984b), and are interpreted to have formed together in an ensimatic setting (or one in which the pre-existing crust was primitive). These rocks are collectively referred to as the Dhiran-Suwaj terrane.

The Murdama group consists dominantly of fine-grained clastic rocks deposited in several north-trending marine basins defined by fault-bounded blocks of older units. The Murdama appears to represent debris shed from orogenic uplift(s) that were active during the deformation and metamorphism of the Dhiran-Suwaj terrane. The period of Murdama sedimentation is not directly known, but it was terminated by gentle regional folding, probably during the interval $655 \mathrm{Ma}$ to $640 \mathrm{Ma}$ ago (Cole and Hedge, 1984, unpub. data).

Deposition of volcanic and volcaniclastic rocks of the Jurdhawiyah group, beginning about $640 \mathrm{Ma}$ ago, and the slightly younger intrusive rocks of the Idah suite record the third major phase of evolution of the northeastern Shield. The Jurdhawiyah group is dominated by volcanic rocks of andesitic composition that form a calk-alkaline evolutionary series with minor dacite and rhyodacite. These volcanic products and their rapidly eroded detritus were deposited in spatially restricted, structurally active, epicontinental basins. Structural and stratigraphic relations, particularly well exposed in the Uqlat as Suqur quadrangle, indicate that the principal Jurdhawiyah depositional basin there was deformed during deposition, and that sedimentation ceased as a result of northward-directed compression. Intrusion of calc-alkaline magmas of the Idah suite 
in circular and elliptical plutons marks the end of this magmatic and deformational cycle at about $620 \mathrm{Ma}$ to $615 \mathrm{Ma}$ (Cole and Hedge, 1984, unpub. data).

Following emplacement of the Idah suite, the succeeding $30 \mathrm{Ma}$ interval was probably characterized by uplift, erosion, and planation, because no rock units or structures are known to have formed. Between about $585 \mathrm{Ma}$ and $570 \mathrm{Ma}$, leucocratic granitic magmas intruded the matured crust of the northeastern Shield (Stuckless and others, 1984) and granite of the Qitan complex and rhyolite and ignimbrite of the Humaliyah formation were formed at this time.

Continued erosion and planation appear to have overlapped the emplacement of the latest granites and their volcanic counterparts. Beginning in early Cambrian time, Saq Sandstone was deposited above a largely planar unconformity surface, but the youngest Proterozoic granites were topographically prominent during initial deposition.

Events that transpired during the remainder of Phanerozoic time are not recorded in the Uqlat as Suqur quadrangle, nor on the Shield in general. The morphology of the landscape and the deposition of Quaternary detritus are believed to be the result of regional uplift of the craton during its separation from the Nubian Shield along the Red Sea axis, beginning perhaps as early as middle Miocene time (Schmidt and others, 1982). Climatic evolution over the last few million years toward generally arid conditions has reduced the rate of landform change (Whitney, 1983), and has led to the accumulation of eolian sand, chiefly during the last few hundred thousand years. 


\section{PROTEROZOIC AND PALEOZOIC LAYERED ROCKS}

The layered rocks of the Uqlat as Suqur quadrangle consist chiefly of sedimentary and volcanic rocks. Clear unconformity relationships have been mapped between most of the units, and structural features further serve to define five layered assemblages. From oldest to youngest, these assemblages are the Dhiran meta-andesite (including metadacite and minor marble), the Murdama group (polymict conglomerate, limestone, sandstone, and felsophyre), the Jurdhawiyah group (andesite, volcaniclastic conglomerate and sandstone, lapilli tuff, and polymict conglomerate), the Humaliyah formation (tuff breccia and rhyolite), and Saq Sandstone.

The Dhiran meta-andesite crops out only in the east-central part of the quadrangle in a structurally elevated block. The Murdama group is the most widespread layered unit and was deposited in three discrete basins. The Jurdhawiyah group crops out chiefly in the southern portion of the quadrangle in an east-west basin that is superimposed on the Murdama basin geometry. The Jurdhawiyah also defines the relic of a smaller basin in the northwestern corner of the quadrangle. A small fault-bounded block along the western border of the quadrangle preserves the only remnants of the Humaliyah formation. The Cambrian and Ordovician Saq Sandstone forms a sub-horizontal cap on the summit of Jabal Timiyah, and is described and discussed with the Proterozoic layered rocks because its genesis is more allied to these older units than with the other Phanerozoic units (Quaternary deposits).

Descriptive terminology for clastic and chemical sedimentary rocks is based on the classification scheme of Folk (1968). Volcanic rocks are described on the basis of phenocryst content according to the classification recommended by the International Union of Geological Sciences (Streckeisen, 1978) or, with a vailable chemical data (Cole, $1982,1984 \mathrm{~b}$ ), according to the normative classification scheme of Irvine and Baragar (1971). Terminology for pyroclastic rocks is based on Fisher $(1961,1966)$.

The Dhiran is variably schistose and regionally metamorphosed to greenschistfacies assemblages, but most younger layered rocks of the quadrangle are only slightly modified by post-depositional alteration and recrystallization. The textures and mineral assemblages are consistent with diagenetic alteration (Schiffman and others, 1984), and metamorphic-rock terms are not used for the Murdama and Jurdhawiyah groups because they would be misleading. Mineral schistosity is locally present in the Murdama, but only as a result of later, intense deformation. Thermal metamorphism in the contact zones of some intrusions is spatially restricted and produces distinctive textures and mineral assemblages, described in the following sections.

Epidote-group minerals and carbonate minerals are widespread, both as detrital grains and as part of alteration assemblages. Quite commonly, more than one of the minerals epidote, zoisite, and clinozoisite are present, but without discernable textural or age distinction; all are referred to collectively as "epidote". Similarly, all carbonate minerals are referred to collectively as "calcite", except where evidence warrants specific mineral names (for example, dolomite or sideritic carbonate). 
Rocks of the Dhiran meta-andesite comprise the oldest layered units of the quadrangle, and consist chiefly of altered and locally schistose andesitic and (sodic) dacitic metavolcanic rocks. The Dhiran is exposed chiefly in the east-central part of the quadrangle in the Ata-Shara block (fig. 3), and is defined in this report and named for Shaib adh Dhiran. In the southeastern corner of the quadrangle between Wadi al Jarir and Nufud al Urayq, altered and recrystallized metavolcanic rocks crop out structurally below (overturned) limestone of the Murdama group, and these rocks are correlated with the Dhiran. In the adjoining Al Abanat quadrangle to the west (Cole, 1984c), similar rocks crop out south of Wadi ar Rumah (fig. 1) where they are widely intruded by foliated quartz diorite of the Suwaj suite.

The Dhiran poses problems for lithostratigraphic classification because it has no recognized base, its internal stratigraphy is nebulous, its structural history appears to have been complex, and it is regionally exposed in discontinuous areas. It is described as a formation-rank unit because it consists dominantly of mafic metavolcanic rocks in this and the adjoining Al Abanat quadrangle. Distinctive sodic metadacite and marble are described as members of the Dhiran because they are mappable entities, but the internal organization of the unit is unclear because of widespread deformation within the Ata-Shara block. The subdivisions of the Dhiran are described below in order of decreasing abundance. Relative ages are not implied by the order of presentation in the report nor in the description of units on the geologic map.

The stratigraphic position of the Dhiran is established by two relationships exposed in the Uqlat as Suqur quadrangle. Southeast of Jibal al Khusayyayn, the Dhiran meta-andesite is intruded by microdiorite and granodiorite granophyre correlated with the Suwaj suite, and the age of the Suwaj requires that the Dhiran is older than 690 Ma (Cole and Hedge, 1984, unpub. data). Secondly, abundant clasts of both the Dhiran and Suwaj units are contained in the Timiriyat conglomerate at the base of the Murdama group. North of the confluence of Wadi ar Rumah and Wadi al Jarir at the eastern border of the quadrangle, the Dhiran is unconformably overlain by andesite and sandstone of the Jurdhawiyah group, and polymict conglomerate beds in the Jurdhawiyah also contain clasts of Dhiran and Suwaj.

More than 90 percent of the Dhiran consists of black to dark-green, fractured, locally schistose metavolcanic rocks (da) that approximate andesite in bulk composition. Their origin as volcanic deposits is confirmed by relict phenocrysts of plagioclase and pyroxene/amphibole(?), by common amygdules and planar zones of amygdaloidal rock, and by breccia textures defined by irregular and angular clasts of meta-andesite in a meta-andesite matrix. Primary structures at outcrop scale are generally absent, and the orientation of original layering could not be established. The most characteristic outcrop-scale structure is irregular, nonoriented, anastomosing seams of altered and granulated rock rich in epidote, chlorite, and quartz. These seams, the lack of $\mathrm{fresh}$ pyroxene or hornblende, and the pervasive epidote-green color on un weathered surfaces distinguish Dhiran meta-andesite from Jurdhawiyah andesite.

Primary igneous textures are preserved, but most of the original minerals are converted to assemblages of coarse and granular epidote, chlorite, actinolite-tremolite, calcite, sphene, and quartz. Plagioclase is marginally replaced by calcite and epidote, and the fact that most feldspar is oligoclase suggests calcium was lost during recrystallization. Hornblende is absent, but its original presence is indicated by chlorite relics with granular sphene and leucoxene along amphibole cleavage planes. Trace amounts of pale augitic pyroxene are locally present, although it has largely been replaced by chlorite and actinolite. 

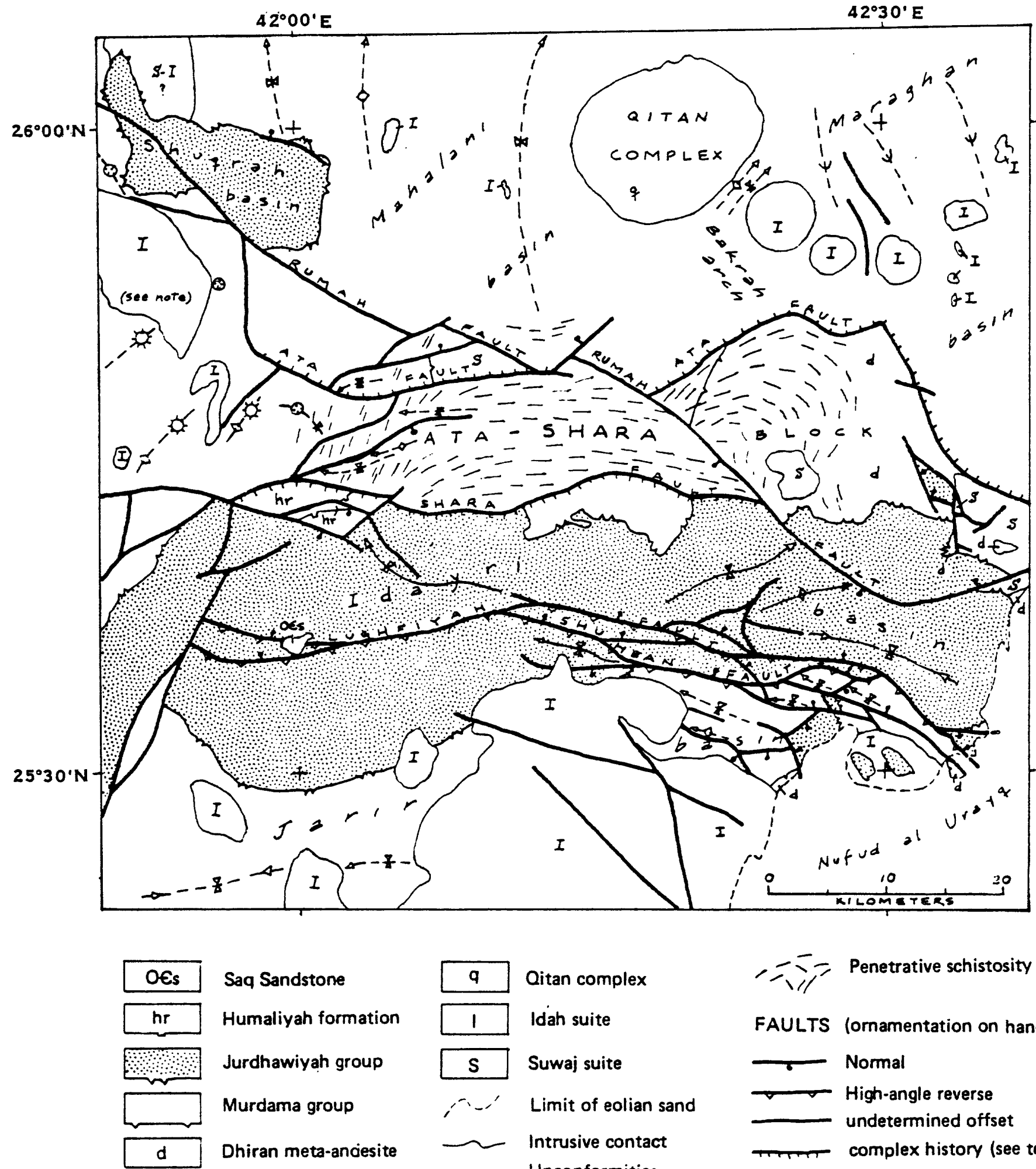

Saq Sandstone

Humaliyah formation

Jurdhawiyah group

Murdama group

Dhiran meta-anciesite

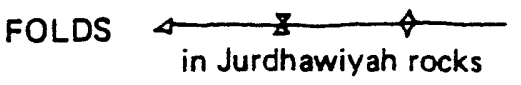

ハテデ Penetrative schistosity

FAULTS fornamentation on hanging wall side

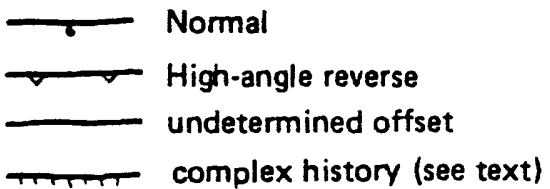

$\triangleleft-8-\diamond-\leftarrow--$

in Murdama rocks

dome basin

Figure 3.--Simplified structural sketch map for the Uqlat as Suqur quadrangle and surrounding areas. Idah-suite pluton south of Shuqrah basin is part of the "Ar Rahadah batholith" of Delfour (1977). 
Relict amygdules, filled with mosaic quartz and patchy calcite, are generally deformed and all of the quartz is strongly undulatory. Meta-andesite contains abundant veins of quartz, calcite, and epidote that are also typically deformed and irregular. Much of the original matrix material is replaced by spongy calcite porphyroblasts, and by very fine grained epidote, actinolite, quartz, and oligoclase. Opaque minerals are marginally or totally replaced by sphene and leucoxene.

The Dhiran meta-andesite is uniform in outcrop aspect and petrography throughout the quadrangle, with the local exception of primary textural variations (structureless, fragmental, and amygdaloidal). In the vicinity of lat $25^{\circ} 42^{\prime} \mathrm{N}$., long $42^{\circ} 27^{\prime} \mathrm{E}$. and lat $25^{\circ} 43^{\prime} \mathrm{N}$., long $42^{\circ} 28^{\prime} \mathrm{E}$., however, minor amounts of thinly bedded biotite-hornblende schist, biotite-chlorite schist, and rare marble (not shown on map) appear to be interlayered with meta-andesite. Some coarser-grained rocks within the Dhiran consist of plagioclase phenocrysts surrounded by granophyric mantles that merge with the groundmass, and these rocks are texturally and mineralogically gradational with microdiorite of the Suwaj suite.

\section{Sodic metadacite member}

Areas within the Dhiran indicated by a caret pattern (pl. 1) correspond to outcrops of the sodic metadacite member (dq). Because of pervasive deformation and the lack of internal stratigraphy in the Dhiran, it was not possible to map distinct contacts around the metadacite at 1:100,000-scale. The caret pattern reflects the general distribution of this lithology and the pattern bands are parallel to local contacts between meta-dacite and meta-andesite. The significance of the apparent distribution of metadacite is uncertain on the basis of present evidence; bedding, folded bedding, structurally dismembered contacts, or a combination of factors may have produced this distribution.

Pervasive chlorite-muscovite schistosity, relict quartz and plagioclase phenocrysts, and a distinctive brown-gray color on weathered surfaces mark the appearance of metadacite in outcrop. The local colluvium has a similar color that contrasts with green-hued colluvium derived from meta-andesite, and this contrast is a useful mapping tool. The most characteristic and abundant outcrops of the metadacite unit are located east of Shaib al Khusayyayn.

The unit is named sodic metadacite (in contrast to meta-dacite) to emphasize the unique mineralogy and apparent chemical composition. It contains phenocrysts of sodic plagioclase and quartz only, relict mafic minerals are very rare, and all samples reacted negatively to the potassium-sensitive staining procedure. Thus, the rock is a dacite on the basis of phenocryst content, but is quite different from calc-alkaline dacite that is typical, for example, in the Jurdhawiyah group. The lack of relict mafic phenocrysts suggests these rocks originally crystallized from a sodic magma, although they may have lost additional calcium, potassium, and other elements during submarine or metamorphic alteration.

Typical metadacite contains more than 40 percent relict phenocrysts, and the plagioclase and quartz grains tend to be about 2 to $4 \mathrm{~mm}$ in diameter. The large size and abundance of these grains produce a distinctly nubbly texture on schistosity planes. Subhedral plagioclase phenocrysts or glomerophenocrysts are present in all samples, but the proportion of quartz phenocrysts is more variable and ranges from zero to about 50 percent of the total phenocryst volume. These quartz grains are clearly relict phenocrysts because they retain their original subhedral shape and embayed perimeters. 
The plagioclase phenocrysts are typically unzoned sodic oligoclase, and are partially to completely replaced by epidote, sericite, and calcite. Relict mafic grains are absent, although rare clusters of opaque grains and chlorite were probably derived from amphibole. The matrix consists of granular to slightly elongate quartz, sodic plagioclase, chlorite, sericite, spongy calcite, and granular epidote.

The pervasive schistosity in sodic metadacite is defined by aligned plates and aggregates of muscovite and chlorite, by dimensional alignment of matrix quartz and feldspar, and locally by weak compositional banding. This fabric molds around the relict phenocrysts but does not pass through them. Quartz phenocrysts are strongly elongate parallel to schistosity and have pronounced undulatory, ribbon extinction, whereas plagioclase phenocrysts are rarely fractured or undulose. Post-depositional calcite and epidote are locally twinned and bent. In some samples, thin veins composed chiefly of mosaic quartz define extremely disharmonic, ptygmatic folds whose axial planes are parallel to the mica schistosity.

\section{Marble member}

Small pods and discontinuous layers of white to brown-gray marble (dm) crop out within the Dhiran, but only the body near lat $25^{\circ} 50^{\prime} \mathrm{N}$., long $42^{\circ} 30^{\prime} \mathrm{E}$. is large enough to show at the scale of the map. Marble crops out within meta-andesite and in association with rare (metasedimentary?) biotite schist, but for the same reasons noted for the sodic metadacite member, the stratigraphic position of this marble is unknown.

The layer shown on the geologic map is about 10 to $20 \mathrm{~m}$ thick, and displays a weak compositional banding subparallel to its length. This banding is locally folded on decimeter scales in a disharmonic style. The marble consists chiefly of fine-grained, micritic, brown calcite that is riddled with sparry calcite veins of diverse orientations. Much of the sparry calcite is twinned, bent, and otherwise strained, which implies deformation post-dates recrystallization of the original limestone.

\section{Correlation and Nomenclature}

The overall composition, structure, and style of the Dhiran meta-andesite distinguishes it from all other layered-rock units in the Uqlat as Suqur quadrangle, and from most other units in the northeastern Shield. The fact that it is unconformably overlain by the Murdama group and intruded by plutonic rocks of the Suwaj suite, two widespread units in this part of the Shield, allows a rational basis for comparison with other layered-rock units in similar stratigraphic position (see fig. 2).

Muller (1975) recognized similar metavolcanic and schistose rocks in the quadrangle to the west that he described, along with altered intrusive rocks, as the Saydun Formation. He also noted that abundant clasts near the base of the Jurdhawiyah group (Al Jurdhawiyah Formation of Muller, 1975) establish the stratigraphic position of these rocks. However, Muller's Saydun Formation was abandoned by the DMMR Stratigraphic Committee in 1984 because it was improperly defined to contain both layered and intrusive rocks. The intrusive rocks are defined in this report as parts of the Suwaj suite.

Bramkamp and others (1963) did not distinguish Dhiran-type rocks from their Murdama formation in this region at 1:500,000-scale, but their reconnaissance was based chiefly on photointerpretation. West of long $42^{\circ} 00^{\prime}$ E., most of the layered rocks northeast of the trace of the Halaban-Zarghat fault (fig. 1) have been correlated with the Murdama Formation (Brosset and Delfour, 1972) or the Murdama Group (Delfour, 1977; Humayliyah synclinorium). Study of the Murdama southwest of the 
Uqlat as Suqur quadrangle defines an unconformable base to that unit above "meta-andesite" (Greene, usy data) that resembles the Dhiran (Arnold, 1984). On the basis of these observations and interpretation of Landsat images and aerial photographs, it is probable that much of the Murdama Group of Delfour (1977), described as "biotite schist" or "injection gneiss and migmatite" between the Ar Rahadah batholith (fig. 3) and approximately long $41^{\circ} 52^{\prime} \mathrm{E}$., may correlate in part with the Dhiran meta-andesite (Cole, this report). For this reason, figure 2 also indicates a partial correspondence of the Murdama formation of Brown and others (1963b) in the Northeastern Hijaz 1:500,000-scale quadrangle with the Dhiran of this report.

Dhiran meta-andesite occupies a similar stratigraphic position (that is, pre-Murdama and coeval with low-potassium intrusive rocks) to that described for the Halaban and(or) Hulayfah groups in the eastern and northern Shield (Delfour, 1977; Hadley and Schmidt, 1979; Schmidt and Brown, in pren). However, lack of outcrop continuity with Halaban/Hulayfah, lack of agreement on the definition and correlation of these groups, and lack of direct age control for the layered rocks argue against any simple correlation of the Dhiran. Although this report proposes that the Dhiran is roughly coeval with the Suwaj suite (about $690 \mathrm{Ma}$ to $680 \mathrm{Ma}$ old) and is thus much younger than traditional age estimates for the Halaban and Hulayfah groups (Fleck and others, 1980; Greenwood and others, 1982; Calvez and others, 1983), figure 2 indicates possible correspondences between the Dhiran and rocks previously mapped with these loosely defined groups. Xenoliths of amphibolite and schist in $650 \mathrm{Ma}$ old quartz diorite north of this quadrangle (Williams, 1983; Cole and Hedge, 1984, unpub. data) may also correspond to the Dhiran (fig. 2).

\section{MURDAMA GROUP}

Rocks of the Murdama group are exposed over about half of the Uqlat as Suqur quadrangle, and are contiguous with extensive outcrop in the adjoining regions, particularly to the west and northeast (Delfour, 1977; Cole, 1981, 1984c; du Bray, inpen; Williams, 1983). The Murdama throughout most of the northeastern Shield consists chiefly of immature, fine-grained, monotonous, thinly bedded sandstone, but discontinuous lenses of limestone and polymict conglomerate are common near the base of the group (Greene, 1983; 1984 deta). The lithologic character and general internal stratigraphy of the Murdama group are similar in the Uqlat as Suqur quadrangle, although the basal conglomerate and limestone units are exceptionally thick in places, and a distinctive felsophyre member is locally interbedded with sandstone and forms a useful marker bed.

The geographic distribution of the basal Timiriyat conglomerate and the basal Limestone unit defines the margins of three discrete depositional basins of the Murdama group (fig. 3). In the northern part of the quadrangle, the Mahalani basin and the Maraghan basin are separated by the Bakrah arch (Cole, this report). This arch is underlain by Dhiran-Suwaj terrane, covered by thin, near-basal Murdama deposits, and is interpreted to have been structurally high during Murdama deposition. South of the Lughfiyah fault, Murdama rocks were deposited in the Jarir basin that appears to extend southward for at least $50 \mathrm{~km}$, and perhaps farther beyond the Halaban-Zarghat fault (fig. 1; Cole, 1981, imprew; Young, 1982; Greene, 1983; Pellaton, 1984b).

The stratigraphic position of the Murdama group is well defined in the Uqlat as Suqur quadrangle. The Timiriyat conglomerate rests unconformably on the Dhiran meta-andesite northwest of Dihlat al Hasat and contains abundant clasts of Dhiran metamorphic rocks and plutonic rocks of the Suwaj suite. Limestone of the Murdama group also rests unconformably on the Dhiran, as exposed on the east side of Wadi al 
Jarir at the southern quadrangle boundary. The Murdama, moderately to intensely folded, is unconformably overlain by rocks of the Jurdhawiyah group at various localities (particularly well displayed in the northwestern and southwestern corners of the quadrangle). The absolute age of the Murdama is constrained between about $680 \mathrm{Ma}$ and $620 \mathrm{Ma}$ because it rests on the Suwaj suite and is intruded by the Idah suite (Cole and Hedge, 1984, unpub. data). However, the absolute time range for Murdama deposition is considerably shorter than this $60 \mathrm{Ma}$ interval because undated felsic members of the Suwaj may be younger than $680 \mathrm{Ma}$ and because the Jurdhawiyah group is also older than $620 \mathrm{Ma}$.

\section{Timiriyat conglomerate}

Very distinctive polymict conglomerate (Mtc) forms the basal unit of the Murdama group in the Uqlat as Suqur quadrangle, and is particularly thick and widely exposed along the southern margin of the Mahalani basin (fig. 3). The base of the unit is not exposed in most localities, because of structural dislocation or cover by younger units, but the Timiriyat rests atop a nearly planar unconformity surface above the Dhiran meta-andesite northwest of Dihlat al Hasat. This site is within the Ata-Shara block, however, and the contact is obscured by penetrative deformation. North of the western extension of the Ata fault (fig. 3) in the Sumar al Hasat hills, this conglomerate is only weakly deformed, but it is separated from pre-Murdama granodiorite granophyre (Suwaj suite) by a few hundred meters of sandstone.

This unit is defined in this report and named for the area of Jibal Timiriyat in the central portion of the fault-bounded Ata-Shara block (fig. 3) where the widest and most characteristic exposures are found. This area is probably undesirable as a type locality, however, because of local post-Murdama deformation and low-grade metamorphism. Absolute thickness of the Timiriyat is unknown and is likely to be highly variable along strike and from place to place, but the unit clearly is conformably interlayered with the Sandstone unit everywhere near its top (toward the west in this quadrangle). This interlayering is gradual and gradational both along strike and across strike, and the contact between Timiriyat and the Sandstone unit was arbitrarily located at the limits of dominantly conglomeratic beds.

One aspect of the relationship of the Timiriyat to the Sandstone unit of the Murdama is displayed at Sumar al Hasat. Conglomerate crops out in an east-west band at a high angle to the general north-south trend of bedding. In detail, conglomerate beds pass north and south along strike into finer grained sediments, without structural dislocation between the units. The same relationship was mapped a short distance to the west (up-section) by Brosset and Delfour (1972) at Jabal abu Isbah, and the conglomerate-sandstone contact there is also a facies change (Cole, this report). The east-west conglomerate band, therefore, represents the axis of a long-lived conglomerate channel during deposition of the Murdama in this area, and points to the fact that the Timiriyat is not a neatly time-bounded unit.

Typical Timiriyat conglomerate consists of abundant subangular to subrounded cobbles and some boulders of diverse lithologic types, although most of them have clear counterparts in the rocks of the Dhiran meta-andesite and the Suwaj suite. Based on observations of undeformed Timiriyat, the conglomerate is very poorly sorted, indistinctly bedded, and contains few primary sedimentary structures. Local cut-and-fill channel structures indicate the consistent westward facing of the unit in the southern part of the Mahalani basin, and bedding is generally defined by variations in clast size, degree of packing, and by local pebbly sandstone beds. 
The dominant clasts consist of Dhiran meta-andesite and medium-grained hornblende diorite and granodiorite granophyre of the Suwaj suite. Distinctive clasts that are generally present but less common include Dhiran metadacite, brown and varicolored marble, hornblende microdiorite, vein quartz, various felsic metavolcanic rocks, phyllite (mica schist), and some sandstone that closely resembles Murdama sandstone. The matrix, which generally makes up less than 15 percent of the rock, consists of progressively finer-grained fragments of the same rocks and of their more resistant constituent minerals (quartz, plagioclase, and some detrital epidote).

In undeformed (nonschistose) Timiriyat, the conglomerate is densely cemented by secondary epidote, quartz, and calcite. Most of the mafic minerals in the clasts are replaced by chlorite, epidote, granular sphene, and oxide minerals and plagioclase is altered to sericite, epidote, and calcite. These mineral assemblages characterize the Dhiran-Suwaj source terrane for the Timiriyat, and because the clast minerals are locally bent and twinned whereas the cement is not, most of this alteration probably happened prior to deposition in the Timiriyat.

Schistose Timiriyat, characteristic of the central part of the Ata-Shara block, is a most remarkable looking rock in outcrop. Clasts are extremely flattened and elongated in the plane of mineral schistosity, and the extent of this deformation correlates with the mechanical competency of the original clast lithology. Plutonic-rock clasts are least deformed and only slightly ellipsoidal, but are closely fractured perpendicular to the elongation axis and the segmented fragments have further rotated toward the plane of schistosity; fractures are filled with veins of undeformed quartz, calcite, and chlorite. Metavolcanic-rock clasts are generally flattened to ellipsoids with the major axis typically 3 to 6 times longer than the minor axis. Incompetent materials, particularly marble, are extremely flattened and extended to rod shapes. The degree of flattening and elongation is variable within the quadrangle, as described below in the section on Structural geology.

Mineral schistosity and penetrative foliation in the Timiriyat conglomerate are genetically related to the deformation of the clasts. In outcrop, these fabrics define curviplanar zones that weave between the clasts and intersect in the direction. of elongation. Where the amount of flattening has been relatively minor, outcrops are dominantly lineated and the schistosity planes appear as two inclined sets. Where flattening and extension are more extreme, outcrops have a more foliated aspect as a result of the convergence of the inclined schistosities, and the lineation produced by the long-axes of clasts is even more pronounced.

Minor outcrops of conglomerate are present beneath limestone and, in places, above Dhiran meta-andesite near the east end of the Lughfiyah fault in the adjoining Al Abanat quadrangle (fig. 3; Cole, 1984c). These conglomerates are correlated with the Timiriyat on the basis of lithology and stratigraphic context, and are believed to mark the northern margin of the Jarir depositional basin of the Murdama group. In general, conglomerate in these localities is finer grained than in the Ata-Shara block, but the clast assemblage, matrix, and texture of the rock are similar.

\section{Limestone}

Locally as much as several hundred meters of shallow-water limestone and impure sandy limestone (Ml) are present at or near the base of the Murdama group, particularly along the northern margin of the Jarir depositional basin (fig. 3). Major outcrops of this unit in the Uqlat as Suqur quadrangle are repeated in a complexly faulted band that extends from the southeastern quadrangle boundary west through Jibal ash Shuhban, and are also exposed at the southeastern margin of Jibal Qitan (across the 
Bakrah arch). The lithologic description that follows applies as well to limestone beds interlayered with the bottom of the Sandstone unit which, where prominent in outcrop, are indicated by a brick pattern on the geologic map.

Limestone rests unconformably on probable Dhiran meta-andesite near the southern border of this quadrangle on the east side of Wadi al Jarir (contact overturned), and conformably on top of thin Timiriyat conglomerate over Dhiran a short distance to the east (Cole, 1984c). The base of the limestone near Jibal Qitan is not exposed. Limestone and impure limestone pass upward in all sections into dominantly clastic sediments of the Sandstone unit by progressive interlayering; contacts between these units were defined at the top of the highest prominent limestone bed.

The Limestone unit of the Murdama is classified as a formation-rank entity, but it is not named for a geographic locality because no adequate section is present in the Uqlat as Suqur or adjoining quadrangles. The thickest section, the best outcrops, and best exposure of the internal arrangement of the Limestone unit are at Jibal ash Shuhban and vicinity, but post-Murdama deformation along high-angle faults has produced a jumble of rotated blocks that reduce this area's utility as a type section.

The Limestone unit has an internal organization that is repeatedly exposed in several of the fault blocks at Jibal ash Shuhban. The lower part typically consists of two massive beds, each about $70 \mathrm{~m}$ thick, separated by 5 to $10 \mathrm{~m}$ of thinly bedded limestone and impure limestone. The massive beds are brown to tan in outcrop, show little evidence of internal primary layering, and are locally crisscrossed by fractures filled with white sparry calcite. Above these two massive beds, limestone and impure limestone alternate in beds ranging from a few centimeters to about a meter thick, and internal laminations are common on a millimeter scale. These well bedded sections tend to crop out with brown, tan, bluish-black, and black colors. The thick limestone southeast of Jibal Qitan appears to have a similar organization consisting of one or more massive beds below laminated rocks, although the base is not exposed. In general, bedding within the limestone is markedly planar and continuous for hundreds of meters along strike.

Fossil stromatolites have only been identified in one locality in the Uqlat as Suqur quadrangle. On the south bank of Shaib al Humaliyah at lat $25^{\circ} 42^{\prime} 27^{\prime \prime} \mathrm{N}$., long $42^{\circ} 03^{\prime} 20^{\prime \prime} \mathrm{E}$. (indicated by symbol on geologic map), several continuous beds contain abundant red-orange, silicified relics of stromatolite heads. The typical cross-sectional diameter of these structures is one to two centimeters, and they are internally laminated in concentric shells approximately 0.2 to $0.5 \mathrm{~mm}$ thick. The shells are defined by changes in the grain size of granular calcite, by silicified layers, and by concentrations of minute plagioclase laths, devitrified shards, and rare detrital grains of monocrystalline quartz and radial chalcedony. Several percent deep purple fluorite fills late fractures and replaces some growth shells; the source of the fluorine is unknown.

Small, lensoid blocks of noncarbonate rock (too small to portray on the geologic map) are contained in the Limestone unit in this quadrangle, and they seem to be regionally associated with Murdama limestone (Cole, 1981, 1984c; Pellaton, 1984a). Fine-grained, structureless to flow-banded, reddish-brown rhyolite(?) blocks near Jabal Idah are contained in limestone that is tightly folded and riddled with sparry calcite veins. Rotated lensoid blocks of well-bedded, calcite-cemented pebble conglomerate are also exposed in contorted limestone; the pebbles consist only of microcrystalline felsic volcanic rock that are extremely well rounded, well sorted, and cemented by coarse, 
sparry calcite. Both the rhyolite and the pebble conglomerate blocks appear to be boudin fragments of competent tabular bodies, and the lithology of both suggests minor silicic volcanic activity during early Murdama sedimentation.

Murdama limestone is characteristically contorted and bedding defines shallow-plunging folds with several hundred meters amplitude and kilometer-scale wavelengths. Disharmonic folds at outcrop scale are locally present on the limbs of larger folds, and are accompanied by tension fractures filled with sparry calcite. Limestone is further deformed and recrystallized near faults to a dense, dark-colored rock that contains abundant white calcite veins.

The bulk of the carbonate is pale-brown, micritic ooze that is locally and irregularly recrystallized to coarse, sparry calcite. Most samples of Murdama limestone contain as much as 10 percent fine-sand grains composed of (in order of decreasing abundance) subhedral sodic plagioclase, rounded felsic volcanic rock fragments, quartz, devitrified shards, and minor Murdama sandstone, sphene, opaque minerals, and some granophyre that resembles the Suwaj granodiorite granophyre. Some medium-sand fragments form the cores of ooliths ( 1 to $3 \mathrm{~mm}$ in diameter) that are concentrated in thin beds.

Murdama limestones are recrystallized to varying degrees in proximity to younger intrusions. North and northwest of Jabal Idah, coarsely crystalline white and blue marble indicate the effects of thermal metamorphism, although the contact with granodiorite porphyry of the Idah suite is everywhere buried by Quaternary deposits. Relict bedding in the limestone outlines the shapes of disharmonic folds of variable orientation, and suggests widespread plastic flow during recrystallization. Calc-silicate minerals were not found near the Idah contact, but are common on the southeast margin of Jibal Qitan, where skarn (several hundred meters thick) contains an assemblage of calcite, relict quartz, porphyroblastic diopside and andesine, and local epidote and garnet.

\section{Sandstone}

More than 60 percent of the Murdama outcrop and perhaps as much as 90 percent of the total volume of Murdama in the Uqlat as Suqur quadrangle consists of fine-grained clastic sediments (Ms) that comprise a formation-rank unit designated Sandstone. The base, marked by gradational contacts with the Limestone unit or Timiriyah conglomerate, is exposed in many localities in the quadrangle, but the top is truncated everywhere by unconformities.

Very similar rocks characterize the bulk of the Murdama group throughout the eastern and northeastern Shield (Johnson, 1983a; Greene, 1983, 1984 undedand various local, informal unit-names have been used (Hadigah formation, Zaydi formation, Maraghan lithic graywacke), although the units have not been sufficiently defined (Delfour, 1977, 1979; du Bray, inpuew). Because the sandstone is well bedded and crops out uniformly over broad regions, estimates of thickness range from about $10 \mathrm{~km}$ (Delfour, 1979) to an unrealistically large figure of $26 \mathrm{~km}$ (Greene, 1983). The internal stratigraphy of the Sandstone unit is poorly known, and more work is required before distribution and thickness can be understood in relation to syndepositional and postdepositional folding and faulting. This report documents several independent depositional basins for the Murdama and, although sandstone in each is similar, the basin structures and evolutionary histories are not sufficiently known to define type localities. Thus, no geographic term is attached to the Sandstone unit. 
Exposure of this unit is typically poor as a result of pervasive and close-spaced fracture cleavage, fine grain size, and thin bedding. The sandstone crops out best in this quadrangle along the Bakrah arch south of Al Khullah and in the Jarir basin east of Al Habla (fig. 3 ; pl. 1). These beds are more resistant because of denser carbonate cement and, perhaps, because of diffuse contact metamorphic effects near Idah-suite plutons.

Murdama sandstone forms low, linear ridges separated by strike valleys. Beds are planar, decimeters to about one meter thick, and continuous for hundreds of meters along strike. Centimeter to millimeter laminations are apparent in some outcrops, but the variation from dominantly medium sand to fine sand and coarse silt is typically subtle. Slightly more resistant beds consist of very coarse sand with rare granules and pebbles. Small-scale primary sedimentary structures (grading, ripple marks, cross-stratification) are rare and difficult to identify because of the poor quality of outcrop.

Sandstone is interbedded with Timiriyat conglomerate and the Limestone unit and interfingers with the tops of these units both along strike and up-section. Sandstone is not in contact with the Dhiran-Suwaj terrane except west of Uqlat as Suqur town at about lat $25^{\circ} 49^{\prime}$ N., long $42^{\circ} 09^{\prime}$ E., where a few hundred meters of sandstone underlie Timiriyat conglomerate and appear to rest on Suwaj-suite granodiorite granophyre. However, the contact is not exposed and may be faulted.

Murdama sandstone is typically green on fresh surfaces, generally contains enough carbonate cement to react to dilute acid, and characteristically contains scattered martite relics of cubic pyrite. Free detrital quartz generally makes up at least 10 percent of the rock and is discernable with a hand lens. Fresh amphibole and pyroxene, either as detrital grains or as phenocrysts in fragments of volcanic rock, are absent.

Clasts in the sandstone are typically green, white, and (rarely) brown or red, and can be identified with four principal source-terrane lithologies. Altered, intermediate volcanic rock fragments are dominant and are characterized by plagioclase microlites (commonly with moderate trachytic alignment), plagioclase phenocrysts, chlorite pseudomorphs of pyribole phenocrysts, and an indistinct matrix of chlorite, granular sphene, epidote, and pale actinolitic amphibole. Felsic volcanic rock fragments (second in abundance and locally dominant) are characterized by relict eutaxitic and spherulitic textures, by a general lack of relict phenocrysts, and by quartz-rich matricies with felted, tabular feldspars, scattered chlorite, epidote, sphene, and rare amphibole. Detrital plagioclase is third in abundance and was probably derived from volcanic phenocrysts and coarse-grained plutonic rocks. The fourth major clast type (zero to 15 percent of the total population) is interpreted to be plutonic rock fragments, and includes monocrystalline quartz grains, phaneritic quartz-feldspar rock fragments (plagioclase, potassium feldspar, or both), and very widespread clasts of distinctive, graphic quartz-potassium feldspar intergrowths.

The composition of most Murdama sandstone is calcitic, siliceous, immature volcanic arenite, but samples with more than 15 percent detrital plagioclase are classified as feldspathic volcanic arenite. Individual grains, regardless of composition, are chiefly angular to subangular, and rough estimates of the clast size-distribution suggest that the overall sorting is poor to moderate. Matrix consists chiefly of very fine grained rock fragments, and fine-grained chlorite, epidote, quartz, and calcite. Carbonate cement is locally abundant and replaces the matrix as coarse, irregular patches of calcite or rhombic dolomite. 
Murdama sandstone is regionally metamorphosed and schistose only within the Ata-Shara block (fig. 3). Chlorite and sericite are common authigenic minerals throughout the Murdama, but are more coarsely crystalline and form a pervasive schistosity within this block. The metamorphic transformation is easily recognized in outcrop by the easy platy parting of the rock and by a weak phyllitic sheen on the parting surfaces. Metamorphic chlorite and sericite exhibit weak crystallographic orientation, but are concentrated along subparallel surfaces that mold around the larger detrital clasts. In schistose sandstone, quartz, epidote, and calcite are more coarsely crystalline than in nonschistose sandstone, and rare porphyroblasts of chlorite and gray-brown to blue-gray tourmaline locally enclose the chlorite-sericite schistosity.

Thermal effects in proximity to younger plutons are more limited in extent and are only distinguishable within a few hundred meters of the intrusive contacts. In contrast to unmetamorphosed sandstone, hornfelses are darker in color, more resistant to erosion, and produce a higher-pitched tone when struck. Quartz is distinctly glassy and clear, the matrix is dark brown (rather than green), and fine sandstone is typically mottled by porphyroblastic minerals. Microscopic evidence of recrystallization is indicated by very fine grained brown biotite flakes, granular magnetite (hornfelsed rock is distinctly more magnetic), and annealed, mosaic quartz. Rare porphyroblasts of cordierite (replaced by pinite; isotropic and weakly birefringent phyllosilicate minerals) and a few grains of staurolite are locally present within a few tens of meters of contacts, and minor fluorite is typical adjacent to granite of the Qitan complex.

Felsoohvre member.--Thin, continuous layers of structureless, sparsely porphyritic siliceous rock are interlayered with the Murdama sandstone in the west-central part of the quadrangle in the vicinity of Al Jimariyah. The structure of the area and the outcrop of the felsophyre member suggest that two distinct layers are present, separated by about $600 \mathrm{~m}$ of sandstone. The more continuous layer is about 10 to $20 \mathrm{~m}$ thick and forms a useful marker bed that outlines kilometer-scale folds. Felsophyre is pale orange to tan in outcrop and on fresh surfaces, and it contrasts markedly with the green ard blue-green colors of the sandstone and the Timiriyat conglomerate.

Felsophyre consists of a fine-grained mosaic of quartz, plagioclase, and potassium feldspar. Relict phenocrysts comprise 5 to 10 percent of the rock, are generally less that $2 \mathrm{~mm}$ in diameter, and are chiefly sodic plagioclase and quartz (potassium feldspar is rare). The uniform composition of the unit, the relict phenocrysts, and its discrete and strike-continuous bedform suggest it originated as volcanic ash. This ash was probably transported prior to burial, however, as indicated by a few percent grains of multidomain quartz that are rounded and clearly detrital.

This unit crops out chiefly in the Ata-Shara block (fig. 3) where the Murdama has been metamorphosed. The felsophyre in this area contains as much as 15 percent metamorphic sericite that forms a weak schistosity parallel to chlorite-muscovite schistosity in the surrounding sandstone. However, the beds have been more competent than sandstone, they are segmented by boudinage, and abundant quartz veins fill tension fractures in the felsophyre.

\section{Correlation and Nomenclature}

The assemblage of basal polymict conglomerate and shallow-water limestone with voluminous immature sandstone has been repeatedly identified as the essential characteristic of the Murdama group in the northeastern Shield (fig. 2). With the exception of the all-encompassing reconnaissance Murdama-unit used in the earliest mapping (Brown and others, 1963b; Bramkamp and others, 1963), the major difference between the Murdama of this report and that of others is the definition and 
stratigraphic position of the basal conglomerate unit. Muller's (1975) mistaken interpretation of the structure at Jabal Kitayfah (fig. 1) led to an erroneous correlation of limestone and sandstone with the Jibalah(?) group, but the interpretation was resolved by later mapping (Cole, 1981) that established the Jabal Kutayfah Formation of Muller (1975) belongs with the Murdama group.

The Timiriyat conglomerate, defined in this report, forms the local base of the Murdama group and is characterized by a clast assemblage derived from the DhiranSuwaj terrane. These source materials were altered and regionally metamorphosed prior to deposition in the Timiriyat and the plutonic-rock clasts, in particular, are distinctive because they consist exclusively of low-potassium diorite, quartz diorite, and granophyric granodiorite. The Timiriyat is superficially similar to conglomerate of the Jurdhawiyah group (chaotic deposition, poor sorting, local presence of plutonic rock fragments, and dominance of clasts of intermediate volcanic rock), but the critical discriminant is that volcanic debris in the Jurdhawiyah is fresh and contains abundant pyroxene and amphibole, whereas pyriboles in clasts deposited in Timiriyat conglomerate are wholly replaced by chlorite and actinolite.

Figure 2 shows that the Hibshi formation (defined by Bramkamp and others, 1963) at Jabal Hibshi (fig. 1) was interpreted as a post-Murdama unit, whereas later mapping of the same rocks by Williams (1983) interpreted the Hibshi formation as a basinmargin facies of the Murdama, separated from sandstone and limestone by a thrust fault. In my opinion, this confusion stems from the erroneous correlation by Delfour (1977) of the Hibshi formation of Bramkamp and others (1963) with his Hibshi Formation (fig. 2). The correlation was made (Delfour, 1977, p. 11-12) by projecting the base of the Jabal Hibshi reference section $110 \mathrm{~km}$ southwestward, through isolated inclusions in post-Murdama granite (Ar Rahadah batholith of Delfour, 1977), to a similar-facing section of coarse conglomerate at Jabal umm Sammah (fig. 1, 3).

The questions of what constitutes the Hibshi unit and what is the conglomerate at Jabal umm Sammah are answered by comparing the dissimilar clast assemblages, "basement" rock-types, and relations with Murdama sandstone in the two sections. Brosset and Delfour (1972), Delfour (1977), Greenégsta), and Cole (this report) concur that the thick, homoclinal section of conglomerate at Jabal umm Sammah grades up-section into Murdama sandstone. This conglomerate is deposited on altered diorite and tonalite (similar to rocks of the Suwaj suite) and contains abundant clasts of these

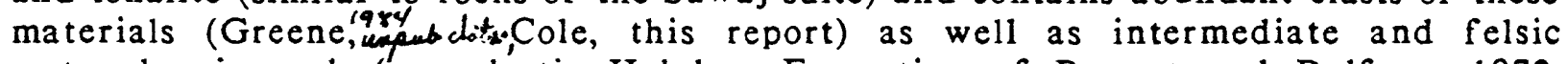
metavolcanic rock (pyroclastic Halaban Formation of Brosset and Delfour, 1972; Nuqrah Formation of the Hulayfah Group of Delfour, 1977). Based on stratigraphic position, lithology, and the absence of reported fresh volcanic-rock clasts, the conglomerate at Jabal umm Sammah clearly corresponds to the Timiriyat conglomerate.

The volcanic and volcaniclastic rocks in the excellent and well described section at Jabal Hibshi (Williams, 1983), contain fresh amphibole, and some plagioclase preserves delicate primary zoning and tubular forms (Cole, this report). The Hibshi formation of Williams (1983) rests on and contains boulders of biotite quartz diorite that is 650 Ma old (Cole and Hedge, 1984, unpub. data; approximately coeval with the end of Murdama deposition inferred in this report). Higher in the section, the Hibshi contains abundant clasts of Murdama sandstone and fresh volcanic rock (Williams, 1983). Therefore, the composition of the Hibshi formation of Williams (1983), the age of its substrate, the abundance of interbedded dacitic to rhyodacitic volcanic rocks (unknown from the Murdama group in the northeastern Shield; Greene, unfasia; Cole, this report), and the abundance of Murdama-sandstone clasts argue strongly that the Hibshi postdates the Murdama group. In all of these attributes, it is similar to the Jurdhawiyah group, and figure 2 indicates that correspondence. 
The Timiriyat conglomerate may also correspond in part with conglomerate mapped by du Brayimpns) in the Jabal as Silsilah quadrangle (fig. 1; not included on fig. 2). North of the Raha fault zone and structurally separated from the dominant sandstone unit of the Murdama group ("Maraghan lithic graywacke" of du Bray,inprese), coarse, poorly sorted, polymict conglomerate containing abundant clasts of 'graywacke", metavolcanic rock, minor limestone, and "mafic plutonic rock" is interbedded with pebbly sandstone. Together, these units appear to overlie metabasalt and metarhyolite (du Bray, in pnus; p. 8-9) that are intruded by weakly cataclastic and thoroughly recrystallized metadiorite (Cole, this report; lat $26^{\circ} 07^{\prime} \mathrm{N}$., long $42^{\circ} 44^{\prime}$ E.) that may correlate with the Suwaj suite. The conglomerate mapped by du Bray is also schistose and flattened near the Raha fault (fig. 1), analogous to deformation of the Timiriyat conglomerate between the Ata and Shara faults. Thus, the dominant lithology, apparent stratigraphic position, and similar structural style suggests a possible correspondence with the Timiriyat.

The limestone unit of the Murdama is less problematic because abundant, thick sections of calcareous rock are unknown from any other group in the northern Shield (Johnson, 1983a). As is the case in the Uqlat as Suqur quadrangle, limestone typically occupies the basal or near-basal position within the Murdama throughout its area of exposure (Greene, 1983; ${ }^{\prime 94}$ ). Murdama limestone is commonly intricately folded, disrupted, and variably recrystallized (Delfour, 1979; Cole, 1981, this report; Greene, 1983), most likely because the post-Murdama deformation of the depositional basins was concentrated on these ductile materials in contact with rigid Dhiran-Suwaj terrane. Limestone in the Murdama has locally been referred to as Farida marble (Bramkamp and others, 1963; Delfour, 1979, 1981; Greene, 1983), but the name is not used in this report because the reference locality is $200 \mathrm{~km}$ to the southeast and marble is an inappropriate term for these nonmetamorphosed rocks.

As a point of clarification, both Muller (1975) and Cole (1981) interpreted limestone to be the upper unit of the Murdama group (Jabal Kutayfah Formation of Muller) at Jabal Kitayfah in the Al Jurdhawiyah quadrangle (fig. 1), although it is overlain to the north by sandstone. A re-examination of clastic rocks beneath the limestone demonstrates that, in addition to minor Murdama sandstone, a conglomerate unit (mapped as "Jurdhawiyah volcanic conglomerate" by Cole, 1981) contains only altered volcanic and plutonic clasts, and thus probably correlates with the Timiriyat conglomerate. This re-assignment of the conglomerate is further consistent with its structural position above rocks of the Suwaj suite (biotite-hornblende tonalite of Cole, 1981) and beneath limestone that is, in turn, overlain by Murdama sandstone.

The formation-rank Sandstone unit of the Murdama group, as defined and used in this report, correlates by outcrop continuity with the Hadiyah formation as used by

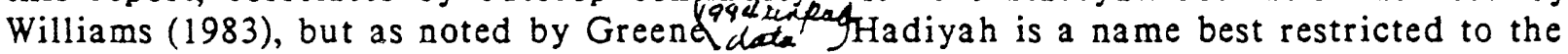
vicinity of its original definition (the Hadiyah station on the Hijaz railway in the northwestern part of the Shield; Brown and others, 1963a). The Sandstone unit also correlates by continuous outcrop in the Maraghan basin (fig. 3) with the Maraghan lithic graywacke of du Bray, enpusen. The Murdama formation, as used by Bramkamp and others (1963), Brown and others (1963b), and Brosset and Delfour (1972), includes all rock types within the Murdama group of this report, as well as rock that correlates with the Jurdhawiyah group (fig. 2). 
Layered rocks of the Jurdhawiyah group cover about 15 percent of the Uqlat as Suqur quadrangle and consist of andesitic flow rock, flow breccia, and tuff (primary volcanic deposits), and abundant volcaniclastic conglomerate and sandstone derived from these contemporaneous volcanic materials. This group is characterized by major facies changes over short lateral and stratigraphic intervals and was deposited in discrete epicontinental basins that were structurally active during volcanic activity. The Jurdhawiyah was deposited partly in shallow-water marine environments, and partly under subaerial conditions (Cole, 1981, 1984c).

Relics of two depositional basins are preserved in this quadrangle, and evidence presented in this report indicates deposition was not simultaneous in both. The Idayri basin (fig. 3 ) is the larger of the two and extends east and west across the entire southcentral portion of the quadrangle and into adjoining areas (Cole, 1984c). The smaller and younger Shuqrah basin is preserved in the extreme northwestern corner of the quadrangle (fig. 3) and extends a few kilometers west and north in adjoining areas (Cole, 1984c; Williams and Simonds, 1985).

The base of the Jurdhawiyah group is marked by a major erosional unconformity that truncates all pre-existing rock units. Southeast of this quadrangle, Cole (1981) noted that this surface locally preserves as much as $100 \mathrm{~m}$ of paleotopographic relief, but irregularities are much less pronounced in the Uqlat as Suqur quadrangle. Jurdhawiyah andesite southeast of Shaib adh Dhiran appears to be anomalously thick in a channel cut into the Dhiran meta-andesite, but the contact is not well exposed. The top of the Jurdhawiyah is largely removed by erosion, but an angular unconformity separates it from the Humaliyah formation $(5 \mathrm{~km}$ west of this quadrangle along the Jabal al Musayqir ridge; Cole, this report), and from Cambrian and Ordovician Saq Sandstone at Jabal Timiyah. The end of Jurdhawiyah deposition and volcanic activity is established by intrusions of the Idah suite (about $620 \mathrm{Ma}$ old; Cole and Hedge, 1984, unpub. data), but the absolute age of onset is presently undefined.

The formation-and member-rank sub-units of the Jurdhawiyah group vary widely in thickness along strike and do not define a well ordered stratigraphic progression from bottom to top, either within individual depositional basins or within individual sections (Cole, 1981, 1984c, this report). The sub-units are based on dominant and internally uniform lithologic traits and on their practical utility as mappable entities. The four formation-rank units are Andesite, Volcaniclastic conglomerate, Volcaniclastic sandstone, and Shara conglomerate. Two volumetrically minor but lithologically distinct units are defined as the Polymict conglomerate member and the Lapilli tuff member; these units are typically interbedded with Volcaniclastic conglomerate and Volcaniclastic sandstone, respectively, although they are locally interlayered with other units as well.

The order of description of these units is based on general tendencies in the order of deposition within the various basins as noted in this quadrangle and surrounding areas (Cole, 1981, 1984c). The Andesite unit typically occupies a basal or near-basal position within the group. The Volcaniclastic conglomerate unit is also typical of the lower parts of the group, as is the Polymict conglomerate member. Volcaniclastic sandstone and the Lapilli tuff member are present in all apparent stratigraphic positions in the group, but are typically thickest and most continuous above the Andesite and Volcaniclastic conglomerate units. The Shara conglomerate is described last because it clearly occupies a position above a minor angular unconformity in the northern part of the Idayri basin, and represents the youngest preserved Jurdhawiyah formation. 


\section{Andesite}

No more than 15 percent of the Jurdhawiyah outcrop in the Uqlat as Suqur quadrangle consists of andesitic flow rock and flow breccia (Ja) that are defined as the Andesite unit. The composition of the unit is based on phenocryst mineralogy and on major-element chemical data from this and adjacent quadrangles (Cole, 1982, 1984b). The thickest section forms the base of the group at the eastern border of the quadrangle southeast of Shaib adh Dhiran, but fresher and less brecciated andesite crops out along the southern margin of the Idayri basin between Jibal ash Shuhban and Jabal al Habla. Small and discontinuous layers of primary volcanic rock are locally interbedded with the Volcaniclastic conglomerate unit, but are too small to indicate on the map.

The andesite is largely structureless on the scale of several hundred meters, but relict bedding can locally be inferred in outcrop from the distribution of amygdules and from contacts between brecciated and non-brecciated flow rock. Brecciated flow rock makes up about three-fourths of the unit and consists of angular and irregular fragments of texturally varied andesite in an igneous andesite matrix. The outcrop and petrographic distinction between flow breccia (deposited at high temperature) and volcaniclastic conglomerate (deposited at lower temperature) is difficult (Fisher, 1961, 1966), and breccia was mapped conservatively (only where clear igneous-matrix textures are present). This approach under-represents the volume of the Andesite unit on the map, and additional flow breccia is probably contained in the Volcaniclastic conglomerate unit.

Most rocks of the Andesite unit weather to dark-brown and green-brown colors, and thick desert varnish is characteristic. Typical Jurdhawiyah andesite (flow rock and fragments in flow breccia) is porphyritic and contains about 5 to 25 percent phenocrysts that are distinct in hand specimen and on weathered surfaces. Phenocrysts range from several millimeters to as much as a centimeter in diameter, and assemblages typically include plagioclase and magnetite with augite, hornblende, or both. Hornblende andesite (without plagioclase phenocrysts) is locally common, and a few mafic andesites contain minor hypersthene as a phenocryst (Cole, 1982, 1984b). Dacite is rare in this quadrangle (lat $25^{\circ} 42^{\prime} \mathrm{N}$., long $42^{\circ} 30^{\prime} \mathrm{E}$.) but more common in adjoining

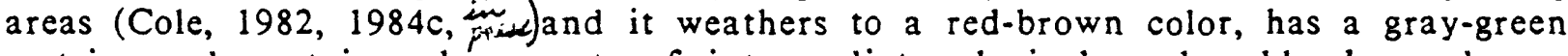
matrix, and contains phenocrysts of intermediate plagioclase, hornblende, and rare quartz.

Typical plagioclase phenocrysts in andesite are equant to tabular and consist of zoned labradorite-andesine; in many samples, these crystals enclose lobate and irregular patches of devitrified glass (relict melt). Augite is characteristically fresh, euhedral, nearly colorless, and simply twinned on $\{100\}$. Hornblende varies between samples from deep red-brown to deep green-brown, commonly has a narrow reaction rim of granular magnetite and pyroxene(?), and is markedly zoned in some samples. Fresh hypersthene is rare, but forms small, euhedral crystals that are pleochroic from pale green to pale pink. Magnetite characteristically forms small, euhedral octahedrons.

The dark-green matrix of the andesite consists chiefly of feldspar laths (commonly with a moderate to strong trachytic alignment), fine-grained augite and(or) hornblende, granular opaque minerals, and a fine-grained mesostasis. Relict forms of pyroclastic fragments are locally preserved and are identified by trains of fine-grained oxides and variations in grainsize of the groundmass constituents. Relict vesicles are typically spherical and undistorted by flow or compaction. 
All of the Jurdhawiyah volcanic rocks are altered to some degree, although primary textures and most phenocryst minerals are preserved throughout the unit. Plagioclase phenocrysts are partially replaced by calcite and saussurite, hornblende phenocrysts are locally converted to chlorite or actinolitic amphibole, and pyroxene phenocrysts are replaced by bastite or actinolitic amphibole (plus chlorite), depending on original composition. Much of the mesostasis has recrystallized to epidote, chlorite, granular sphene, and some quartz, and is locally replaced by calcite. Vesicles are typically filled by concentric layers of quartz, epidote, and chlorite, and sparry calcite or weakly birefringent andradite garnet locally fills the central void.

\section{Volcaniclastic conglomerate}

The dominant unit of the Jurdhawiyah group, regionally and in the Uqlat as Suqur quadrangle, consists of coarse-grained, poorly sorted, indistinctly bedded conglomerate (Jc) whose clasts are chiefly composed of textural varieties of andesitic volcanic rock. These coarse, fragmental deposits appear to have been dominantly transported by epigene agents (mass wasting, mudflow, lahar, stream flow), but the possibility of fragmentation and transport by volcanic processes cannot be ruled out in all cases. The unit is characterized by wide variations in the clast size, sorting, angularity, and composition, and by variable bedforms. On the basis of dominant clast size and local evidence for pyroclastic versus epiclastic fragmentation, various depositional units would be called epiclastic volcanic breccia, epiclastic volcanic conglomerate, pyroclastic breccia, or lapillistone (Fisher, 1961, 1966). It was not possible to map these distinctions during reconnaissance, and so the more general and encompassing term "volcaniclastic conglomerate" (Fisher, 1966, p. 289) is used.

The Volcaniclastic conglomerate unit comprises most of the rocks in the Shuqrah basin and forms an exceptionally thick deposit along the southern margin of the Idayri basin (fig. 3). It generally forms the basal unit of the Jurdhawiyah group in these localities and rests directly on rocks of the Murdama group. Volcaniclastic conglomerate is interbedded with and grades laterally into the Volcaniclastic sandstone unit, particularly in the northern and western parts of the Idayri basin, and is locally interbedded with the Andesite unit along the southern margin of the basin.

The unit typically crops out in low linear ridges and hills; first- and second-order drainage channels form a dendritic network due to the structural homogeneity of coarse conglomerate, but higher-order channels follow the general trace of bedding. Outcrop quality is variable (depending on cementation and average clast size), but most of the unit weathers to a rubble of disaggregated cobbles and boulders.

Bedding is weakly defined by variations in clast size and degree of sorting. Layers composed of coarser clasts are typically more resistant to erosion than cobble and pebble conglomerate, and produce a weak ledge-and-ridge morphology at the outcrop scale. Individual beds are traceable for tens and locally hundreds of meters and maintain a fairly constant thickness of about a few meters along strike. Scour channels and cut-and-fill structures are locally present, but are not as common as subparallel bedding. Nevertheless, layers that are 10 to $20 \mathrm{~m}$ thick and appear homogeneous are probably composed of overlapping channel-type bedforms. Lensoid bodies of well-bedded sandstone, typically 10 to $40 \mathrm{~cm}$ thick and traceable for several meters along strike, are widespread within conglomerate and provide the most reliable measure of bedding orientation. 
The Volcaniclastic conglomerate unit has a clast-supported structure and is dominated by cobbles and boulders, but clast size grades continuously to medium sand in the matrix. Most clasts range between about 5 and $20 \mathrm{~cm}$ in diameter, although boulders as large as $80 \mathrm{~cm}$ are not uncommon. In coarse boulder beds, the average clast diameter is on the order of $40 \mathrm{~cm}$, and clasts in excess of one meter diameter are locally present. Sorting is generally poor, although individual beds have a dominant clast size and a characteristic maximum clast size. Large boulders are generally rounded, clasts larger than $20 \mathrm{~cm}$ diameter are sub-rounded, and sub-20-cm material is variably sub-rounded, sub-angular, or angular.

The Jurdhawiyah-group volcaniclastic conglomerate is distinguished from all other conglomerates in the region by its simple andesite-clast assemblage. At any given outcrop, several textural varieties are present that typically include porphyritic (plagioclase, hornblende, and(or) pyroxene phenocrysts), aphanitic, amygdaloidal, and(or) fragmental types. These materials are mineralogically and texturally equivalent to rocks in the Andesite unit, the Lapilli tuff member, and the Plagioclase porphyry (intrusive-rock) unit. Clast color is generally green or brown, although tuff and some porphyry clasts are characteristically red-brown or orange-brown.

Alteration of the volcaniclastic conglomerate is difficult to distinguish from source-area alteration, but the finer matrix is cemented by chlorite, epidote, calcite, and minor quartz. Most alteration probably took place in the source areas because conglomerate commonly contains clasts of similar bulk composition that range from very fresh to extensively altered.

Regional variations in the conglomerate unit are reflected by local admixtures of other clast material. Along the margin of the Shuqrah basin and the southern margin of the Idayri basin, Murdama sandstone clasts make up as much as 10 percent of the rock. Volcaniclastic conglomerate in the vicinity of $25^{\circ} 33^{\prime}$ N., $42^{\circ} 28^{\prime}$ E. contains a few clasts of Murdama limestone and is densely cemented and replaced by calcite. Scattered clasts of Dhiran meta-andesite and sodic metadacite and Suwaj suite plutonic rocks are present southeast of Shaib adh Dhiran.

Polvmict conglomerate member.--Conglomerate beds with more than about 25 percent cobbles and boulders of pre-Jurdhawiyah rock are defined as the Polymict conglomerate member. The member is mapped in only one locality in this quadrangle, but similar beds in a similar stratigraphic context are recognized in many places near the base of the Jurdhawiyah group (Cole, 1981, 1984c).

The Polymict conglomerate member crops out in this quadrangle for about $4 \mathrm{~km}$ along strike at lat $25^{\circ} 40^{\prime} \mathrm{N}$., long $42^{\circ} 29^{\prime} \mathrm{E}$., near the top of a Volcaniclastic sandstone unit and about $1000 \mathrm{~m}$ above the unconformable base of the Jurdhawiyah group. The member is overlain by a prominent red-brown lapilli tuff that is moderately welded and indicates probable subaerial deposition. Thickness of the polymict conglomerate is variable along strike, but is typically 20 to $30 \mathrm{~m}$ thick in the eastern outcrops. Farther northwest, the stratigraphic position is not clear and the polymict conglomerate beds appear to transgress across the Volcaniclastic sandstone unit.

The pre-Jurdhawiyah clasts at this locality are derived from the Dhiran-Suwaj terrane, make up about 30 percent of the conglomerate, and consist chiefly of altered, leucocratic granodiorite granophyre and schistose sodic metadacite. Other exotic clast types include strongly altered, epidote-rich meta-andesite, diorite, and microdiorite. The remaining 70 percent of the cobbles consist of Jurdhawiyah andesite and plagioclase porphyry. 


\section{Volcaniclastic sandstone}

About 40 percent of the outcrop area of the Jurdhawiyah group in this quadrangle consists of medium- to coarse-grained sandstone ( $\mathrm{J}_{\mathrm{S}}$ ), pebbly sandstone, and minor intercalated volcaniclastic conglomerate. It is most widely exposed in the northern and western parts of the Idayri basin (fig. 3), where it may be more than $5 \mathrm{~km}$ thick, but it is generally much thinner, highly variable across and along strike, and no. estimate of characteristic thickness is meaningful.

In the Shuqrah basin (fig. 3), the Volcaniclastic sandstone unit forms the local base of the Jurdhawiyah group and is probably no more than $200 \mathrm{~m}$ thick. In the Idayri basin, sandstone is also the local basal unit, but it is widely interlayered with the Volcaniclastic conglomerate unit in the east-central part of the basin and becomes the dominant rock type in the western (stratigraphically highest) part of the basin. Thus, the Volcaniclastic sandstone unit does not occupy a simple, time-bounded position within the Jurdhawiyah group.

The Volcaniclastic sandstone unit is less resistant to erosion than the other Jurdhawiyah units, but its more uniform bedding characteristics produce a welldeveloped trellis drainage pattern. Typical beds are 5 to $20 \mathrm{~cm}$ thick (maximum $100 \mathrm{~cm}$ ) and internally uniform, although millimeter-scale laminations are locally present. Facing direction is most commonly determined from minor cut-and-fill structures, load casts, ripped-up siltstone layers, and from short-wavelength, low-amplitude crossbedding, although the latter is not common. Graded beds are rare, as are raindrop imprints (common in adjoining areas on the tops of tuffaceous siltstone beds; Cole, 1981, 1984c; Williams, 1983), which are limited to the eastern part of the Idayri basin.

Bedding is generally parallel and continuous for hundreds of meters along strike, and conformable with bedding in adjacent Jurdhawiyah units. In the north-central part of the Idayri basin, however, an angular discordance within the Volcaniclastic sandstone unit is outlined by traces of bedding between the villages of Al Ifayhid and Dawbah (pl. 1). The beds south of the discordance dip about $15^{\circ}$ less than those to the north and the section is not folded; the lower beds appear to be truncated along a minor intraformational unconformity (cross-section A-A'; pl. 1).

Most of the sandstone is pale green to pale brown, coarse- to medium-grained, and moderately to poorly sorted. Sand-sized fragments are very irregular and angular and are typically green, although 10 to 15 percent are red or brown; detrital quartz and plutonic rock fragments are very rare, except in areas noted below. Granule and pebble conglomerate layers are common, and fine sandstone beds are present but not typical. Lenses of cobble conglomerate, generally, about one meter thick and exposed for several tens of meters along strike, make up less than 20 percent of any local section. Numerous thin and continuous beds of red lapilli tuff are bedded with the sandstone, particularly in the western part of the Idayri basin, and they are described separately below as the Lapilli tuff member.

The composition of sand grains is simple and consists of the same rock types listed for the Volcaniclastic conglomerate unit. The sandstone also contains about 10 percent detrital plagioclase and 5 to 15 percent detrital hornblende and(or) pyroxene derived from disaggregation of the porphyritic volcanic rocks. Cement and alteration minerals consist of nonoriented chlorite, granular epidote and sphene, and minor calcite. Classification on the basis of sorting and clast composition is expressed as (Folk, 1968): immature to submature andesite arenite and feldspathic andesite arenite. 
The only significant variation in the Volcaniclastic sandstone unit is associated with the northern margin of the Idayri basin, where detrital quartz and clasts of fine-grained Murdama sandstone make up as much as 20 percent of the rock. Both schistose and nonschistose Murdama sandstones are present, and much of the quartz resembles post-Murdama vein quartz (identified by characteristic granular chlorite and sparry calcite) that is widespread in the Ata-Shara block (fig. 3) to the north. These factors indicate that the metamorphosed, veined, and deformed rocks in the Ata-Shara block were exposed in the Jurdhawiyah source terrane during late deposition in the western Idayri basin.

Lapilli tuff member.--Thin sheets of red, orange, and red-brown pyroclastic tuff (Jt and $-v-)$ in the Jurdhawiyah group are defined as the Lapilli tuff member; they have been mapped at several stratigraphic positions in both depositional basins in this quadrangle, and do not form a time-bounded unit. The thickest deposits (about $100 \mathrm{~m}$ ) form two tuff sheets near the base of the Shuqrah basin (fig. 3). To the west but still within this basin, Brosset and Delfour (1972) report that the uppermost exposed unit, possibly several hundred meters thick, consists of "rhyolite ignimbrite, tuff, and rhyolite breccia" which, except for compositional nomenclature, is equivalent to the Lapilli tuff member (Cole, this report). In the Idayri basin, the Lapilli tuff member is represented by sheets on the order of 5 to $10 \mathrm{~m}$ thick that are interbedded with volcaniclastic sandstone and, rarely, with conglomerate. Most of these tuff beds crop out near the center of the syncline west of Wadi ash Shabah, which implies they were erupted during the latter stages of Jurdhawiyah sedimentation and volcanic activity in that basin.

Although thin, beds of lapilli tuff are continuous for several kilometers along strike and form useful marker units. They are distinguished in outcrop by red-orange, red-brown, and gray colors, and by flattened and deformed volcanic lapilli, blocks, and ash. Following Fisher (1961), the term lapilli tuff is used to denote the dominance of ash-sized pyroclasts and a characteristic admixture of 10 to 30 percent lapilli-sized fragments. Phenocrysts, most commonly plagioclase, typically form about 10 to as much as 20 percent of the rock.

Composition of the Lapilli tuff member is variable across the quadrangle; as inferred from the composition and proportions of phenocrysts. No tuff was chemically analyzed because of the high proportion of phenocrysts, the common presence of secondary silica and clay in relict gas cavities, and variable amounts of accidental rock fragments (including andesite, sandstone, schistose sandstone, and strained quartz). The dominant phenocryst is andesine, magnetite is second in abundance, and accompanying phenocrysts include augite, augite+brown hornblende (rare), biotite, or biotite+sanidinetquartz (rare). Pyroxene-bearing tuffs were probably produced by eruption of andesitic magma, whereas biotite-bearing tuffs suggest dacitic-rhyodacitic magma.

The composition and distribution of these tuffs have not been adequately studied but, some generalizations are apparent from this reconnaissance. Andesite tuff is chiefly limited to the south-central Idayri basin (near Al Maylih), where it is commonly interbedded with dacite tuff. In the higher (stratigraphic) part of the Idayri basin west of Wadi ash Shabah, andesite is rare, dacite is dominant, and the most felsic tuffs (containing quartz and some sanidine phenocrysts) are limited to the highest stratigraphic beds. All tuff in the Shuqrah basin is dacitic or possibly rhyodacitic (oligoclase, sanidine, biotite, magnetite, and quartz phenocrysts). As the product of pyroclastic eruptions, some beds of the Lapilli tuff member were probably deposited simultaneously in the Idayri and Shuqrah basins, and a detailed study of mineralogy and depositional order of the beds could establish the temporal relation between Jurdhawiyah deposition in the two basins. 
Plagioclase phenocrysts are generally tabular, weakly normally zoned, and not embayed. Biotite and magnetite are typically euhedral and appear to have been in equilibrium with the melt, but phenocrystic quartz is not an equilibrium phase (typically embayed and bordered by a reaction rim). The extent of welding and flattening of pyroclasts is variable, but most samples from thin tuff sheets are moderately welded. Denser welding is more typical of thicker sheets in the Shuqrah basin, and flattened shards and pumice form a pervasive parallel fabric.

Post-depositional alteration (other than general devitrification) is variable and does not correlate with tuff composition, geographic region, or stratigraphic position. About one-third of the tuff samples are essentially unaltered, but in the remainder, plagioclase is variably altered to saussurite, augite to bastite, and biotite to granular oxide minerals and epidote(?). The matrix is commonly replaced by chlorite, calcite, and clay(?) minerals.

\section{Shara conglomerate}

The Shara conglomerate (JSc) of the Jurdhawiyah group is defined in this report for loosely cemented, weakly bedded polymict conglomerate that crops out only in the north-central part of the Idayri basin, south of Shaib umm Shara (fig. 3; pl. 1). The Shara was deposited above a minor intra-basinal unconformity, and is the youngest preserved unit of the Jurdhawiyah group. Outcrops are characteristically poor, but the planar base of the Shara at lat $25^{\circ} 41^{\prime} 43^{\prime \prime} \mathrm{N}$., long $42^{\circ} 11^{\prime} 40^{\prime \prime}$ E. dips gently southward over folded, calcareous Murdama sandstone, and sparse interbedded sandstone at the summit of Jabal al Idayri dips $10^{\circ}$ due south. The calculated preserved thickness of the Shara conglomerate is therefore no more than about $150 \mathrm{~m}$. The base is not exposed south of Jabal al Idayri, but is inferred on structural grounds to overlie tilted beds of older Jurdhawiyah units.

The Shara conglomerate is distinguished by its red-brown color, weak lithification, and unique clast assemblage that consists chiefly of deformed cobbles and boulders derived from the schistose Timiriyat conglomerate (Murdama group) north of the Shara fault. These clasts were deformed prior to deposition in the Shara because their major ellipsoid-axes are not aligned, and some clasts retain selvages of schistose sandstone matrix from the Timiriyat conglomerate. Other clasts in the Shara include schistose and nonschistose Murdama sandstone, phyllite, vein quartz (similar to veins in the Ata-Shara block), brown limestone/marble, felsic volcanic rock, Jurdhawiyah volcaniclastic sandstone, and less than about 20 percent Jurdhawiyah volcanic rocks.

Most clasts in the Shara are red or brown, even though the source rocks are characteristically green, and the Murdama beneath the conglomerate is also atypically red-brown. These observations suggest the source terranes were exposed to oxidizing atmosphere (in a nonmarine environment) at the time of erosion and transportation. Shara deposition is inferred to have been rapid and chaotic from the size and irregularity of the clasts, extremely poor sorting, and nearly complete lack of bedding or grading. Many clasts recycled from the Timiriyat conglomerate are fragile and can only have been transported short distances, because they were fractured and veined prior to erosion.

Sparse cement consists of disseminated hematite, granular calcite, and minor epidote. Localized hydrothermal alteration was noted at two localities adjacent to plugs of sodic microsyenite (lat $25^{\circ} 39^{\prime} 27^{\prime \prime} \mathrm{N}$., long $42^{\circ} 16^{\prime} 46^{\prime \prime} \mathrm{E}$; and lat $25^{\circ} 41^{\prime} 37^{\prime \prime} \mathrm{N}$., long $42^{\circ} 23^{\prime} 07^{\prime \prime}$ E.). Margins of the clasts are lightly replaced by granular epidote and spongy calcite, and matrix voids are filled with epidote crystals, euhedral andradite garnet crystals ( 0.5 to $2.0 \mathrm{~mm}$ in diameter), and coarse sparry calcite. The Shara is also 
locally cemented by brown and ocherous carbonate minerals along weak, west-trending fracture zones. Elevated values of barium and strontium are associated with the fracture zones, but no anomalous metal values were detected from these sites or from the hydrothermal-alteration localities (Cole, 1984b).

\section{Correlation and nomenclature}

The rocks of the Jurdhawiyah group were first defined southeast of the Uqlat as Suqur quadrangle as the Al Jurdhawiyah Formation of Muller (1975), although he misinterpreted their stratigraphic position and erroneously correlated them with the Murdama group. Cole (1981) redefined this assemblage as the (Al) Jurdhawiyah group and established that it overlies the Murdama group above a regional unconformity (fig. 2). The lack of definition and recognition of the stratigraphic position of the Jurdhawiyah group resulted in the assignment (prior to 1980) of most andesitic volcanic rocks to the Halaban/Hulayfah groups, the assignment of "rhyolitic" (red) volcanic rocks to the Shammar formation/group, and the assignment to clastic and carbonate rocks to the Murdama formation/group (fig. 2 references; Schmidt and others, 1979; Schmidt and Brown, inpmes; Greenwood and others, 1982).

The deposits of the Jurdhawiyah group are a distinct assemblage in the northeastern Shield that record voluminous post-Murdama calc-alkaline volcanic activity associated with the formation of fault-bounded epicontinental basins. Each of the four recognized basins (two of which are defined in this quadrangle) is marked by a major basal unconformity (Cole, 1981, 1984c), local wedges of coarse clastic debris derived from older terranes (Polymict conglomerate member), hornblende- and pyroxene-bearing intermediate volcanic rock (Andesite unit and Lapilli tuff member), and abundant coarse sediment (Volcaniclastic conglomerate and sandstone units) derived from erosion of contemporaneous volcanic piles (Cole, this report). Jurdhawiyah deposition is characterized by major facies changes and overlapping, lensoid bedding units that suggest rapid deposition in structurally active basins, and welded tuff beds and sedimentary structures indicate subaerial or shallow-water depositional environments.

These characteristics contrast markedly with the Murdama group, which chiefly consists of sediment derived from an older, metamorphosed (Dhiran-Suwaj) terrane deposited in deep-water marine basins (Cole, this report). The structural setting of Murdama deposition was typically quiescent (except near basin margins where Timiriyat conglomerate was deposited), and no significant contemporaneous volcanic activity is associated with the Murdama (Cole, 1981, 1984c, this report; Greene, 1983, 1984 ; Pellaton, 1984b).

atear

Some rocks in adjoining quadrangles were previously included (fig. 2) with the Halaban formation (Bramkamp and others, 1963) and the Murdama formation/group (Brown and others, 1963b; Bramkamp and others, 1963; Brosset and Delfour, 1972; Muller, 1975; Delfour, 1977), but are interpreted in this report to contain the essential characteristics of the Jurdhawiyah group. Partial correspondences (fig. 2) with the Shammar Rhyolite (Brown and others, 1963b; Bramkamp and others, 1963) the Shammar Rhyolite Formation (Brosset and Delfour, 1972), or the Malha Formation of the Shammar Group (Delfour, 1977) refer to dacitic (and rhyodacitic?) volcanic rocks, chicfly in the Shuqrah basin, that are defined in this report as the Lapilli tuff member of the Jurdhawiyah group. 
The Hibshi formation of Brown and others (1963b), Bramkamp and others (1963), and Williams (1983) between Jabal Hibshi and Wadi ar Rumah near lat $26^{\circ} 02^{\prime} \mathrm{N}$., long $41^{\circ} 45^{\prime} \mathrm{E}$. (fig. 1) is interpreted to correspond with the Jurdhawiyah group on the basis of its similar structural and depositional setting, composition and assemblage of its clastic and contemporaneous intermediate volcanic rocks, and its limited deformation and alteration relative to the Murdama group (Williams, 1983; Cole, this report). The Jurdhawiyah and Hibshi units cannot be strictly correlated however, because deposition in the "Hibshi basin" probably was not synchronous with Jurdhawiyah deposition in the Shuqrah basin, the Idayri basin, or the other localized, volcanically active depositional basins.

Deposition of the Hibshi formation of Williams (1983) is tightly bracketed between $650 \mathrm{Ma}$ and $621 \mathrm{Ma}$, and dacite was extruded in the upper Hibshi $632 \mathrm{Ma}$ ago (Cole and Hedge, 1984, unpub. data). Deposition of the Murdama and Jurdhawiyah groups is only bracketed between $680 \mathrm{Ma}$ and $620 \mathrm{Ma}$, but the Murdama is interpreted on regional evidence to be about $670 \mathrm{Ma}$ to $650 \mathrm{Ma}$ old, and the Jurdhawiyah to be about $640 \mathrm{Ma}$ to $620 \mathrm{Ma}$ old (Cole and Hedge, 1984, unpub. data). Thus, correlation of the Hibshi formation of Williams (1983) with the Murdama group (Williams, 1983; Greene, 1984 2ueblate) is considered invalid. The extension of the Hibshi formation name southwest to the conglomerate at Jabal umm Sammah (fig. 1) by Delfour (1977) is not supported by the evidence in the two areas, and the use of this term for the basal conglomerate of the Murdama group (Delfour, 1977, 1979; Williams, 1983; Greene, mpetst) is also considered invalid; the basal unit of the Murdama is defined in this feport as the Timiriyat conglomerate.

\section{HUMALIYAH FORMATION}

The youngest Proterozoic layered rocks of the Uqlat as Suqur quadrangle crop out in two small fault-bounded blocks on the Jabal al Musayqir ridge north of Shaib al Humaliyah, and are defined in this report as the Humaliyah formation. The Humaliyah has a basal member of rhyolite pyroclastic breccia and crystal tuff (approximately $60 \mathrm{~m}$ thick) and an upper member of crystal-rich rhyolite flow rock (more than $25 \mathrm{~m}$ thick). The base of the formation is generally covered by scree, but it unconformably overlies the Murdama group in this quadrangle and the Jurdhawiyah group in the adjoining quadrangle to the west (Cole, this report). The top of the Humaliyah is eroded and truncated by the Shara fault.

\section{Tuff-breccia member}

The lower part of the Humaliyah formation is defined as the Tuff-breccia member (ht) for pyroclastic rocks that form the lower slope of two northward-tilted fault blocks at Jabal al Musayqir. The lowest outcrops are red-orange and consist of about $50 \mathrm{~m}$ of coarse-grained fragmental pyroclastic breccia, overlain by about $10 \mathrm{~m}$ of well-bedded lapilli-crystal tuff. The pyroclastic breccia consists of angular ash, lapilli, and blocks of crystal-rich rhyolite (Cole, 1984b), and more than 70 percent accidental rock fragments (chiefly plagioclase-porphyritic dacite or rhyodacite and fine-grained Murdama sandstone). Pyroclastic breccia resembles conglomerate because of the high proportion of accidental clasts, but the rhyolite fragments are extremely irregular and locally molded around other fragments, and must have been emplaced at high temperature. 
The thickness of the lapilli-crystal tuff is variable but generally increases from about $10 \mathrm{~m}$ at the eastern end of the Jabal al Musayqir ridge to as much as $20 \mathrm{~m}$ in the adjoining quadrangle at the western ridge end (Cole, this report). The tuff is dark red and contains about 15 percent red-brown lapilli that are flattened parallel to bedding and to a weak but pervasive banded groundmass fabric. Phenocrysts of quartz and sanidine are typically about 2 to $4 \mathrm{~mm}$ in diameter and make up about 20 percent of the rock. Quartz forms euhedral (nonembayed) bipyramids that are about twice as abundant as sanidine phenocrysts; the latter are slightly rounded and encapsulated in fine-grained granophyre that merges with the groundmass. Rare crystals of very sodic plagioclase are embayed, and euhedral zircon and apatite are clustered in hematite-stained patches that probably mark the sites of former mafic grains.

The groundmass of the lapilli-crystal tuff is generally recrystallized to granular quartz and porphyroblastic to granophyric feldspar, but is faintly banded and contains hematite-stained ghosts of former shards. Welding is moderate (slightly flattened lapilli) and appears to be uniform from bottom to top at the eastern end of the ridge. However, a slight topographic bench near the middle of the 20 -m-thick section at the western ridge end may indicate two flow or cooling units.

\section{Rhyolite member}

The upper part of the Humaliyah formation consists of dense, structureless, crystalrich rhyolite defined as the Rhyolite member (hry) that rests conformably on the Tuff-breccia member. This member is only exposed on the northern fault block and its top is covered by scree; the absence of outcrop northward to the Shara fault may indicate that softer Humaliyah rock (not exposed) is present above the rhyolite, but has not been confirmed.

The rhyolite is orange-red in outcrop (maroon on fresh surfaces) and resembles the underlying lapilli-crystal tuff in composition and general appearance, but it lacks the lapilli and planar fabric and contains more phenocrysts (about 35 percent on the average). Quartz phenocrysts are equant, slightly embayed, and about 3 to $4 \mathrm{~mm}$ in diameter. Sanidine and minor albite are euhedral to slightly rounded, and typically occur together in glomerophenocrysts, 3 to $6 \mathrm{~mm}$ in diameter. Coarse, 2-mm zoned zircon crystals and apatite needles are present throughout the rock, but mafic grains are not preserved.

The groundmass of the rhyolite consists of a granular quartz and abundant finegrained hematite intergrown with optically continuous patches of feldspar. Miarolitic cavities are common and lined with mosaics of zoned quartz. Post-emplacement alteration is limited to partial replacement of feldspar by fine-grained sericite and granular carbonate, leaching and replacement of mafic grains by hematite, and recrystallization of the groundmass with widespread hematite.

\section{Correlation and nomenclature}

The Humaliyah formation is the only Proterozoic, post-Jurdhawiyah layered unit in the Uqlat as Suqur quadrangle, and is probably only preserved here because of postHumaliyah movement on the Shara fault. The Samra rhyolite $100 \mathrm{~km}$ to the east near An Nabhaniyah (fig. 1) was emplaced at the same time (Cole, 1984c), but most rocks of similar age, composition, and geologic setting have largely been removed by erosion. 
The volcanic rocks of the Humaliyah formation are weakly peralkaline (Cole, $1984 \mathrm{~b}$ ) and may have been erupted from a source $19 \mathrm{~km}$ to the west marked by a peralkaline ring-dike at Jabal Daym (Brosset and Delfour, 1972), which is located on a western branch of the Shara fault (Cole, this report). In the northeastern Shield north of the Halaban-Zarghat fault (fig. 1), peralkaline granite was only emplaced during a brief interval from about $585 \mathrm{Ma}$ to $570 \mathrm{Ma}$ ago (Stuckless and others, 1982a; Stuckless and others, inpraw; Cole and Hedge, 1984, unpub. data), and it is probable that the Humaliyah formation was extruded at this time. Figure 2 indicates partial correspondences between the Humaliyah and rocks mapped as Shammar rhyolite (Brown and others, 1963b; Bramkamp and others, 1963; Brosset and Delfour, 1972) or as Malha Formation of the Shammar Group (Delfour, 1977) because all are described as silica-rich volcanic rocks that are largely undeformed, locally associated with peralkaline granite, and younger than all other regional layered units.

\section{SAQ SANDSTONE}

The mesa at Jabal Timiyah (western border of this quadrangle) has a flat summit because it is capped by a 130-m-thick section of resistant, buff sandstone that is correlated with the Cambrian and Ordovician Saq Sandstone (OEs) of Powers and others (1966). Although Jabal Timiyah is more than $150 \mathrm{~km}$ west of the nearest Saq outcrops on the eastern margin of the Arabian Shield, the correlation can be made with confidence on the basis of the uniform and distinctive quartz-rich and cross-bedded character of the formation. The Saq Sandstone is at least $600 \mathrm{~m}$ thick in the type area at Jabal Saq (fig. 1), increases to as much as $850 \mathrm{~m}$ near the Jordan-Saudi Arabia border, and is truncated by a Permian erosion surface south of the type area (Powers and others, 1966, p. D21). Fossils are rare in the Saq but its minimum age is well defined by excellent Early Ordovician graptolite fossils in the lower part of the conformably overlying Tabuk Formation (Powers, 1966, p. D25; D. Vaslet, oral commun, 1984).

Vertical cliffs at Jabal Timiyah provide excellent (although largely inaccessable) exposures of the Saq, but the formation can be examined on the summit and in two landslide blocks ( 30 to $40 \mathrm{~m}$ thick) on the north slope of the mountain. The regional unconformity surface at the base of the $S a q$ is subhorizontal and largely planar, although it preserves as much as $20 \mathrm{~m}$ of local paleotopographic relief. Jurdhawiyah sandstone beneath this surface is slightly oxidized but otherwise unweathered. The lowermost $2 \mathrm{~m}$ of the Sandstone are not typically conglomeratic, but contain rare cobbles and pebbles of Jurdhawiyah. In contrast to the sandstone above, the lower 5 to $10 \mathrm{~m}$ section is weakly cemented and friable, indistinctly bedded, and locally stained bright orange-red in irregular zones near (but not on) the unconformity.

Bedding in the Saq consists of 5- to $15-\mathrm{m}$ thick, lensoid, internally crossbedded sets. Millimeter- to centimeter-scale laminations are defined by variations in grain size, proportion of relict detrital feldspar, iron staining, and green detrital grains. Crossbedding is chiefly defined by plane-bedded laminae, but arcuate (festoon) beds are also common within some intervals. Most of the sand is medium to coarse grained, and clasts are subrounded to moderately well rounded, and weakly to moderately sorted. Pebbles of quartz, as large as $2 \mathrm{~cm}$ in diameter, are rare and are dispersed in the rock rather than concentrated in beds. 
More than 90 percent of the detrital grains are quartz, of which one-third are monocrystalline and two-thirds are multidomain, undulose aggregates. Feldspar is inferred to comprise the remaining 10 percent of the clasts from rare microcline and illite-montmorillonite clay aggregates. Detrital heavy minerals are not common but include (in decreasing order of abundance) green tourmaline, zircon, magnetite, ilmenite(?; altered to leucoxene), muscovite, monazite, and apatite. Coarse sand grains (larger than $0.3 \mathrm{~mm}$ in diameter) are distinctly more rounded than fine sand $(0.1$ to 0.15 $\mathrm{mm}$ ), and the heavy minerals tourmaline, muscovite, and apatite are typically more rounded than zircon, monazite, and magnetite. These textural features indicate that sedimentary rocks were a significant part of the source terrane for the Saq.

Secondary overgrowths on detrital quartz grains form the chief cement in the unit. Feldspar grains were probably replaced by clay minerals at the same time secondary silica was deposited, because both clay aggregates and quartz overgrowths are coated by later hematite. This brick-red to black, iron cement is a widespread and distinctive feature of the Saq and is typically concentrated along joints, along curved and sinuous "roll-front" surfaces, and locally along porous bedded zones. The density of the hematite cement increases toward joints and "roll-front" surfaces, and its deposition was probably controlled by oxidation-reduction reactions in pore water. Granular carbonate minerals were deposited at a later time, but they (along with clay minerals derived from feldspar) have been variably leached from the rock.

The surface of Jabal Timiyah is littered with very well rounded pebbles and cobbles of quartz. These clasts might represent the residuum of Saq conglomerate beds removed by erosion, but this interpretation is unlikely because conglomerate is uncharacteristic of the Saq at this level (more than $130 \mathrm{~m}$ above the base; Powers and others, 1966). A more reasonable alternative is that the quartz cobbles come from surficial materials deposited by the ancestral drainage systems of Wadi ar Rumah and Wadi al Jarir, because similar clasts are common in the terrace deposits adjacent to the modern courses of these channels.

Evidence derived from this quadrangle strongly suggests that the Saq began to accumulate in earliest Cambrian time, shortly. after intrusion and unroofing of the Qitan complex (Abanat suite of Cole, 1984c, pmen;about $585 \mathrm{Ma}$ to $570 \mathrm{Ma}$, Cole and Hedge, 1984, unpub. data). The altitude of the base of the Saq is about $1190 \mathrm{~m}$ at Jabal Timiyah, and ranges between $895 \mathrm{~m}$ (lat $26^{\circ} 30^{\prime} \mathrm{N}$.) and $760 \mathrm{~m}$ (lat $25^{\circ} 40^{\prime} \mathrm{N}$.) at the eastern outcrop limit of the Shield. These three points define a plane that intersects Jibal Qitan $110 \mathrm{~m}$ below its summit $(1172 \mathrm{~m})$.

Comparison of the projected Saq base with other Abanat-suite granites in the region also shows that their present-day summits are $300 \mathrm{~m}$ to $100 \mathrm{~m}$ higher, and they must have been emergent (by at least these amounts) during Saq deposition. The Abanat-suite granites are weathered and crumbly as a result of their exposure to arid climate during the late Cenozoic (Schmidt and others, 1982; Whitney, 989 smper "Cole, this report). Thus, it is unlikely that their topographic prominence at the end of the Proterozoic could have survived an extended period of erosion, and the granites must have been buried by early Saq deposits. 


\section{PROTEROZOIC INTRUSIVE ROCKS}

Intrusive rocks crop out over less than 10 percent of the Uqlat as Suqur quadrangle, and yet they represent most of the major Proterozoic magmatic events recognized in the region (fig. 2; Cole, inpros). They range in composition from diorite to leucocratic granite and range in age from the youngest to among the oldest rocks of the quadrangle. The intrusive rocks are distinguishable from each other on the basis of bulk composition and texture, degree of deformation and alteration, intrusive style, contact relationships with the major layered-rock units, and aeromagnetic signature. Most of the rocks can be confidently assigned to regional assemblages that are classified and defined in this report as the Suwaj suite and the Idah suite, or to the Abanat suite (Cole, 1984c, in prees).

Rocks of the Suwaj suite in this quadrangle consist of microdiorite and granodiorite granophyre that intrude the Dhiran meta-andesite and are unconformably overlain by the Murdama group. Stocks and batholithic plutons of the Idah suite consist chiefly of calc-alkaline granodiorite (minor diorite and syenogranite) that post-date the Murdama and Jurdhawiyah groups. The youngest, volumetrically significant intrusion consists of leucocratic granite defined. in this report as the Qitan complex, which represents the Abanat suite (Cole, 1984c, prat)in this quadrangle, and which was probably coeval with the Humaliyah formation. Radiometric age dating by Stuckless and others (1984) and unpublished data (1984) by the author and C. Hedge defines the absolute age of the Suwaj suite as $690 \mathrm{Ma}$ to at least $680 \mathrm{Ma}$, the Idah suite as $620 \mathrm{Ma}$ to $615 \mathrm{Ma}$, and the Abanat suite as $585 \mathrm{Ma}$ to $570 \mathrm{Ma}$ (Qitan complex: 580 Ma to $575 \mathrm{Ma})$.

Classification, definition, and correlation of intrusive rock units are much more subjective than for layered rock units, chiefly because of the spatial isolation of individual plutons. However, the defining characteristics of the suites are drawn from many independent lines of evidence that allow individual intrusive bodies to be classified with confidence, and that serve as the basis for correlation and extension to similar assemblages in the region. The relative ages of the compositional sub-units within these suites are probably variable from place to place and may not be constant across the regional outcrop extent of any suite. The age relationships between sub-units indicated by the order of description in the following sections is based on specific evidence in the Uqlat as Suqur quadrangle, and may not strictly apply elsewhere.

Dike rocks pose special classification problems because they crop out in limited areas, and their ages relative to widespread units are commonly more difficult to define. Dikes within and marginal to individual plutonic bodies are interpreted to be cogenetic with the intrusions and are described under the relevant section for the plutonic rock host. Dike swarms and small plugs that crop out wholly within layered rocks are classified in this report in four units, and are distinguished from each other by composition, degree of alteration and deformation, and relationship to the layered rock units.

The Deformed and altered dike rock unit is confined to the Murdama basins and was probably emplaced prior to Jurdhawiyah deposition. The Plagioclase porphyry unit consists of plugs and dikes of andesitic and dacitic composition, and are interpreted to be sub-volcanic conduit intrusions emplaced during Jurdhawiyah volcanic activity. Rocks of the Sodic microsyenite unit post-date the Jurdhawiyah, but appear to coincide with deformation in the Idayri basin and probably pre-date the Idah suite. A regional dike swarm defined as the Sanidine porphyry unit is correlated with the Abanat suite (Cole, 1984c, preston the basis of chemistry and cross-cutting relationships. 
Correspondences (fig. 2) between the intrusive suites of the Uqlat as Suqur quadrangle and the units used by previous authors in adjoining areas are very broad. However, most prior workers have also recognized three major intrusive episodes that correspond to the Suwaj, Idah, and Abanat suites, respectively: mafic and intermediate rocks that pre-date the Murdama; varied calc-alkaline rocks (chiefly granodiorite and monzogranite) that post-date both Murdama and Jurdhawiyah; and latest Proterozoic, leucocratic, alkali-rich granites that may have been contemporaneous with silicic volcanic activity.

Compositional terminology follows the recommendations of the International Union of Geological Sciences by its Subcommission on Systematics of Igneous Rocks (Streckeisen, 1976). Modal mineralogy (determined from potassium-stained slabs) was adjusted for many inequigranular rocks to correct for the composition of groundmass minerals and granophyric intergrowths. In leucocratic rocks, albite with average extinction angles more negative than $-10^{0}$ (sections normal to $\{0100\}$ and $\{0010\}$ ) was grouped with "alkali feldspar" (Streckeisen, 1976) for rock classification.

\section{SUWAJ SUITE}

The oldest intrusive rocks of the Uqlat as Suqur quadrangle consist of microdiorite and granodiorite granophyre that are classified as units of the Suwaj suite. Both units intrude the Dhiran meta-andesite southeast of Jibal al Khusayyayn as irregular bodies, and granodiorite granophyre intrudes the microdiorite. Leucocratic and granophyric rocks also crop out south and west of the town of Uqlat as Suqur in a fault-bounded block. In both areas, the local base of the Murdama group is located west of Suwaj outcrops, and abundant Suwaj clasts are contained in the Timiriyat conglomerate.

The principal unifying characteristic of rocks of the Suwaj suite is their stratigraphic position beneath the Murdama group. This suite is named for Jabal Suwaj west of Dukhnah (fig. 1), which is central to the main outcrop belt of the suite (Cole, in pnew; Bohannon, 1984). Within the region, the Suwaj contains quartz diorite, diorite, tonalite, low-potassium granodiorite (with and without granophyric textures), and minor metagabbro (Cole, in peses), and all rocks are distinctly altered and locally cataclastic. Cogenetic dikes are rare in the Suwaj in general, and are unknown in this quadrangle. The magnetic signature of the Suwaj terrane is distinctive (Kleinkopf and Cole, 1982; Cole, ix prese, this report) and characterized by short-wavelength, highamplitude anomalies that locally define a west-northwesterly alignment parallel to the regional trend of internal cataclastic foliation. The magnetic fabric is weak in this quadrangle, perhaps because all outcrops are within the Ata-Shara block (fig. 3) where rocks are pervasively deformed and magnetite has recrystallized.

\section{Microdiorite}

Microdiorite of the Suwaj suite (Sdr) crops out only in the Ata-Shara block, southeast of Jibal al Khusayyayn. It forms a small, irregular pluton (approximately 7 $\mathrm{km}^{2}$ ) and is exposed in low, rolling hills. Contacts with the Dhiran meta-andesite are sharp and generally smooth, although irregular dikes and meter-scale Dhiran xenoliths are locally present. Contact metamorphic effects have not been recognized, in large part because of later metamorphism in the Ata-Shara block. 
Typical microdiorite is melanocratic, equigranular, structureless, and avcrage grainsize is approximately 1.0 to $1.5 \mathrm{~mm}$. The rock consists of about 60 percent euhedral, weakly zoned plagioclase, 25 percent altered, euhedral hornblende, 10 percent combined quartz and microcline, and 5 percent magnetite-ilmenite, sphene, and apatite (fig. 4). Quartz forms poikilitic grains, as much as $5 \mathrm{~mm}$ in diameter, that surround plagioclase and hornblende. Microcline is rare and typically forms graphic intergrowths with quartz adjacent to plagioclase.

Primary textures are preserved in the microdiorite, but primary minerals have bcen extensively replaced. Plagioclase probably crystallized as andesinc-labradorite from the melt, but has lost calcium during alteration to calcite, epidote, and scricite, and only oligoclase relics remain. Most hornblende is totally replaced by pale, nearly isotropic chlorite and actinolite, but can be identified by fine-grained sphene that mimics the amphibole cleavage. Magnetite-ilmenite grains are typically surrounded by a thin mantle of sphene and leucoxene. Calcite is widespread in the rock, and is locally associated with coarse, subhedral epidote and irregular patches of barite. Sparse, radial-columnar aggregates of pale brown-to-blue pleochroic tourmaline are contained in some rock along the northern pluton border.

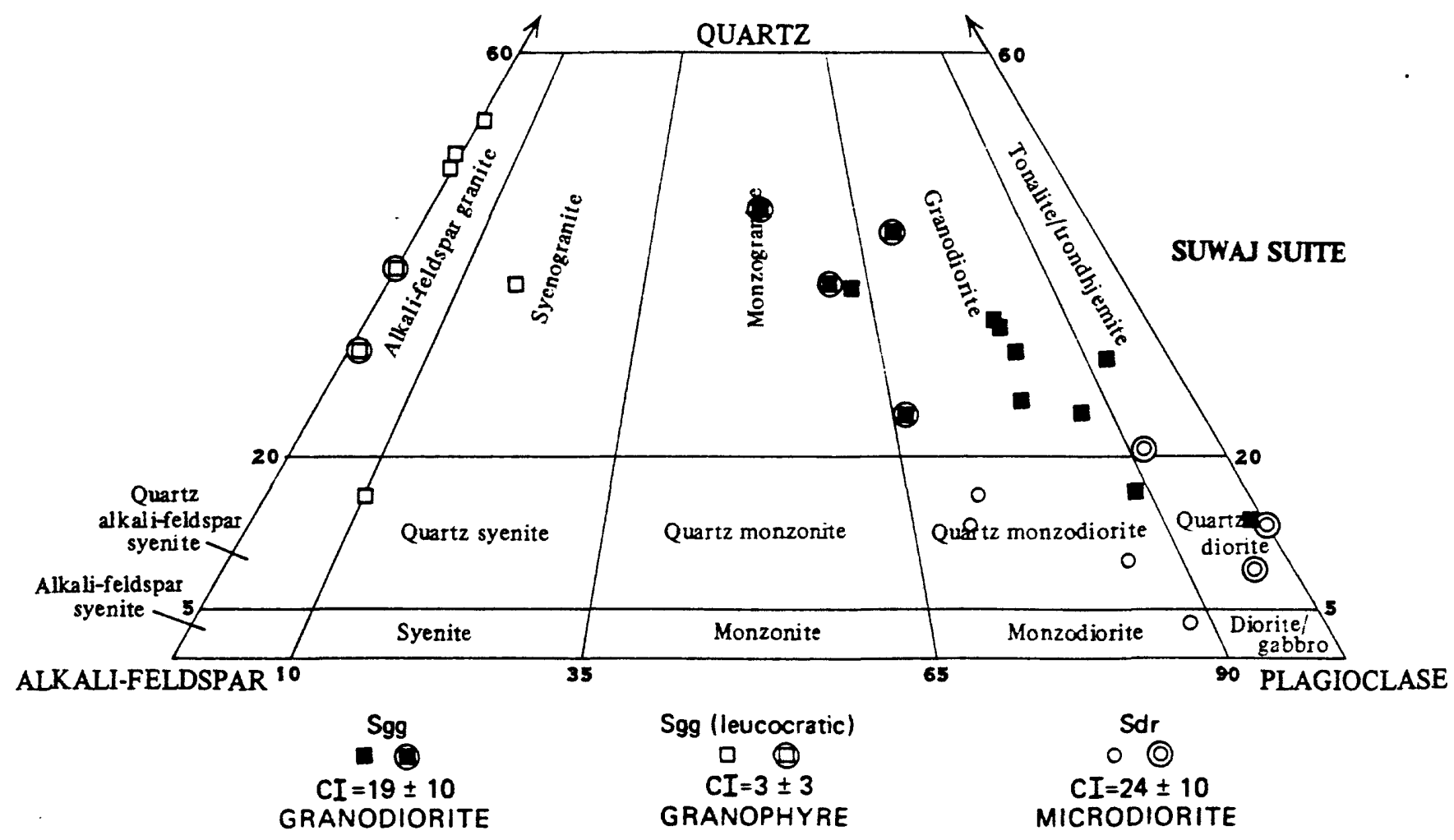

Figure 4.--Modal composition diagram for rocks of the Suwaj suite. Analyses for the Uqlat as Suqur quadrangle (circled) compared to regional data (Cole, 1982, 1984c) and regional average color index (CI; \pm one-sigma standard deviation). Rock-name fields and triangle poles defined by Streckeisen (1976). 


\section{Granodiorite granophyre}

Distinctive granodiorite and some leucogranite with a characteristic, coarsely granophyric texture are defined as the Granodiorite granophyre unit (Sgg) of the Suwaj suite. In this quadrangle, the unit is only exposed along the southern margin of the microdiorite body southeast of Jibal al Khusayyayn and in the fault-bounded block south and west of Uqlat as Suqur town. Outcrops are very poor but subcrop can be inferred from the characteristic pale orange-red colluvium; on this basis, granodiorite granophyre may be present in a third locality, west of Dihlat al Hasat and southeast of the base of the Murdama group (Timiriyat conglomerate), but was not confirmed. No magnetic anomalies are associated with this unit, probably because magnetite is generally absent.

Granodiorite granophyre intrudes the Dhiran and forms rare dikes in the Microdiorite unit. It is not in contact with the Murdama and Jurdhawiyah groups, but is clearly older because cobbles and boulders of this distinctive rock type are common in the conglomeratic units. The rock in these conglomerate clasts and in outcrop is identifiable by the coarse granophyric texture of the groundmass (visible with a hand lens), by its mineralogy, and by typical pale orange colors.

Granodiorite granophyre consists of 40 to 60 percent phenocrysts of sodic plagioclase ( 1 to $3 \mathrm{~mm}$ in diameter) and altered hornblende, and about 30 percent matrix composed of granophyric intergrowths of quartz and microcline (fig. 4). Modal composition ranges from quartz monzodiorite to monzogranite, but the variability is largely due to the proportions of phenocrystic plagioclase and hornblende.

A few samples of perthite granite (fig. 4), chiefly from the fault-bounded block west of Uqlat as Suqur, are distinctly leucocratic and typically contain embayed quartz phenocrysts, but are included in the unit because they also have a granophyric groundmass and pre-date the Murdama. Contacts could not be located between leucocratic and mafic varieties of the Granodiorite granophyre unit during reconnaissance, and it is not known if they are gradational or distinct. The two varieties are interpreted to be related because of texture and geologic setting, and also because their potassium:silica ratio is markedly lower than other intrusive rocks in the region (Cole, 1982, 1984b). The leucocratic granophyre is compositionally similar to the groundmass of the mafic granodiorite granophyre, and may have formed from it by extraction of phenocrysts (plagioclase, hornblende, and magnetite) during emplacement.

Granodiorite east of this quadrangle (Cole, 1984c) contains a cataclastic fluxion structure that is parallel and common to the other units of the Suwaj suite. Cataclasis is not pervasive but is localized along subparallel seams and braided zones that contain granulated feldspar and ribbon quartz. This fabric was not observed in the sparse outcrops in the Uqlat as Suqur quadrangle, but cataclastic granophyre cobbles are contained in the Murdama and Jurdhawiyah conglomerates here.

\section{DEFORMED AND ALTERED DIKE ROCKS}

Mafic and felsic dike rocks that are characterized by pervasive internal deformation and intense deuteric alteration form an identifiable assemblage in this quadrangle that only intrudes the Murdama group in the Mahalani basin (fig. 3). Mafic dikes form a south-southeast-trending swarm parallel to Shaib al Widayyat and Wadi al Mahalani, and similar dikes in the Ata-Shara block (fig. 3) trend west and southwest in the Jidhayib Marran area. Felsic dikes were generally emplaced in areas distinct from the mafic dikes and are more variably oriented although, in the Ata-Shara block west of Jidhayib Marran, northeasterly and northwesterly trends are dominant. 
Mafic dikes arc typically about $100 \mathrm{~cm}$ thick, traccable for hundreds of meters to scveral kilometcrs along strikc, planar and subvertical, and form slightly rcsistant ridges. Felsic dikes are generally thinner, less continuous, more irregular, and are less resistant than their host rocks.

The composition of the mafic rocks is cstimated to be andesitc or basalt. bascd on typical dark-brown and brown-grecn color, relict diabasic texturc, finc grain sizc, and sparsc mafic phenocrysts (probablc pyroxenc). The cxisting mincralogy is an alteration asscmblage containing relict calcic plagioclase laths and abundant chloritc, cpidotc, sphene, calcite, and rare baritc, actinolite, and (in sparse amygdulcs) quartz. The altercd matrix is locally replaced by additional quartz, and quartz-cpidotc veins arc locally common.

Felsic dike rocks consist of aphanitic aplite and the outcrop color is typically palc orange, palc pink, or tan. Phenocrysts of oligoclase and (rarely) quartz makc up about 10 percent of the rock, and the chief mafic minerals are sparse brown biotitc and hematite pseudomorphs after pyrite. The groundmass consists of intcrlocking, equant to irregular grains of oligoclase, quartz, and potassium feldspar; calcite, scricite, chlorite, and hematite comprise the alteration assemblage.

Within the Ata-Shara block (fig. 3), felsic dike rocks contain a pervasive planar fabric defined by sparse biotite and secondary sericite, and locally by elongate quartz and feldspar matrix grains. This fabric is not parallel to the dike margins, but rather is parallel to the chlorite-muscovite schistosity in the enclosing Murdama group. Barren quartz veins are abundant in the felsic dikes in this area and are 2 to $10 \mathrm{~cm}$ thick, typically oriented $N$. $5^{\circ}-40^{\circ}$ W. (regardless of dike trend), and terminate abruptly at the dike margins. These veins are only depicted schematically on the geologic map because they are so numerous that, in places, dike rock and vein quartz are about equally abundant.

\section{PLAGIOCLASE PORPHYRY}

The Plagioclase porphyry unit $(p p)$ is defined for andesitic and dacitic intrusive rocks that form short dikes and small plugs, primarily within the Jurdhawiyh group. Their outcrop in this quadrangle is chiefly within a $10-\mathrm{km}$ radius of the village of $\mathrm{Al}$ Maylih, but elongate plugs also intrude the Jurdhawiyah in the western Idayri basin (fig. 3) north and west of Jabal Akkash. Similar rocks are more abundant within the Jurdhawiyah in adjoining quadrangles (Cole, 1981; 1984c, inv pruss).

The tcrm "plagioclase porphyry" is used because it expresses the essential features of the unit, but it does not fully reflect the range of rock compositions. Rocks in these dikes and plugs typically contain at least 25 percent phenocrysts $(0.5$ to $3.0 \mathrm{~cm}$ in diameter) and plagioclase is most common. Howcver, phenocryst assemblages in individual intrusions include plagioclase-augite, plagioclase-augite-hornblende, plagioclase-augite-hypersthene; augitc-hypersthene, hornblende alonc, or (rarcly) plagioclase alone. These rocks are typical calc-alkaline andesitcs and dacites that contain 57 to 65 percent silica (Cole, 1982, 1984b). Dacite-rhyodacite (65 to 69 percent silica; Cole, 1982) makes up as much as 15 percent of the Plagioclase porphyry unit in adjoining areas, but only two of the sampled intrusions in this quadrangle are likely to be as siliccous. One crops out on the north slope of Jabal Idah and the other approximately mid-way between Al Maylih and the Al Habla East ancient workings, and both contain sparse biotite phenocrysts in addition to hornblende and sodic plagioclase. 
Rocks of the Plagioclase porphyry unit are brown or red brown in outcrop, more resistant than their host rocks, and form ridges and mounds that are mantled by spheroidally weathered blocks, 30 to $60 \mathrm{~cm}$ in diameter. This distinctive weathering characteristic has led to an unusual mapping aid: almost without exception, these spherical boulders are arranged as artifacts (stone rings, stone lines, and other designs) on the desert surface by prior inhabitants of the region.

These dikes and plugs generally intrude the layered rocks of the Jurdhawiyah group at the present level of exposure. Southeast of Jibal Budayn on the west bank of Wadi al Jarir, however, andesite porphyry of the Plagioclase porphyry unit appears to grade (or pass) into the base of a section of porphyritic andesite flow rock and flow breccia (Andesite unit, Jurdhawiyah group). The mineralogy and texture of these rocks are similar and they may be (respectively) intruded and extruded masses of the same magma batch. This conclusion can be generalized throughout the region, because the mineralogical and chemical traits of the Plagioclase porphyry unit are coincident with those in the volcanic units of the Jurdhawiyah, and fragments in the clastic units are also comparable (Cole, 1982; 1984b, c, in press).

Andesine is the typical phenocryst plagioclase and it is euhedral, locally encloses rounded masses of matrix (devitrified melt), and is commonly zoned in a complex patchy-to-oscillatory pattern. Augite is nearly colorless and forms euhedral, equant grains that are simply twinned on $\{100\}$. Hornblende is typically strongly colored and pleochroic from brown green to red brown, euhedral and elongate-prismatic, and rarely twinned; in the more mafic andesites, hornblende is surrounded by a thin reaction rim of granular pyroxene and magnetite. Biotite (where present) is euhedral and has an intense red-brown color. Magnetite and apatite are common euhedral accessory phases.

The groundmass in these rocks is very fine grained and typically structureless. Most of it consists of short, tabular laths of andesine-oligoclase, surrounded by granular magnetite, pyroxene, mesostasis, and variable amounts of interstitial quartz. Postemplacement alteration is moderate but variable, and its principal effects are the replacement of orthopyroxene by chlorite, serpentine, and granular magnetite, replacement of biotite by chlorite, sphene, and prehnite, and local replacement of groundmass by calcite, chlorite, and epidote. Plagioclase, augite, and hornblende are fresh or slightly altered.

\section{IDAH SUITE}

Granodiorite is the dominant lithology for rocks defined as the Idah suite, but compositional variants range from diorite to syenogranite. The four formation-rank sub-units of the Idah, defined in this report, are all exposed in the Uqlat as Suqur quadrangle and are subdivided principally on the basis of bulk composition and texture; they include the Granodiorite, Diorite, Granodiorite porphyry (with Granophyre member), and Granite units, and are recognizable throughout a large part of the northeastern Shield (Cole, fuises.; Johnson and Williams, 1984).

Rocks defined with the Idah suite share chemical and mineralogic traits that define a calc-alkaline series (Cole, 1982, 1984b), and they post-date the Murdama and Jurdhawiyah groups. Plutons of the suite are also distinguished by characteristic contact-metamorphic aureoles (hundreds of meters to as much as a kilometer wide), and the resulting recrystallization of magnetite in hornfels produces an annulus of shortwavelength, high-amplitude magnetic anomalies (Kleinkopf and Cole, 1982; Cole, im; this report). Cogenetic diabase and aplite-granite porphyry dikes are common in Idah suite intrusions, and discoid, cognate mafic inclusions (2 to $15 \mathrm{~cm}$ in diameter) are typical in many of the units. Most Idah suite plutons are smoothly elliptical or circular 
in plan, country-rock contacts are sharp and subvertical, and xenoliths are rare (Cole, $1981,1984 \mathrm{c}$, press,this report). Although the rocks of this suite are typically fresh, dense, and well indurated, outcrop is characteristically poor, and plutons coincide with shallow, internally drained depressions. Suites do not have type localities (DMMR, 1984), but this suite is named for Jabal Idah in the southeastern corner of this quadrangle, where intrusive contacts with the Murdama and Jurdhawiyah groups are well exposed, as are characteristic features of intrusive style, outcrop, and magnetic signature.

The Granodiorite unit of the Idah suite is poorly exposed along the southern border of the Uqlat as Suqur quadrangle, where it forms the northern margin of a heterogeneous batholithic mass that extends southward to the Halaban-Zarghat fault (fig. 1; Young, 1982; Cole, im prew). The Diorite and Granodiorite porphyry units are exposed in stocks and elliptical plutons south of the Lughfiyah-Shuhban fault system and north of the Ata fault in the Mahalani and Maraghan basins (fig. 3). The Granite unit is represented in this quadrangle by the elliptical pluton at Al Habla.

Granodiorite is interpreted to be older than the three other units because it is intruded by granodiorite porphyry and by granite in the Al Habla-Al Madraba area, and may be partly equivalent to the (pre-Jurdhawiyah) Khishaybi suite east of this quadrangle (Cole, exprew). The three younger units were emplaced in individual (pre-Jurdhawiyah) plutons and relative ages cannot be determined by cross-cutting contacts; they are described in order from mafic to felsic, which may reflect the chemical evolution of the suite (Cole, 1984a).

\section{Granodiorite}

Intrusive rocks exposed across the southern boundary of the quadrangle consist of leucocratic, equigranular biotite-hornblende granodiorite (Igd) that extends southward for tens of kilometers within a heterogeneous intrusive terrane (Young, 1982). Outcrop is characteristically poor, but the intricate magnetic signature of the area (Kleinkopf and Cole, 1982), petrographic inhomogeneity (Young, 1982; Arnold, 1984), and the distribution and orientation of various dike swarms suggest the terrane is a composite of several intrusions (Cole, the report). Granodiorite in the Uqlat as Suqur quadrangle, which forms the northern part of this terrane, is more homogeneous in all respects and appears to be a single intrusion.

The intrusive contact with rocks of the Jurdhawiyah and Murdama groups is sharp and steep (based on magnetic gradients), and traces out lobate embayments in the layered rocks. This contact is rarely exposed, however, and outcrop is generally limited to flat slabs in the bottoms of small drainage channels, zones marginal to resistant dikes, and the bouldery ridge south of Shaib Darah and the sub-parallel fault.

Typical granodiorite is pale pink, pale orange, or tan, medium grained, structureless, and hypidiomorphic-equigranular to weakly seriate-porphyritic. The average modal composition is 48 percent subhedral plagioclase, 22 percent quartz, 17 percent orthoclase, and 13 percent mafic minerals (fig. 5). Hornblende and biotite are present in subequal amounts, and magnetite, sphene, and apatite are typical accessory minerals. Most plagioclase is andesine-oligoclase, weakly to moderately zoned, and contains small inclusions of hornblende, biotite, magnetite, and (rarely) augite. Orthoclase is weakly perthitic, untwinned, and contains sparse myrmekite lobes adjacent to plagioclase. Hornblende and biotite are typically clustered in aggregates that are also rich in accessory minerals. 
In general, quartz and feldspars in granodiorite are not altered, but hornblende is locally replaced by fine-grained biotite, and primary biotite is replaced by chlorite and prehnite along cleavage planes. Near fault zones, however, orange-red granodiorite is slightly granulated and the feldspars are partially replaced by sericite, hornblende and biotite are wholly replaced by chlorite and secondary biotite, and magnetite is converted to hematite.

\section{Diorite}

The large elliptical stock south of Jabal Akkash ( $3 \mathrm{~km}$ wide by $7 \mathrm{~km}$ long) and five small plugs (less than $2 \mathrm{~km}^{2}$ ) in the Uqlat as Suqur quadrangle contain biotitehornblende diorite and are defined as the Diorite unit (Idr) of the Idah suite. Three of the small plugs intrude Murdama sandstone approximately $4 \mathrm{~km}$ southeast of Jabal Akkash, one is central to the ancient workings at An Najadi on the northern quadrangle border, and the fifth crops out $3 \mathrm{~km}$ northeast of At Tarfawi in the Mahalani basin (fig. 3; pl. 1).

Contacts with country rock are generally not exposed, except at An Najadi where they are sharp and steep. Contact metamorphism adjacent to the Diorite unit is more widespread than around other units of the Idah, as indicated by the high arcuate ridge surrounding the pluton at Jabal Akkash and by several hundred meters of hornfels around even the smallest plugs. The age of the Diorite unit relative to the other units of the Idah suite is indeterminate because diorite was emplaced in separate areas. However, a small plug and a few short dikes of leucocratic, muscovite-bearing granite intrude the diorite pluton at Jabal Akkash, and may correlate with the Granite unit.

Diorite is rarely exposed in outcrop, but forms dark gray blocks and boulders that locally project through gray colluvial cover. The rock is medium grained, hypidiomorphic-equigranular, and contains few of the discoid mafic inclusions typical of granodioritic units of the suite. Average diorite contains about 65 percent euhedral to subhedral plagioclase, 30 percent mafic minerals (hornblende, biotite, and augite), and 5 to 10 percent quartz and orthoclase (fig. 5). Hornblende is three times more abundant than biotite in most samples, and augite is only present as irregular grains in the cores of hornblende phenocrysts.

Most plagioclase is andesine and is characterized by delicate oscillatory zoning, and by thin rims of intermediate oligoclase. Euhedral hornblende and subhedral biotite typically form clusters that also contain most of the accessory magnetite, apatite, and sphene. Interstitial quartz is equigranular, but orthoclase forms larger, irregular grains that poikilitically enclose all other minerals.

Quartz, orthoclase, magnetite, and augite are typically fresh in the diorite, but plagioclase is locally altered to fine-grained sericite and a little epidote. Hornblende is partially replaced by pale actinolitic amphibole and chlorite, and biotite is more widely converted to chlorite and granular sphene.

The small diorite plug $3 \mathrm{~km}$ northeast of At Tarfawi is slightly different from the other bodies of the unit. The rock is fine grained, has a diabasic texture, and is richer in augite and hornblende. 

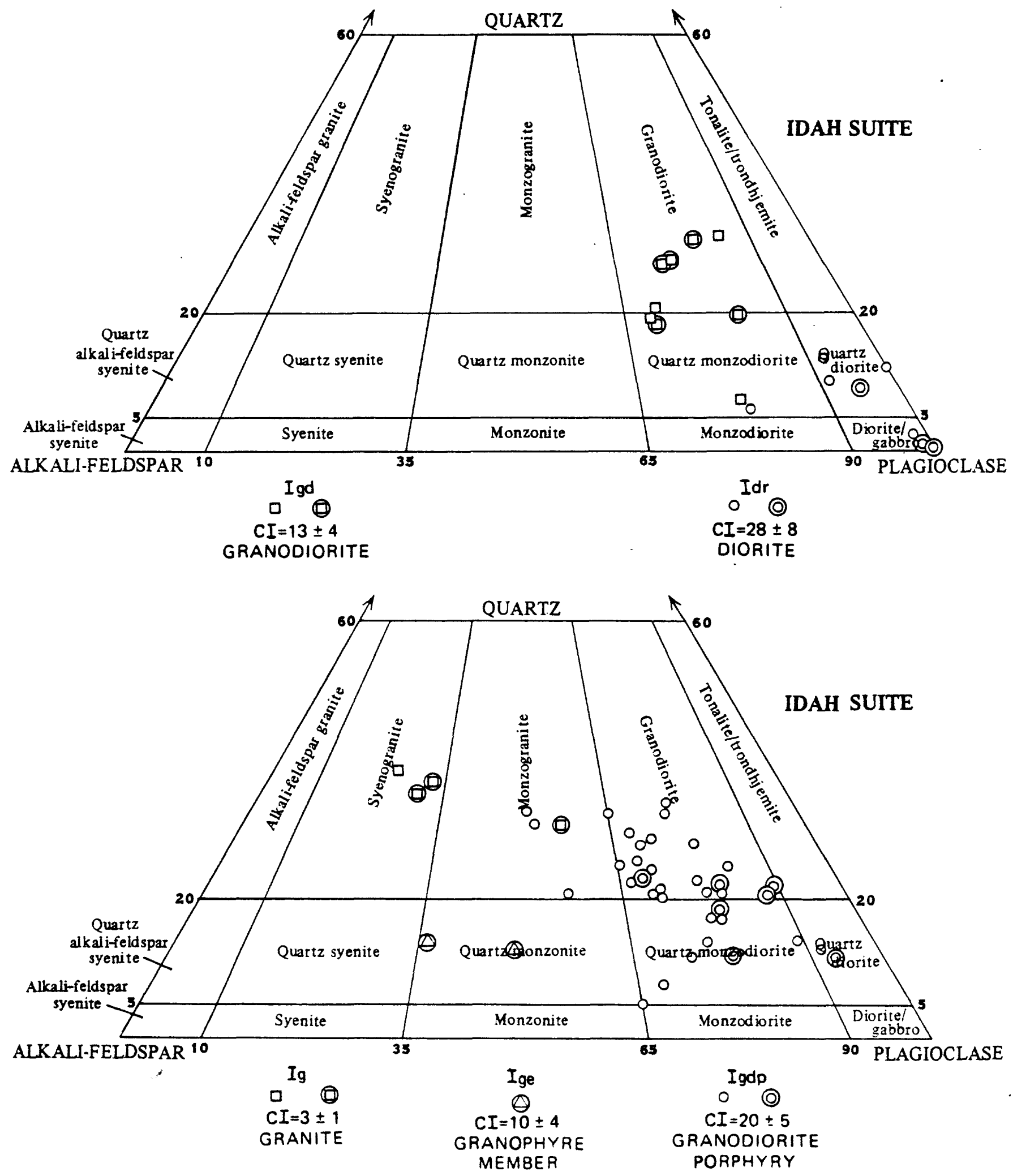

Figure 5.--Modal composition diagram for rocks of the Idah suite. Analyses for the Uqlat as Suqur quadrangle (circled) compared to regional data (Cole, 1982, 1984c) and regional average color index (CI; \pm one-sigma standard deviation). Rock-name fields and triangle poles defined by Streckeisen (1976). 


\section{Granodiorite porphyry}

The Granodiorite porphyry unit (Igdp) is the most widespread and voluminous of the Idah suite in the northeastern Shield (Cole, in piew) and crops out in the northern and southern parts of the Uqlat as Suqur quadrangle. Plutons are typically circular to smoothly elliptical and define three modal size classes. Granodiorite porphyry in the vicinity of Jabal Idah defines the northern margin of an elliptical pluton that is about $600 \mathrm{~km}^{2}$ in area. Intermediate-sized plutons $\left(15\right.$ to $\left.20 \mathrm{~km}^{2}\right)$ are located at Al Madraba on the southern quadrangle border, and at Al Khullah and Darat Ata in the Maraghan basin (fig. 3). Small plugs (1 to $2 \mathrm{~km}^{2}$ ) are exposed $6 \mathrm{~km}$ north of At Tarfawi east of Wadi al Mahalani, but are more widespread to the east and north (Cole, 1984c; Johnson and Williams, 1984).

Granodiorite porphyry at Al Madraba intrudes the older Granodiorite unit, but its age relative to the Diorite and Granite units is unknown. Contacts between granodiorite porphyry and layered rocks of the Murdama and Jurdhawiyah groups are typically sharp and smooth and wall-rock inclusions are rare. Contact-metamorphic aureoles are typical, and the lateral extent of hornfels recrystallization is proportional to the areal size of the intrusion.

Contact geometry is particularly well exposed at the north end of the largest pluton in the vicinity of Jabal Idah because part of the roof is preserved at the foot of the mountain beneath Jurdhawiyah rocks. The roof is sub-horizontal and the uppermost parts of the intrusion are locally marked by red-orange lenses of the Granophyre member (described below). In adjoining areas to the south, this flat roof contact is exposed at the foot of Jabal Khathariq and at the southern pluton margin near Jibal al Muqawqi (Cole, 1981; Young, 1982), approximately 10 to $30 \mathrm{~m}$ above the present ground surface at a fairly constant altitude of 810 to $820 \mathrm{~m}$. A gravity profile across the south-central part of this intrusion was interpreted to indicate a flat floor at a depth of 4 to $7 \mathrm{~km}$ (Kleinkopf and Cole, 1982). Lateral contacts are known or inferred to be sub-vertical on the basis of local exposure (Cole, 1981) and sharp magnetic gradients (Kleinkopf and Cole, 1982; Cole, this report). Thus, the intrusive body has a tabular shape $(33 \mathrm{~km}$ by $20 \mathrm{~km}$ by $4-7 \mathrm{~km})$, and a similar shape can be inferred from other large and intermediate-sized granodiorite porphyry plutons on the basis of magnetic anomaly character (Kleinkopf and Cole, 1982; Cole, this report).

Granodiorite porphyry is gray to brown-gray in outcrop and typically contains a few percent cognate, discoid inclusions $(2$ to $15 \mathrm{~cm}$ in diameter) that are rich in hornblende, biotite, augite, and accessory minerals. The characteristic trait of the unit is about 20 percent phenocrysts of plagioclase ( 8 to $12 \mathrm{~mm}$ in diameter) that are uniformly distributed in the rock. These phenocrysts generally have a blue-gray core zone (due to abundant inclusions of hornblende, magnetite, biotite, and augite) and a thin white rim. Most of the rock is medium grained, and the texture ranges from porphyritic to seriate-porphyritic to subequigranular, depending on the local proportion and size of plagioclase phenocrysts.

Regardless of location or the size of the intrusive body, granodiorite porphyry typically contains 35 to 45 percent andesine-oligoclase (phenocrysts plus groundmass), 12 to 20 percent quartz, 7 to 20 percent orthoclase, and 15 to 20 percent (rarely, as much as 30 percent) mafic minerals (fig. 5 ; most of the scatter in this diagram is due to inherent inaccuracy in modal analysis of porphyritic rocks). Hornblende and biotite are present in subequal amounts, and augite, magnetite, sphene, apatite, and zircon are the typical minor and accessory minerals. 
Most plagioclase phenocrysts have mid-range andesine cores, and the composition grades through minor oscillations to mid-range oligoclase rims. Groundmass plagioclase is calcic oligoclase, subhedral, and weakly zoned. Hornblende is euhedral to subhedral, pleochroic, olive green to brown green, and locally contains irregular cores of augite. Biotite is typically dark brown and contains abundant small zircon grains surrounded by pleochroic haloes. Quartz is equant and interstitial, whereas orthoclase is irregular and poikilitic. Myrmekite is common between plagioclase and orthoclase.

Granodiorite porphyry is largely unaltered, but samples collected near contacts are partially replaced by sericite (plagioclase), actinolite (hornblende), and chlorite plus sphene (biotite). The small plug of biotite granodiorite $5 \mathrm{~km}$ north of At Tarfawi is more intensely altered to sericite and chlorite, and is more leucocratic than other rocks of this unit (plagioclase is calcic oligoclase, color index is 7 , and hornblende is absent).

Granophyre member.--Discontinuous lenses, sheets, and minor dikes of brick red to red orange, weakly porphyritic granophyre are exposed at the roof of the pluton at Jabal Idah and are defined as the Granophyre member (Ige) of the Granodiorite porphyry unit. The sheets and lenses are 5 to $20 \mathrm{~m}$ thick, and short dikes locally project from them into the overlying layered rocks of the Jurdhawiyah group (Cole, 1984c).

Orange phenocrysts of zoned andesine-oligoclase ( 3 to $9 \mathrm{~mm}$ in diameter) are present in variable amounts (but less than about 10 percent) and are texturally similar to phenocrysts in the subjacent granodiorite porphyry. Biotite and minor hornblende are subhedral to irregular and comprise about 15 percent of the rock. These minerals are contained in a fine-grained groundmass that consists of equant, unzoned oligoclase and 10-micron-scale graphic intergrowths of quartz and orthoclase. The modal composition of the granophyre is quartz monzonite (fig. 5) and reflects the small amount of quartz that is only present in the granophyric groundmass. The granophyre is slightly enriched in molybdenum, copper, and beryllium relative to granodiorite porphyry (Cole, 1982, 1984b).

Granular hematite is dispersed in the feldspar and accounts for the bright red color of the rock. Plagioclase is moderately replaced by sericite, most of the biotite is altered to chlorite, and magnetite is replaced by hematite.

\section{Granite}

Leucocratic syenogranite porphyry in an elliptical pluton at Al Habla is defined as the Granite unit (Ig) of the Idah suite. This body is about $10 \mathrm{~km}$ long and $4.5 \mathrm{~km}$ wide and intrudes layered rocks of the Murdama and Jurdhawiyah groups along its south, east, and north margins, and intrudes the Granodiorite unit along its western contact. Its age relative to the Diorite and Granodiorite porphyry units is not known, although the granite at $\mathrm{Al} \mathrm{Habla} \mathrm{is} \mathrm{interpreted} \mathrm{to} \mathrm{be} \mathrm{younger} \mathrm{than} \mathrm{granodiorite} \mathrm{porphyry} \mathrm{at} \mathrm{Al}$ Madraba on petrologic grounds (Cole, 1984a). A small leucogranite plug and short dikes (described at the end of this section) intrude the Diorite unit at Jabal Akkash, but they are somewhat different and their inclusion with the Granite unit is uncertain.

Granite of the Idah suite, as exemplified by the pluton at Al Habla, is mineralogically similar to some granite in the younger Abanat suite (Cole, 1984c, is plums) because it is leucocratic and porphyritic. However, it differs in that it crops out poorly, it contains oligoclase (rather than albite), it lacks fluorite, and it contains more copper, barium, strontium, and calcium and less fluorine, lithium, tin, tungsten, and beryllium than the granites of the Abanat suite (Cole, 1982, 1984a, b, in press). 
Contacts between the granite at $\mathrm{Al}$ Habla and surrounding rock are not well exposed, but appear to be sharp and smooth, and the magnetic gradient at the margin suggests a steep contact (Cole, this report). Contact metamorphism (biotite-cordicritemagnetite hornfels) is detectable within about $100 \mathrm{~m}$ of the contact, although is more widespread to the south where staurolite is locally present, probably due to compound thermal effects from both the Al Habla and Al Madraba intrusions.

The Al Habla pluton is weakly zoned, and the border phase is about $1000 \mathrm{~m}$ wide along the eastern and southeastern margins, several hundred meters wide on the southwestern margin, and forms a protruding lobe at the western end of the body. The core phase forms a subcircular mass of tan syenogranite with about 70 percent phenocrysts (quartz, microcline, and oligoclase) in a fine-grained matrix, whereas the border phase is red orange, contains fewer phenocrysts in finer-grained matrix, and locally grades into pegmatite cavities and aplitic zones.

Phenocrysts and groundmass in bo:h phases consist of subequal amounts (fig. 5) of quartz, weakly zoned oligoclase, and microcline (locally orthoclase). Red-brown biotite is the principal mafic mineral and is locally accompanied by coarse, irregular plates of pale-brown, weakly pleochroic zinnwaldite that also appears to be a primary phase; together, these micas comprise only about 7 percent of the rock. Accessory minerals include magnetite, zircon, and apatite.

The core phase of the granite at Al Habla is very slightly-altered (sericite in oligoclase), but the border phase is oxidized and its red color is due to disseminated granules of secondary hematite. Feldspars in the border phase are stained by hematite and partially replaced by sericite, calcite, and clay(?) minerals. Hematite also replaces coarse cubes and pyritohedrons ( 1 to $2 \mathrm{~cm}$ in diameter) of pyrite; these pseudomorphs have only been found in weathered grus, and it is not known whether they crystallized with the granite, with pegmatite-aplite, or whether they formed during alteration.

The leucogranite plug within the Diorite unit south of Jabal Akkash is medium grained, pale pink, and consists of 5 percent quartz phenocrysts, 18 percent subhedral oligoclase phenocrysts, and about 5 percent coarsely crystalline muscovite enclosed in a coarse, graphic intergrowth of quartz and orthoclase.

\section{Dikes}

Diabase, granite porphyry, and aplite dikes are common in many intrusions correlated with the Idah suite, but most dikes in this quadrangle are associated with the Granodiorite unit along the southern border and with the larger bodies of the Granodiorite porphyry unit. Dike sets of various compositions and trends define age relationships within individual plutons, but these relationships are not regionally consistent and dikes are all interpreted to be essentially coeval.

Mafic dikes are more resistant than felsic dikes, both are typically more resistant than the host plutonic rock, and they form low outcrop ridges. Dike contacts are generally sharp and subvertical, although a few felsic dikes near Shaib Mutribah are flat-lying, as indicated by their sinuous outcrop pattern. These dikes rarely extend beyond the borders of the intrusion into country rock. Throughout the quadrangle, two dominant trends are evident in both malic and felsic dikes: west-northwest and north-northeast. 
Mafic dike rocks are typically dark, brown green, fine grained, and sparsely porphyritic, and most have a diabasic texture. Their composition is estimated to be andesite on the basis of the dominant minerals andesine, hornblende, and magnetite. These rocks are variably altered to a sericite-chlorite-epidote-calcite assemblage, although the alteration is generally slight.

Aplite and granite porphyry (not distinguished on geologic map) are similar in composition and differ chiefly by the presence or absence of feldspar phenocrysts. They are typically red, red orange, pink, or (rarely) gray in outcrop, fresh, and have a fine-grained, equigranular texture. Quartz and orthoclase are most common and are locally accompanied by sodic plagioclase; biotite, the characteristic dark mineral, rarely exceeds 5 percent of the rock.

\section{SODIC MICROSYENITE}

Small, irregular plugs and short dikes that intrude the Jurdhawiyah group and that are composed of a peculiar, oligoclase-rich rock are defined as the Sodic microsyenite unit (msy). Eight irregular bodies (more than $1 \mathrm{~km}^{2}$ ) are present in the Idayri basin between Jabal ash Shuhayba and the Shara fault, and one lobate plug intrudes the southeastern margin of the Shuqrah basin (fig. 3). The maximum age of these rocks is defined by their intrusion into the youngest Jurdhawiyah deposits (Shara conglomerate) and by intrusion into the eastern part of the Shara fault, but the minimum age is conjectural. The Sodic microsyenite unit is mineralogically and chemically unlike any other intrusive rocks in the region (Cole, 1982, 1984b), and so it is not correlated with either the Idah or Abanat (Cole, 1984c) suites. The unit is interpreted in this report to have formed during the major phase of movement on the Lughfiyah-Shuhban, Shara, and Ata faults because of its spatial association with these structures; thus, it is approximately contemporaneous with the Idah suite.

The small plugs and dikes of the Sodic microsyenite unit have sharp but extremely irregular contacts, and wall-rock inclusions are rare. Contact metamorphic effects are typically absent (except for local growth of epidote, andradite garnet, and coarse calcite in the Shara conglomerate), and magnetite does not appear to have formed, because sodic microsyenite intrusions have no associated magnetic anomalies.

Typical outcrops are blocky and closely fractured but more resistant than country rock, and are characterized by mottled red, red-orange, and tan colors. The rock is generally structureless but locally contains faint, millimeter-scale banding that outlines irregular, ropy fold forms. Sodic microsyenite is extremely fine grained and contains sparse phenocrysts of sodic plagioclase (less than $2 \mathrm{~mm}$ in diameter).

Throughout its area of outcrop, the unit has an unusual composition consisting of about 80 percent trachytically aligned, euhedral laths of oligoclase, 15 percent groundmass quartz, and less than a few percent combined magnetite, apatite, sphene, and (rare) biotite. All samples were stained to detect potassium feldspar, and the very weak reaction of the groundmass indicates that it forms no more than 5 percent of the rock. In the Streckeisen (1976) classification, this rock would be named "quartz anorthositen, although anorthositic rocks typically contain a more calcic plagioclase with pyroxene/amphibole; the name "trondhjemite" could also be applied, but these rocks contain less quartz and mafic minerals than characteristic of trondhjemite. The unit is named "sodic microsyenite" to emphasize its high feldspar and low quartz content (syenite), its feldspar composition (sodic), and its fine grainsize (micro). 
Oligoclase is altered to varying degrees to sericite and is locally replaced by calcite. Margins of euhedral magnetite grains are typically replaced by hematite. Irregular patches in the rock contain small, terminated quartz crystals and coarse calcite, and these patches may have been primary voids.

\section{QITAN COMPLEX}

The rocks of the youngest major intrusive event in the northeastern Shield are defined as the Abanat suite (Cole, 1984c, pris and are chiefly represented in the Uqlat as Suqur quadrangle by leucocratic, biotite-muscovite-bearing albite-orthoclase granite defined as the Qitan complex (Cole, this report). The composite pluton at Jibal Qitan forms a northeast-trending ellipse whose dimensions are $14 \mathrm{~km}$ by $11 \mathrm{~km}$. Only the southern half of the intrusion is contained in this quadrangle, but the definition and description of the complex are based on all available information (Williams, 1983; Cole, this report, unpublished mapping, 1981).

Stuckless and others (1984) determined three consistent ages for the rocks of the Qitan complex. Six whole-rock samples define a rubidium-strontium isochron age of $579 \pm 4 \mathrm{Ma}$ that is considered the most definitive. Muscovite and biotite separated from the sample collected one $\mathrm{km}$ southwest of $\mathrm{A}^{\prime}$ (pl. 1) were analyzed by potassium-argon techniques and define ages of $577 \pm 22 \mathrm{Ma}$ and $552 \pm 24 \mathrm{Ma}$, respectively. The biotite age probably reflects partial loss of argon, but its analytical uncertainty overlaps with that of the more precise rubidium-strontium isochron age.

The Qitan complex consists of a subcircular central intrusion ( $8 \mathrm{~km}$ in diameter) of the Granite porphyry member, a partial outer ring of the Biotite granite member, and dikes (internal pegmatite-aplite sheets and external granite porphyry). The contacts between the Biotite granite member and Murdama wall rock and between the two granite members are sharp, smooth, and typically inclined at more than $80^{\circ}$ away from the intrusion center. Conversely, the internal pegmatite-aplite sheets generally dip $15^{\circ}$ to $30^{\circ}$ toward the center. The Granite porphyry member appears to be slightly younger than the Biotite granite member on the basis of sparse, irregular protrusions, but the contact is locally gradational through an aplitic phase.

Along the northwestern margin of Jibal Qitan in the Samirah quadrangle to the north, the highest peak of the area $(1172 \mathrm{~m})$ is capped by $30 \mathrm{~m}$ of horizontally layered, aplite-cemented breccia that is interpreted to have formed by explosive exsolution of a vapor phase from the magma beneath the original roof of the intrusion (Cole, this report). The Biotite granite member in this area contains numerous pegmatite sheets and miarolitic cavities that are most abundant beneath the breccia cap.

The highest peaks of the outer ring of Biotite granite member are typically more than $1100 \mathrm{~m}$ above sea level, whereas outcrops of the Granite porphyry member are all less than $1100 \mathrm{~m}$ and most are less than $1030 \mathrm{~m}$. Near the north end of cross-section A-A' (pl. 1), Biotite granite rests on Granite porphyry above a flat, sub-horizontal contact at about $980 \mathrm{~m}$. These facts suggest that Biotite granite may have formed a thin carapace across the entire roof of the pluton, although it is not known whether the contact at $980 \mathrm{~m}$ represents an irregularity in the top of the Granite porphyry member or whether it marks the base of a block of Biotite granite member that was displaced (downward) during intrusion of the Granite porphyry member.

The elliptical outline of the Jibal Qitan mountains is contained within a larger, circular feature (14 $\mathrm{km}$ in diameter) that is defined by the annulus of high-frequency, marginal magnetic anomalies (ARGAS, 1967; Cole, this report). The magnetic boundary coincides with the intrusive contact (and the topographic margin of Jibal Qitan) 
around most of the southeastern, eastern, and northern margins of the complex, but no granite is exposed along the western magnetic boundary in a crescent-shaped area that extends through almost $200^{\circ}$ of arc and varies from a few hundred meters to as much as $5 \mathrm{~km}$ wide.

The center of the Qitan intrusive complex (defined by the sub-circular mass of the Granite porphyry member and the geometric center of inward-dipping pegmatite-aplite sheets) is nearly cocentric with the center of the magnetic annulus, but the Biotite granite member is absent along the western and northwestern margins. It is unlikely that the Biotite granite member was emplaced in the crescent-shaped area, altered, and later eroded, because no indication of such alteration is detectable in the Biotite granite member or in the Murdama wall rocks adjacent to the crescent. The interpretation favored in this report is that the Qitan complex was emplaced near the center of an unexposed, circular intrusion of the Idah suite (similar to the deeply eroded plutons at Darat Ata and Al Khullah; pl. 1). If true, this body would be the largest and northwesternmost of Idah-suite plutons that form an arcuate array near the western margin of the Maraghan basin (fig. 3).

\section{Biotite granite member}

The outer rim of the Qitan complex, approximately 1.5 to $3 \mathrm{~km}$ wide, consists of coarse-grained, equigranular biotite orthoclase granite and is defined as the Biotite granite member (qg). It forms smooth, exfoliated knobs that crop out 250 to $300 \mathrm{~m}$ above the surrounding plains and is generally pale pink or tan, although some areas near the margins of the complex are red or red orange. Average Biotite granite is about four times more radioactive than country rock and about 30 percent higher than the Granite porphyry member (outcrop measurements, total-count scintillometer; Cole, 1984b).

Typical Biotite granite contains 55 to 70 percent tabular, anhedral orthoclase (5 to $8 \mathrm{~mm}$ in diameter), 25 to 35 percent subhedral quartz ( 3.5 to $5 \mathrm{~mm}$ in diameter), and as much as 10 percent lath-shaped sodic albite (fig. 6). Minor and accessory minerals, which rarely comprise more than 5 percent of the rock, include ragged grains of dark green-brown to brown pleochroic biotite, equant grains of primary fluorite, zoned (partly metamict) prisms and minute needles of zircon, and minor amounts of magnetite.

Orthoclase is intensely perthitic and a great deal of the exsolved albite forms irregular veins, crystallographically aligned patches, and granular aggregates between orthoclase grains. Primary magmatic albite forms independent laths and appears to have crystallized late because it is interstitial to quartz and orthoclase. Subhedral quartz grains are typically aggregated into clusters ( 5 to $10 \mathrm{~mm}$ in diameter) that are gray and waxy in hand specimen.

Biotite and magnetite are evenly dispersed in the rock but commonly occur together with fluorite and zircon. Fluorite is also present in the interstices between quartz and orthoclase grains. The cores of some albite grains contain orange-yellow phyllosilicate minerals (nearly isotropic) that may be pinite replacements of cordierite.

The Biotite granite member is only slightly altered, chiefly by sericite in feldspar. and by local hematite replacement of magnetite and biotite. Sub-micron granules of hematite are also widespread along exsolution boundaries in orthoclase and produce the pale pink color that is typical of the unit. 


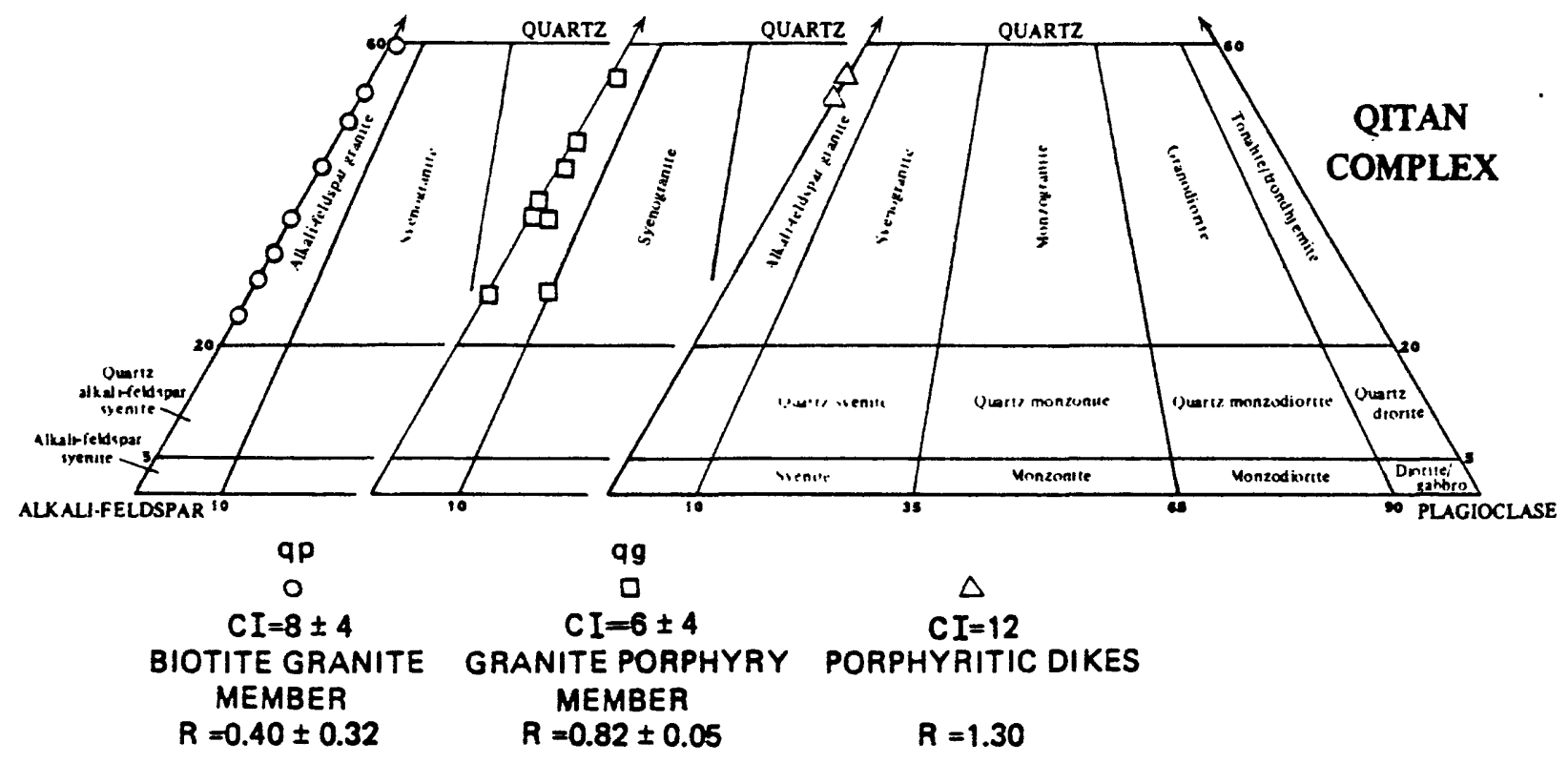

Figure 6.--Modal composition diagram for rocks of the Qitan complex. Analyses, average color index $(C I)$, albite-potassium feldspar ratio $(R)$, and variation ( \pm one-sigma standard deviation) are for samples from the entire complex. Rock-name fields and triangle poles defined by Streckeisen (1976).

\section{Granite porphyry member}

The central core intrusion of the Qitan complex consists of medium-grained, gray to white, porphyritic, muscovite-bearing biotite albite-orthoclase granite that is defined as the Granite porphyry member (qp). The rock typically contains 10 to 30 percent phenocrysts of quartz and orthoclase ( 3 to $8 \mathrm{~mm}$ in diameter) and widely dispersed 2- to $3-\mathrm{cm}$ clusters of biotite, fluorite, and magnetite. Rocks of the Granite porphyry member crop out in exfoliated knobs that are typically 50 to $100 \mathrm{~m}$ lower than surrounding outcrops of the Biotite granite member.

The essential mineralogy of the Granite porphyry is very similar to the Biotite granite, but quartz ( 25 to 35 percent), orthoclase ( 35 to 45 percent), and interstitial laths of albite (25 to 30 percent) are present in roughly equal amounts (fig. 6). Quartz and the feldspars are generally subhedral and are evenly distributed throughout the rock; myrmekitic intergrowths of quartz and albite are common. Mafic minerals comprise 2 to 7 percent of the rock, and red-brown to brown pleochroic biotite is dominant. Many of these crystals have a marginal fringe of gray-green biotite that is intricately intergrown with droplets of quartz. Fluorite, magnetite, zoned prisms and acicular grains of zircon, and rare cordicrite(?) are similar in amount and habit to their counterparts in the Biotite granite member.

Muscovite is unique to the Granite porphyry member and forms coarse, poikilitic plates ( 3 to $6 \mathrm{~mm}$ in diameter) that are distinctive in hand specimen, although 
muscovite generally makes up no more than one percent of the rock. Muscovite appears to replace orthoclase as irregular, optically continuous grains and as thin platelets parallel to the feldspar basal cleavage.

\section{Dikes}

Two types of dikes are interpreted to be genetically related to the Qitan complex, and they include pegmatite-aplite sheets within the granite members and porphyritic microgranite dikes that intrude Murdama sandstone at the southwest margin of the complex.

Aplite and pegmatite sheets are intergradational and discontinuous along strike, and they dip gently toward the center of the complex. Aplite is texturally and mineralogically similar to the groundmass of the Granite porphyry member and consists of sub-equal amounts of quartz, orthoclase, and albite with traces of biotite and magnetite. Minor variations in grainsize locally produce faint layering in the aplite that is typically parallel to sheet margins, although cross-stratification is also present.

Pegmatite sheets and irregular pods chiefly contain very coarse crystals of quartz and orthoclase ( 2 to as much as $10 \mathrm{~cm}$ in maximum dimension) and local coarse books of muscovite and biotite. Many of these pegmatites contain central voids and are lined by coarse, zoned, well terminated quartz crystals and minor amounts of purple fluorite.

The gray, porphyritic microgranite dikes southwest of the mountain are generally vertical, 0.5 to $1.5 \mathrm{~m}$-thick, and form a swarm that is crudely radial to the center of the complex. They are characterized by 40 to 50 percent phenocrysts $(1$ to $2 \mathrm{~cm}$ in diameter) of quartz, orthoclase, and albite in approximately equal proportions (fig. 6). Albite phenocrysts have a broad margin of myrmekitic intergrowths with quartz. The matrix is a very fine grained, granular intergrowth of anhedral quartz and feldspars and contains minor amounts of magnetite, apatite, and zircon.

\section{SANIDINE PORPHYRY}

A regional swarm of vivid orange-red dikes, 2 to $5 \mathrm{~m}$ thick, is composed of richly porphyritic, weakly peralkaline rhyolite (Cole, 1984b) and is defined as the Sanidine porphyry unit for the abundance of sanidine, quartz, and albite phenocrysts (Cole, this report). The dike swarm has a consistent N. $50^{\circ}$ E. trend for a distance of more than $80 \mathrm{~km}$ and extends beyond the Uqlat as Suqur quadrangle to the northeast and the southwest. Sanidine porphyry dikes are not of fet across the Ata, Shara, or Rumah faults and they are compositionally similar to the weakly peralkaline Humaliyah formation volcanic rocks (Cole, 1984b). For these reasons, the unit is correlated with the Abanat suite and is inferred to have been emplaced $585 \mathrm{Ma}$ to $570 \mathrm{Ma}$ ago (Cole, 1984c, prostuckless and others, 1984).

Dikes of the Sanidine porphyry unit are easily identified by their distinctive color, their substantial thickness, and because of resistant ridges (20 to $40 \mathrm{~cm}$ thick) along their margins produced by weak contact metamorphism. From the northeast, a singular dike broadly follows the trend of the Ata fault from Dulayat al Agharr to the southern bank of Wadi ar Rumah. Southwest and west of this drainage channel, five distinct dikes and dike swarms are mapped between the north slope of Jabal al Idayri and haib Amayir Siidah, and these swarms are spaced about 6 to $9 \mathrm{~km}$ apart. The 
northernmost swarm can be traced westward for an additional $20 \mathrm{~km}$ (Cole, this report) where it terminates near the alkalic granite ring-dike intrusion at Jabal Daym (Brosset and Delfour, 1972).

Sanidine porphyry typically contains 30 to 50 percent phenocrysts of sanidine, albite, and quartz (5:3:4 proportions) in a fine-grained groundmass of blocky feldspars and anhedral quartz. Euhedral sanidine crystals and glomerophenocrysts of sanidine and albite are generally 8 to $12 \mathrm{~mm}$ in diameter, whereas quartz grains (euhedral, slightly embayed) are 2 to $3 \mathrm{~mm}$ in diameter. Feldspars are very weakly zoned, but are locally surrounded by a wide, granophyric envelope. Sanidine is not perthitic and displays characteristic, slightly anomalous birefringence in sections sub-parallel to an optic axis.

Biotite (rare phenocrysts and ragged groundmass grains) makes up less than 5 percent of the rock and has an odd but distinctive dark-green to yellow-green pleochroism. Minor amounts of magnetite, apatite, and zircon are present, commonly as inclusions in biotite. Bastnaesite is tentatively identified from one sample of the northernmost dike, based on very high relief, moderate birefringence, brown color, parallel extinction, and hexagonally symmetric, planar hematite inclusions. Other rare-element minerals may also be present.

Alteration is restricted to dispersed hematite granules in feldspars and biotite, and to sparse sericite in albite and sanidine. Radial aggregates of white mica form irregular patches in the groundmass that may have been primary voids. 


\section{STRUCTURAL UNITS}

The trace of the Ata fault in the eastern part of the quadrangle is discontinuously marked by the presence of pervasively deformed rock. The Serpentinite and Cataclastic megabreccia units are defined on the basis of structural style and on internal lithologic heterogeneity characteristic to each. These rock units have no stratigraphic context because they are wholly bounded by surfaces of dislocation.

\section{SERPENTINITE}

Two elongate bodies in the vicinity of Dulayat.al Agharr, each about $2 \mathrm{~km}$ long and several hundred meters wide, consist chiefly of serpentinite (sp) derived from ultramafic rock. The western body coincides with the mapped trace of the fault (boundary between metamorphosed Dhiran meta-andesite and nonmetamorphosed Murdama sandstone), but the eastern body lies $1.2 \mathrm{~km}$ south of the main trace in the Dhiran and may mark the location of a subsidiary trace. Serpentinite is black to dark green in outcrop and forms low ridges that are covered with dense desert varnish. Slickenside lineations are common on joint surfaces and have diverse orientations.

The unit consists chiefly of cataclastically foliated serpentinite that forms the matrix for numerous lensoid blocks (several centimeters to as much as $10 \mathrm{~m}$ in diameter) of diverse lithologic types that are also cataclastically foliated. Foliation in the lensoid blocks is planar and pervasive but its orientation is not conformable from block to block; foliation in the serpentinite matrix, however, is more uniformly parallel to the trace of the Ata fault and dips $50^{\circ}$ to $80^{\circ}$ to the northwest. The most common rock types in the lensoid blocks are Dhiran meta-andesite, Suwaj-type diorite, and felsic plutonic rock (uncertain protolith).

The serpentinite matrix consists chiefly of fibrous to granular serpentine-group minerals, granular magnetite, traces of talc and tremolite, and dispersed, fractured grains $(0.5$ to $1.0 \mathrm{~mm}$ in diameter) of dark red-brown spinel. In samples that are not pervasively foliated, the textures of the serpentine minerals and the granular magnetite suggest that most of the original minerals were olivine, although locally as much as 5 percent were (ortho?)pyroxene. Thus, dunite and harzburgite are interpreted to have been the ultramafic protoliths.

The cataclastic foliation in the serpentinite matrix is defined by bent and aligned (recrystallized) serpentine fibers and by trails of granular magnetite. These observations suggest the ultramafic protoliths were converted to serpentine minerals prior to emplacement in the Ata fault. Post-emplacement alteration is locally intense, as indicated by irregular patches and rhombic porphyroblasts of dolomite and by hematitic alteration of magnetite.

The rocks in the lensoid blocks are also intensely altered to assemblages of epidote, calcite, and chlorite. This alteration is also interpreted to postdate major movement on the fault because the alteration minerals are undeformed and they replace the foliated rock fabric. The boundary between crushed and granulated rock (original minerals) and the undeformed alteration-assemblage minerals follows the trace of foliation seams and indicates preferrential alteration of the most thoroughly deformed zones. 


\section{CATACLASTIC MEGABRECCIA}

The trace of the Ata fault at the eastern border of the Uqlat as Suqur quadrangle is defined by elongate masses of the Cataclastic megabreccia unit (mbr), which extend along the trace in the adjoining quadrangle (Cole, 1984c). The outcrop of the megabreccia is dominated by blocky, lensoid, fractured knobs (meters to tens of meters long) that consist of diverse, altered and cataclastically foliated rocks. The poorly exposed matrix to these blocks is serpentine-rich, locally foliated, and generally dips steeply toward the north.

Cataclastic megabreccia is structurally gradational with the Serpentinite unit and is distinguished by the greater size and abundance of exotic blocks (typically 70 to 80 percent of the outcrop area). The textural, mineralogical, and structural features are equivalent in the two units. The Cataclastic megabreccia unit contains a wider variety of exotic materials, including quartz-bearing fine sandstone that may have been derived from the Murdama. This sandstone contains ptygmatically folded and dismembered veins of granular quartz, and the textural features indicate that veining was followed by flattening and dislocation on foliation planes, which was in turn followed by static replacement by calcite, chlorite, and epidote. 


\section{QUATERNARY DEPOSITS}

Mapped units of Quaternary age cover approximately 10 percent of the Uqlat as Suqur quadrangle and have been distinguished chiefly on the basis of composition, mode of occurrence, and on implied relative age. The framework for the description and interpretation of these deposits derives from the regional studies and carbon-14 age-dating by. Whitney (1983 3 date). Thin, oxidized soil horizons in fans and alluvial aprons and in terrace deposits indicate that they probably formed during the Pleistocene Epoch, whereas channel alluvium and saline deposits in playa basins are chiefly Holocene deposits. Eolian sand of the Nufud al Urayq dune field is exposed only in the southeastern quadrangle corner, and is interpreted to have accumulated during several episodes throughout the Quaternary Period.

\section{ALLUVIAL FAN AND APRON DEPOSITS}

Irregular deposits of gravel, sand, and boulders form alluvial fans and aprons (Qf) at the bases of many of the high mountain masses of the quadrangle. In most localities, these deposits extend less than a kilometer downslope from the source area and do not materially obscure the bedrock geology. Only the extensive deposits surrounding Jabal Timiyah and Jibal Qitan are mapped with this unit.

The surfaces of alluvial fans and aprons are covered. with angular clasts and lag gravel that are typically coated with desert varnish, although those at Iblat Qitan lack varnish because of the iron-poor source rocks in the Qitan complex. Modern drainage across the fans and aprons is confined to narrow, discontinuous channels that are slightly incised (less than a few meters near the heads of fans) and flanked by gravel and boulder levees. These channels and rutted desert tracks locally expose a discontinuous red-orange horizon of slightly cohesive soil.

Whitney $\left(\frac{1983}{d 26}\right)$ concludes that these oxidized, clayey soils are unknown in this part of the Arabian Shield in deposits younger than 30,000 to 35,000 years B.P. (before present). The mass-wasting, erosion, and runoff indicated by the Alluvial fan and apron deposits probably reflect periods of increased precipitation, vegetation, and chemical weathering during the Pleistocene Epoch, chiefly during the interglacial intervals in the northern hemisphere (Whitney, 1983, uncul-dato, p. 77).

\section{TERRACE GRAVEL DEPOSITS}

The major drainage channels of the quadrangle are flanked by terrace gravel deposits $(\mathrm{Qt})$ that are 0.5 to $2.0 \mathrm{~m}$ above the modern drainage bed. These deposits are thickest and most widespread along the margins of Wadi ar Rumah (the trunk channel for most of the drainage in the northeastern Shield; fig. 1), but are also common along Shaib Mutribah and Wadi al Jarir (south of this quadrangle; Young, 1982). The significance of the absence of terrace deposits along Wadi al Mahalani is unknown.

Terrace gravel deposits are dark brown, black, and locally orange-brown and are covered with a lag deposit of well rounded to subangular cobbles and pebbles. Most of these clasts consist of durable vein quartz, red felsic volcanic rock, and dense aphanitic material that are rare in this quadrangle and were probably derived from more distant sources. Red-orange, oxidized, clayey soil is typically present within these deposits at a depth of several tens of centimeters and is exposed in vehicle and camel tracks and on 
the margins of the terraces. Terrace deposits are easily distinguishable from other surficial materials because they are soft and spongy due to aeration by capillary groundwater movement, and saline encrustations are common where this water evaporates.

The extent and character of the soil horizon in the Terrace gravel deposits is similar to that in the Alluvial fan and apron deposits, and they are also interpreted to have formed during periods of increased rainfall and runoff in the Pleistocene Epoch (Whitney, 1983, umpub. dataj.

\section{EOLIAN SAND DEPOSITS}

Large accumulations of wind-blown sand ( $Q e)$ in the southeastern corner of the quadrangle are contiguous with the extensive Nufud al Urayq dune field to the east and south (Cole, 1981, 1984c, prew). Most of this sand forms large, inactive, sparsely vegetated, barchanoid-cluster and star dunes whose crests are locally as much as $100 \mathrm{~m}$ higher than the bedrock surface exposed in the deflated interdune areas. These large dunes have an overall gray color due to a surface lag of medium- to coarse-grained quartz-feldspar sand. Smaller, active, barchan and barchanoid dunes on the flanks and summits of these gray dunes are typically red or red-orange and consist chiefly of fine sand that contains a higher proportion of unstable iron-bearing minerals. Thin blankets of sheet sand are mapped with this unit in the area surrounding Jabal Idah, but also comprise part of the thin surficial cover (not mapped) at Iblat Qitan, Al Khullah, and Darat Ata.

Calcareous and gypsiferous lakebed marls are locally preserved in the interdune areas of Nufud al Urayq in adjoining quadrangles (Cole, 1981, 1984c). Local stratigraphic relations and carbon-14 ages indicate these marls formed chiefly during two wet periods, 33,000 to 22,000 years B.P. and 9,000 to 5,000 years B.P. (Whitney, 1983 , wa p. 71). Most of the sand (in the inactive gray dunes) probably accumulated during the arid, glacial intervals of the Pleistocene Epoch and the older lakebeds reflect increased precipitation during the latest Pleistocene interglacial; the younger lakebeds formed early during the Holocene Epoch and, since that time, only the smaller, red dunes have been active (Whitney, prew: Cole, this report).

\section{SABKHAH DEPOSITS}

Light-colored, bedded, saline silt deposits and saline encrustations (Qs) are common in the Uqlat as Suqur quadrangle, particularly in rock-sheltered hollows adjacent to the major drainage channels. The thickness of these deposits is unknown but is estimated to be less than one meter. Most of the material consists of fine silt that is loosely cemented by unidentified chemical precipitates (probably carbonate and sulfate minerals).

The process of sabkhah formation continues at present due to evaporation of rainwater and groundwater, but the main period of formation probably coincided with the Holocene wet interval ( 9,000 to 5,000 years B.P.; Cole this report). The fact that uneroded sabkhah deposits cover several subsidiary drainage channels (Shaib al Wudayy, Shaib adh Dhiran, and others) where they join Wadi ar Rumah indicates that the deposits chiefly accumulated since the last period of increased runoff. 
The most voluminous surficial deposit in the quadrangle consists of sand, gravel, and silt $(Q)$ in the modern drainage channels. The thickest deposits are most likely beneath Wadi ar Rumah and Wadi al Jarir because they have the largest drainage basins (fig. 1), but the common exposure of bedrock in these channels indicates that alluvium is probably no more than a few meters thick. Most alluvium is inactive at present, and sparse modern runoff is carried by braided rivulets that transport debris no more than a few hundred meters downstream before the discharge is absorbed in the streambed. Channel gradients are very low as a result of steady aggradation that has been typical since the latest Pleistocene interval of higher discharge (Cole, this report). 


\section{STRUCTURAL GEOLOGY}

The deformational history of the rocks of the Uqlat as Suqur quadrangle is recorded by folds, pervasive schistosity and lineation, faults, and by the relation of these elements to the major unconformities that separate the layered-rock units. Folds of various styles, scales, and orientations are widespread in the Murdama group whereas simpler and more uniform folds characterize the Jurdhawiyah group. Pervasive schistosity and lineation are chiefly restricted to the fault-bounded Ata-Shara block (fig. 3). Faults of diverse trend and inferred slip direction are common in the quadrangle, and their history of movement can, in many cases, be constrained by their relation to layered and intrusive rock units.

\section{FOLDS}

Folded bedding is common in the layered rocks of the Murdama and Jurdhawiyah groups, but no folds possess associated axial-planar schistosity or mineral lineation. Folded schistosity has only been recognized in one locality within the Ata-Shara block where it is genetically associated with a high-angle reverse fault. With the exception of a few centimeter-scale flexures and isoclines, no folds have been identified within the rocks of the Dhiran meta-andesite, and their absence is probably due to the structural competence of the rock and to its lack of well defined bedding.

Fold wavelengths within rocks of the Murdama group span the entire range from several centimeters to tens of kilometers. The largest folds are north-trending structures in the Mahalani and Maraghan basins (fig. 3) that are characterized by open, concentric geometry. In the western part of the Ata-Shara block, the dominant folds in the Murdama are nearly isoclinal and trend in a westerly direction, due to later re-orientation. Folds with wavelengths of less than about one kilometer are far more irregular and disharmonic, and are not geometrically related to the regional fold patterns (for example, in the vicinity of Darat Ata across the Bakrah arch; fig. 3, pl. 1). Outcrop-scale folds are also common within the Murdama and they range from open and concentric, to tight, to isoclinal and rootless and are generally not geometrically related to larger folds in the vicinity.

Murdama limestone contains particularly widespread folds that are well exposed in the area of Jibal ash Shuhban. The major folds have wavelengths of 1 to $2 \mathrm{~km}$ and they plunge gently toward the west, as do the major folds in the adjoining Sandstone unit of the Murdama. Outcrop-scale folds, however, are extremely diverse in style and orientation and are not generally coaxial or concordant with the major structures, nor do they appear to be geometrically related to the faults in this area.

Kilometer-scale, tight but upright folds are well defined in the western part of the Ata-Shara block (designated the Al Jimariyah area) by the outcrop trace of the Felsophyre member of the Murdama sandstone. The orientation of bedding for this unit in the fold limbs defines calculated axes that plunge gently toward the west (fig. 7). However, these west-trending folds are modified along the western quadrangle boundary by interference with north-trending folds that characterize the Murdama to the west (Brosset and Delfour, 1972; Cole, this report), and the orientation of bedding defines dome-and-basin patterns (for example, $3 \mathrm{~km}$ west of Al Jimariyah; pl. 1). This pattern of interference folding appears to extend as far north and west as the Ar Rahadah batholith (fig. 3; Cole, this report), and analysis of bedding attitudes (not shown on fig. 7) indicates that the dihedral angle between the interfering fold trends is about $70^{\circ}$. 


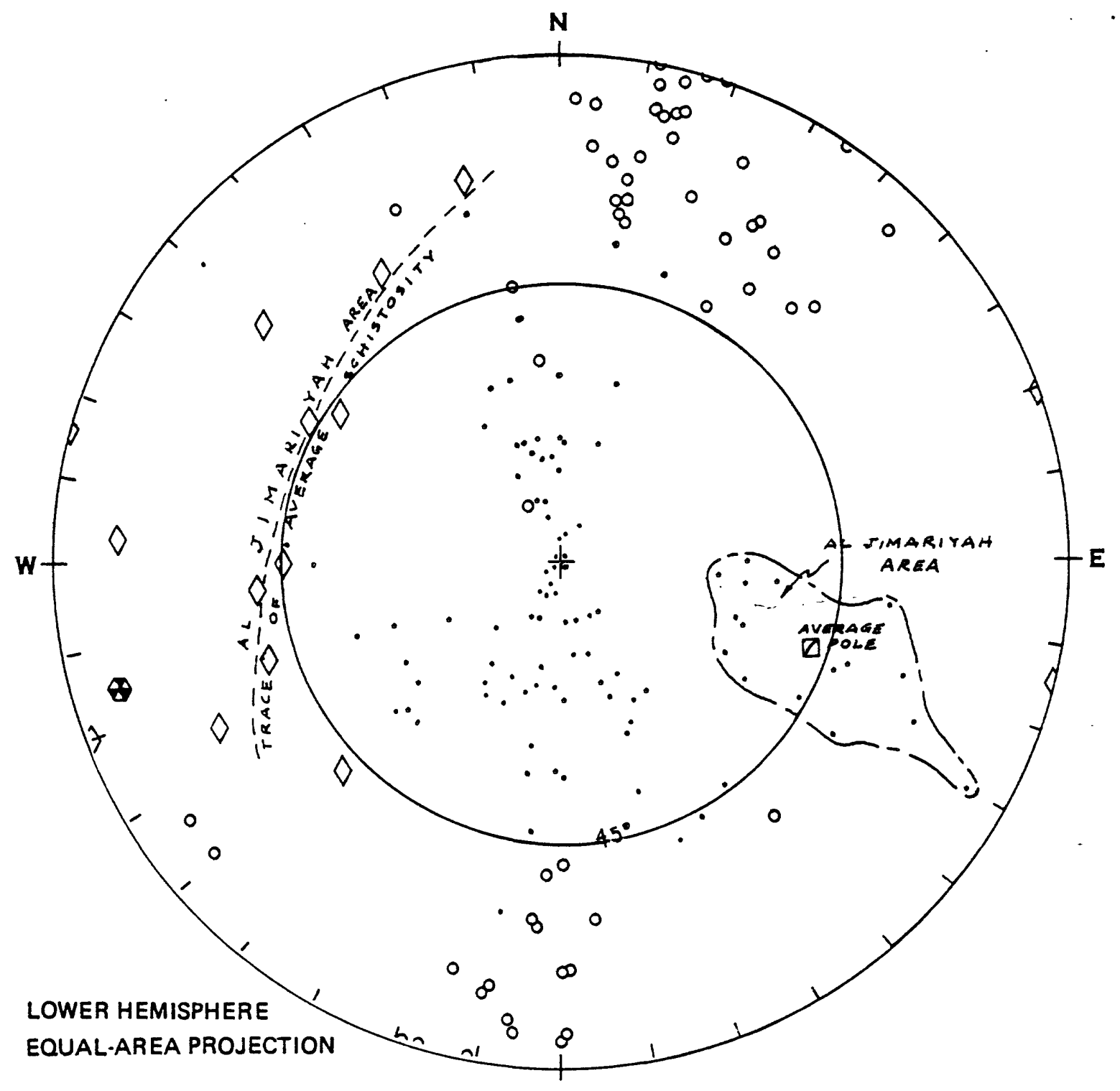

AL JIMARIYAH AREA (see text)

$\triangle$ Calculated fold axis

$\square$ Pole to average schistosity

- Pole to schistosity (98)

- Elongation lineation (53)

$\checkmark$ Schistosity-bedding

intersection (13)

Figure 7.--Stereogram of structural data for deformed rocks in the Ata-Shara block. Tick-marks on outer circle at $10^{\circ}$-arc intervals; inner circle at $45^{\circ}$ plunge. Number of measurements indicated in parentheses. 
In contrast to the diversity of style, scale, and trend of folds in the Murdama, those in the Jurdhawiyah group are open, upright, chevron-style flexures that plunge gently eastward in the eastern part of the Idayri basin and plunge gently westward in the western part of the basin (fig. 3). Four of the five major folds are synclines, and this bias is probably due to the original synformal shape of bedding surfaces in the depositional basin. Jurdhawiyah folds are generally parallel to the high-angle reverse faults of the Lughfiyah-Shuhban system and, for example near the village of Al Maylih and at Jabal Timiyah, sets of smaller chevron folds in the footwall are parallel to the faults, and fold amplitude diminishes a way from the slip surface.

The larger folds in the Jurdhawiyah group have wavelengths on the order of several kilometers and estimated amplitudes of about one kilometer. The hinge zone is generally defined by an abrupt reversal in the dip of bedding (rather than by a hingezone closure) due to the gentle plunge and chevron style of the folds, and several fold hinges pass along strike into high-angle faults. The syncline in the western Idayri basin is such a structure and the faults at its eastern and western ends are marked by cataclastic rock, stratigraphic offsets, and by magnetic lineaments (Cole, this report). A puzzling aspect of this structure is that the synclinal hinge (which contains no cataclastic rock and does not coincide with a magnetic lineament) appears to be a fault because it locally marks the eastern end of beds of the Lapilli tuff member, although distinctive beds of conglomeratic Volcaniclastic sandstone can be traced continuously through the hinge-zone flexure.

\section{PERVASIVE SCHISTOSITY AND LINEATION}

Rocks of the Dhiran meta-andesite and the Murdama group are intensely deformed and characteristically schistose within the fault-bounded Ata-Shara block (fig. 3). Jurdhawiyah group rocks south of the Shara fault and most of the Murdama north of the Ata fault are nonschistose, and so the unique deformation and metamorphism within the block must be related to the history of the structural boundaries. The schistosity is inferred to have formed prior to final deposition of the Jurdhawiyah group in the Idayri basin because schistose clasts are common in the Shara conglomerate and in the Jurdhawiyah sandstone on the north side of the basin.

Schistosity is defined by aligned chlorite and muscovite and by the shape of deformed cobbles in the Timiriyat conglomerate, and a penetrative lineation it typically defined by major axes of ellipsoidal clasts and (locally) by the intersection of anastomosing schistosity planes. Schistosity in the Ata-Shara block defines a broad arch (fig. 3, 7) and is typically sub-horizontal along the central axis, but the dip becomes progressively steeper in proximity to the bounding Ata and Shara faults, and dips away from the block at $50^{\circ}$ to $80^{\circ}$ where it merges with the faults. The contained lineation trends uniformly north-northeast and south-southwest across the arch (fig. 7), regardless of the dip of the schistosity.

The deformation and the related schistosity and lineation are most intense in the central portion of the Ata-Shara block, approximately between long $42^{\circ} 10^{\prime} \mathrm{E}$. and $42^{\circ} 27$ ' E. To the east, the trend of schistosity defines a domal closure parallel to the change in strike of the Ata fault (fig. 3; Cole, 1984c), and it becomes progressively weaker in the competent rocks of the Dhiran meta-andesite. To the west, the trend of schistosity also defines a closure and it becomes weaker toward the western quadrangle boundary. In the Al Jimariyah area where Murdama sandstone and felsophyre define west-trending folds, this schistosity crosses bedding at a high angle, of fets bedding surfaces, and is also formed in the felsic rocks of the Deformed and altered dike unit. 
Schistosity clearly post-dates the folding and emplacement of these dikes, as indicated by its uniform trend, by the scatter of schistosity-bedding intersections in the average schistosity plane, and by the lack of correlation between these lineations and the Murdama fold axes (fig. 7).

Barren quartz veins (containing granular chlorite, brown carbonate, and specular hematite) are widespread in the Ata-Shara block and are genetically related to the formation of schistosity and lineation. Veins are most abundant in the more competent materials (felsic dike rocks, the Felsophyre member of the Murdama, and plutonic-rock clasts in the Timiriyat conglomerate) and are typically perpendicular to the clastelongation lineation. Within the west-trending felsic dikes and Felsophyre beds, however, most quartz veins are subvertical and trend consistently toward the north-northwest, and this geometry suggests the tabular, competent bodies fractured and extended along the axis of the Ata-Shara block in response to the dominantly horizontal flattening strain.

\section{FAULTS}

Numerous faults mapped in the Uqlat as Suqur quadrangle are interpreted to represent three major fault systems: the east-trending Ata-Shara fault system, the east-trending Lughfiyah-Shuhban fault system, and the northwest-trending Rumah fault system (fig. 1). These faults are mapped on the basis of exposed cataclastic rock and cataclastic-rock float, on stratigraphic offsets and displaced structures, and on magnetic lineaments and gradient zones. Fault surfaces are rarely exposed, but offsets and displacements can be demonstrated for all faults shown on the-map, and most fault traces coincide with linear magnetic features. Faults depicted by a long-short dashedline symbol ("inferred from magnetic data") are probably real because they are required to satisfy the local geometric constraints of structure and stratigraphy, but the indicated fault trace beneath surficial cover was based solely on linear magnetic features.

Stratigraphic and structural of fsets require that most of these faults are dip-slip structures. Major lateral (strike-slip) offset that is typical of the Halaban-Zarghat fault (fig. 1), for example, is precluded by this evidence for faults in the Uqlat as Suqur quadrangle. Principal periods of movement on the fault systems in the Uqlat as Suqur quadrangle cover an extended span of time that may have begun with Murdama deposition and lasted until the deposition of Saq Sandstone early in the Cambrian Period (approximately $670 \mathrm{Ma}$ to $570 \mathrm{Ma}$; Cole, in prew; Cole and Hedge, 1984, unpub. data). Some of this movement was very likely contemporaneous with episodes of lateral displacement on the Halaban-Zarghat fault $25 \mathrm{~km}$ southwest of this quadrangle (fig. 1), but the relations among these faults in space and time have not yet been established.

Segments of the Ata-Shara and Rumah fault systems were probably active along the margins of Murdama depositional basins, because they appear to have controlled uplift of the Dhiran-Suwaj terrane and the depositional trend of the Timiriyat conglomerate. A second major phase of movement on the Ata-Shara and Rumah systems coincides with the principal movement on the Lughfiyah-Shuhban system, which is interpreted to have partially overlapped with deposition of the Jurdhawiyah group in the Idayri basin. Several east-west faults in the area between Shaib al Humaliyah and Al Jimariyah were chiefly active in latest Proterozoic time, following deposition of the Humaliyah formation. 
Figure 8 illustrates the fault systems of this quadrangle and defines the designations used in this report. The map (fig. 8A) shows the distribution of faults, the sense of displacement as required by stratigraphic evidence (where known), and the

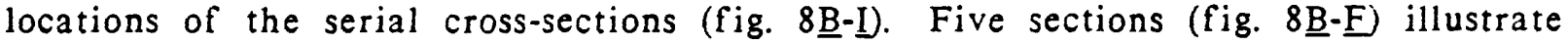
west-to-east slices through the Lughfiyah-Shuhban fault system, and are aligned on the position of the surface trace of the Lughfiyah fault. The Ata-Shara system is illustrated in three slices (fig. $8 \mathrm{G}-\mathrm{I}$ ) that are aligned on the surface trace of the Shara fault. Cross-sections E-E' (fig. 8E) and I-I' (fig. 8I) are segments of section A-A' on the geologic map (pl. 1). The letter-number designations of major and subsidiary fault traces are based on geographic area and are only used to simplify the following description; they do not necessarily imply geometric or genetic relationships.

\section{Ata-Shara fault system}

The Ata and Shara faults are interpreted to have shared a common history because they largely bound the uniquely deformed rocks of the Ata-Shara block, they have a similar trend across most of the quadrangle, and they bear similar relations to the structures and stratigraphy within the block. The Ata fault differs somewhat because it contains cataclastic megabreccia, serpentinite, and listwänite (Cole, 1984c) along parts of its trace, and it may have had an independent history prior to formation of the Shara fault. A sharp magnetic boundary coincides with the eastern trace of the Ata fault, but the magnetic signature of both the Ata and Shara faults west of Wadi ar Rumah is weaker and expressed only by subtle magnetic contrasts.

The schistosity within the Ata-Shara block changes orientation in proximity to the traces of both of the bounding faults, and is parallel at the margins of the block. Cataclastic fluxion structure in the exposed Ata fault is parallel to the local schistosity, and it is inferred that a similar relation applies along the length of both faults. Thus, the Ata fault dips $60^{\circ}$ to $70^{\circ}$ toward the north and the Shara fault dips $60^{\circ}$ to $75^{\circ}$ toward the south, but the sinuous fault traces suggest dips are variable along both.

Both the Ata and Shara faults are inferred to have had complex histories marked by several periods of movement, and the sense of displacement was not the same during each period. The present net displacement on both structures is chiefly normal, as indicated by the fact that the Dhiran-Suwaj terrane and the Timiriyat conglomerate (basal Murdama) in the Ata-Shara block are structurally higher than the Murdama and Jurdhawiyah groups in the hanging-wall blocks. However, the Ata fault immediately west of Uqlat as Suqur town seems to have net reverse of set because pre-Murdama granodiorite granophyre (Suwaj suite) is juxtaposed in the hanging-wall against Timiriyat conglomerate in the footwall.

The Ata fault may have initially formed as a wrench fault during emplacement of the Suwaj suite (Cole, 1984c, pres)but evidence for its earliest history in this quadrangle is related to the beginning of Murdama deposition. The Ata fault east of Wadi ar Rumah forms the northern boundary for the Dhiran-Suwaj terrane, which was most likely uplifted to provide coarse clastic debris to the Timiriyat conglomerate. The Ata west of Wadi ar Rumah and the A2 fault (fig. 8a) form the principal northern boundaries for an unusually thick section of Timiriyat that was probably deposited in a graben between these faults and the Shara fault. This graben was an active site for deposition of coarse clastic debris in the Murdama over an extended period of time, as indicated by the persistence of Timiriyat conglomerate along this trend westward to higher stratigraphic levels, where it is at least $5 \mathrm{~km}$ thick (Sumar al Hasat area). 


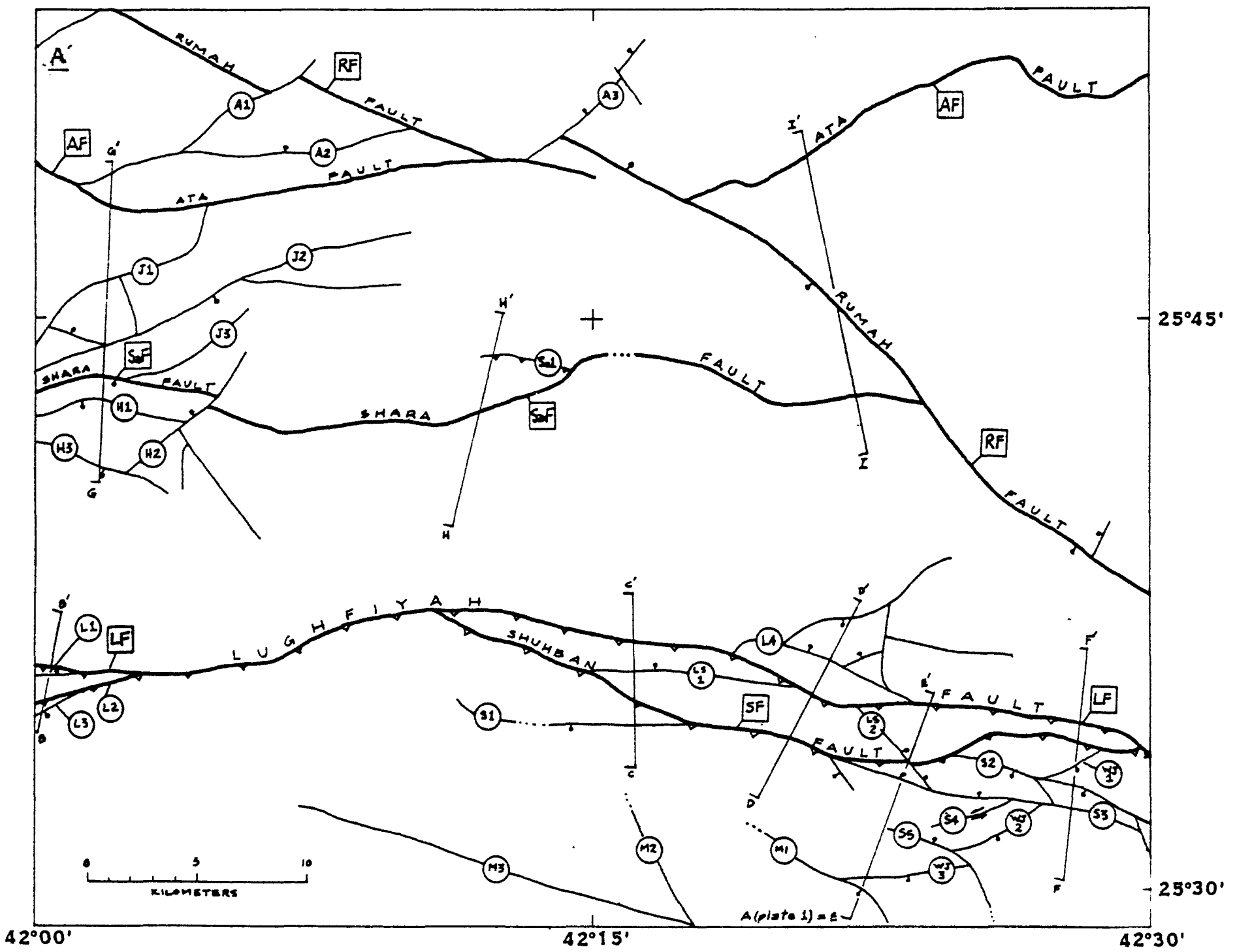

Figure 8.--Faults and fault relationships in the Uqlat as Suqur quadrangle. 8A). Map showing faults in the southern two-thirds of the quadrangle, and locations of cross-sections. 8B through 8I). Geologic cross-sections for section lines $B-B^{\prime}$ throuth $I-I^{\prime}$. All sections face westward; 1:100,000-scale (horizontal and vertical); true-scale section lines plotted on Plate 1. Explanation of symbols follows fig. $\underline{81}$; dikes and veins omitted for clarity. 


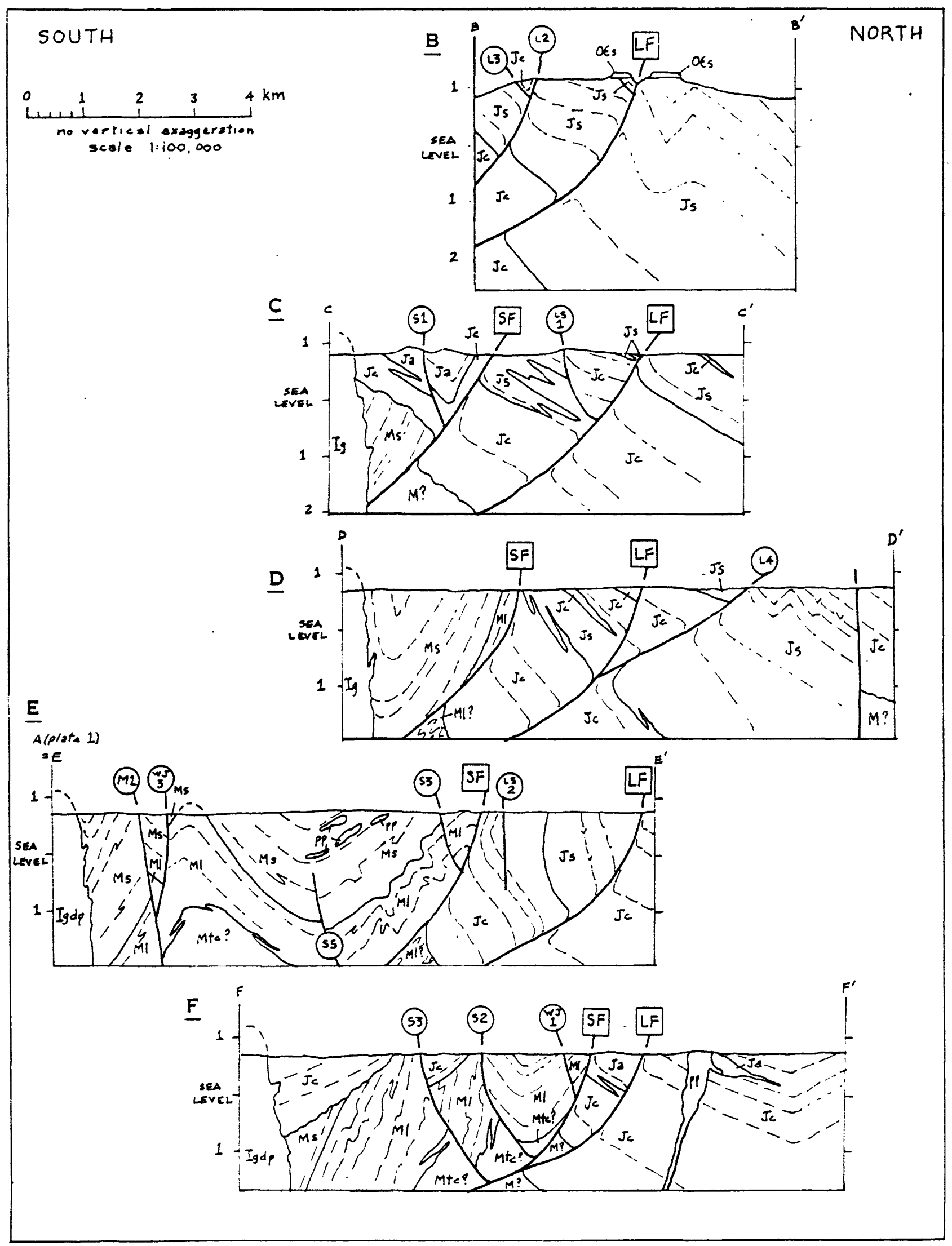

Figure 8.--Faults and fault relationships (Continued) 


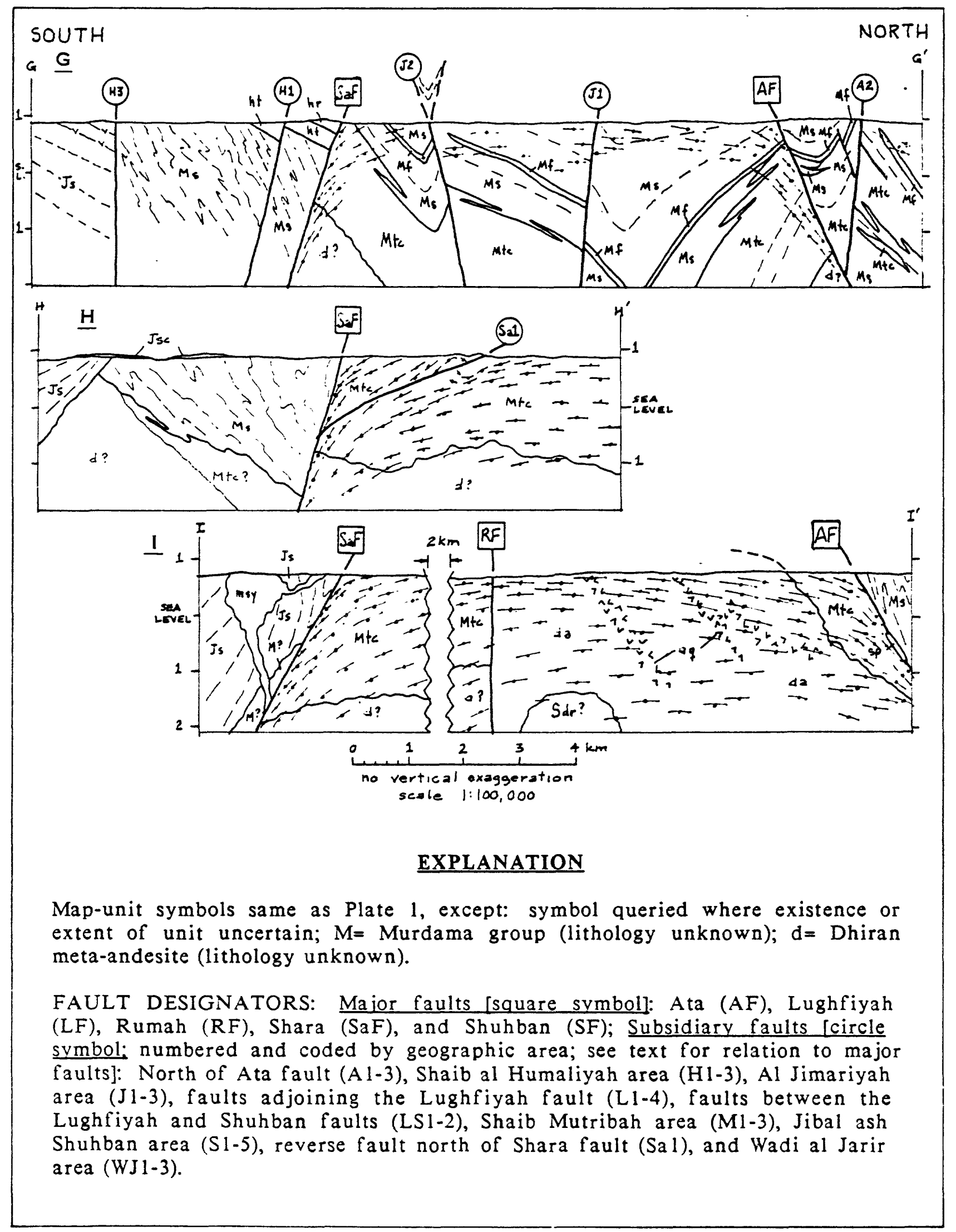

Figure 8.--Faults and fault relationships (Continued) 
The Timiriyat must be substantially thinner (or non-existent) outside the proposed graben, and its widespread exposure in the Ata-Shara block cannot be explained simply by differential uplift of the Murdama base. Sandstone marginal to the graben contains abundant shallow-water limestone that implies the base of the Murdama is probably less than a kilometer below the present surface. This conclusion is supported by magnetic data (ARGAS, 1967) across the Bakrah arch that indicate the top of the (magnetic) Dhiran-Suwaj terrane is near the surface (Cole, this report). The amount of displacement on the Ata and Shara faults during the time this graben was active could be as great as the thickness of the Timiriyat, but was probably less because basin-wide subsidence also added to the structural relief.

The Ata fault was clearly re-activated following regional folding of the Murdama because it truncates these folds, particularly north of Dulayat al Agharr. The sense of offset along the entire trace of the fault was down-to-the-north, as indicated by the juxtaposition of Murdama sandstone north of the fault against Dhiran-Suwaj terrane and (basal Murdama) Timiriyat conglomerate. The Ata fault west of Wadi ar Rumah, therefore, reversed its sense of displacement during the second major phase of movement, in which the Ata-Shara block was uplifted and eroded to shed debris southward to the Shara conglomerate (Jurdhawiyah group). The total uplift during this phase was probably greater than the total subsidence during the first phase because the inferred base of the Murdama within the Ata-Shara block is presently at a higher position than it is marginal to the block (fig. $8 \underline{\mathrm{H}}$, I; section $\mathrm{A}-\mathrm{A}$, pl. 1 ).

The Shara fault juxtaposes schistose Murdama rocks to the north against non-schistose Murdama sandstone and Jurdhawiyah-group rocks to the south along most of its length. The history of movement on the Shara is interpreted to be similar to that described for the Ata fault west of Wadi ar Rumah. Its displacement was down-to-the-north during deposition of Timiriyat conglomerate in the graben, but changed to down-to-the-south during formation of the Idayri basin (Jurdhawiyah group) and the uplift of the Ata-Shara block. This later phase of movement was accompanied by local, northward-directed compression, as indicated by the Sal fault (fig. $\mathbf{8} \underline{\mathrm{A}}, \underline{\mathrm{H}}$ ). This subsidiary reverse fault is a discrete surface of slip (less than a few centimeters thick) that offsets a local fold pair in the schistosity of the Ata-Shara block. The geometry of these folds, the Sal fault, and minor crenulations in schistosity near the fault indicate that all formed in response to the same stresses.

Movement on the Shara fault in the section between the Rumah fault and the $\mathrm{H} 2$ fault (fig. $8 \mathrm{~A}$ ) appears to have ended shortly after Jurdhawiyah deposition because it is intruded by a plug of Sodic microsyenite. Movement on the Ata fault probably ended at the same time, although its last displacements are only known to pre-date the Sanidine porphyry dikes (Abanat suite; Cole, 1984c, phen).The Shara fault west of the H2 fault was re-activated as a down-to-the-south normal fault (fig. 8G) following deposition of the Humaliyah formation (thus, post-Abanat suite; Cole, this report). The $\mathrm{H} 1, \mathrm{H} 2$, and $\mathrm{H} 3$ faults in this area (fig. 8A) also displace the Humaliyah and were probably active at the same time. Other subsidiary faults near the western quadrangle boundary ( $\mathrm{A} 1, \mathrm{~J} 1$, and $\mathrm{J} 3$; fig. $8 \underline{\mathrm{A}}, \underline{\mathrm{G}}$ ) may also represent post-Humaliyah fracturing because they are not intruded by Sanidine porphyry dikes. However, the A2 and J2 faults pre-date these dikes and may have formed during east-west folding of the Murdama group, as suggested by the observation that the J2 fault partially coincides with the flexure between folds in the Murdama (fig. 8ㅁ; pl. 1). 


\section{Lughfiyah-Shuhban fault system}

Faults in the southern part of the quadrangle that chiefly trend east-west are interpreted to consist of two master, high-angle reverse faults and numerous subsidiary faults that formed at the same time. The master Lughfiyah and Shuhban faults dip steeply toward the south at the surface, but are interpreted to curve, flatten, and join at depth (fig. 8B-F). The sense of displacement is determined by overturned beds beneath the faults, by stratigraphic offset, and by minor structures formed near the fault planes. The amount of of fset on the master faults is not known precisely, but the geometric projection of surface data (fig. 8ㅁ-ㄷ) indicates an aggregate Murdamaover-Jurdhawiyah displacement of several kilometers.

The subsidiary faults of the Lughfiyah-Shuhban system are chiefly high-angle normal faults and minor rotational and tear faults that terminate in the master faults, and most of them are in the plates above the master reverse faults. Stratigraphic offsets suggest that displacements are on the order of tens to a few hundred meters. Subsidiary faults that have down-to-the-north displacements (as do the master faults) form the boundaries of homoclinally tilted blocks of layered rock (L1, LS1, and S3 faults; fig. 8A, $\underline{B}, \underline{C}$ E). Those subsidiary faults that have down-to-the-south displacements (antithetic to the master faults) form the boundaries of synclinally

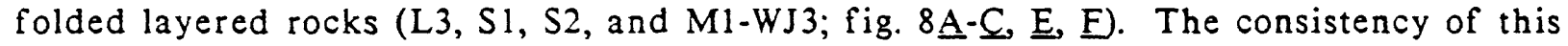
relationship indicates that the major folds in this area formed during fault movement. The fault-bounded blocks that contain synclines appear to have warped as they were moved (upward) away from the master-fault surfaces, whereas the blocks of homoclinal rock were moved (downward) toward the fault surface and were not folded.

Several subsidiary faults south of the Lughfiyah fault require a component of rotational slip, and the net effect of this type of movement has been to rotate several fault-bounded blocks down-to-the-west. This relationship is indicated by the general westward plunge of folds in the Murdama and by the S2 fault, whose displacement is down-to-the-south in this quadrangle but changes progressively to down-to-the-north several kilometers to the east (Cole, 1984c).

Down-to-the-west rotation of large, fault-bounded slabs apparently became mechanically impossible at some stage, and the WJ1-3 fractures appear to have fragmented the large slabs and allowed the smaller pieces to continue rotation. The repetition of the west-plunging syncline between the $S 2$ fault and the Shuhban fault (fig. $8 \mathrm{~A} ;$ pl. 1) is a result of down-to-the-east offset on the WJl fault. Similar offsets are deduced for the WJ 2 and WJ 3 faults from the deeper stratigraphic levels exposed west and north of the faults. A different style of accommodation is indicated by the block bounded by faults S2, S3, LS2, and an unnumbered fault in Wadi al Jarir that encloses a reclined syncline in the Murdama limestone. Assuming an original horizontal fold axis, this block has been rotated $115^{\circ}$ down-to-the-east, in the contrary sense to the other rotated blocks.

Faults and folds north of (beneath) the Lughfiyah fault near the town of $\mathrm{Al}$ Maylih and on the north side of Jabal Timiyah are also interpreted to have formed as parts of the Lughfiyah-Shuhban system. The dip of the L4 fault is unknown due to poor outcrop but is inferred to be shallow based on its curved western trace and the character of associated magnetic anomalies. Cross-section D-D' (fig. 8․ D) was constructed on this assumption and illustrates the probable joining of L4 with the Lughfiyah fault at depth to the south, analogous to the interpreted Lughfiyah-Shuhban relationship (fig. $8 \mathrm{~F}$ ). The minor chevron folds in the Jurdhawiyah group beneath the L4 fault (fig. 8D; pl. 1) and equivalent folds beneath the Lughfiyah fault at Jabal Timiyah (fig. 8무 pl. 1) are interpreted to represent contemporaneous deformation 
beneath these reverse faults. They are consistent with this interpretation because fold axes are parallel to fault traces, fold amplitude diminishes away from the faults, the sense of bending is compatible with reverse slip on the faults, and because folds of this scale and plunge within the Jurdhawiyah group are unique to the zone immediately beneath these faults.

\section{Rumah fault system}

The northwest-trending fractures of the Rumah fault system are entirely covered by alluvial and terrace gravel deposits of Wadi ar Rumah. The existence of these faults, however, is based on the disparities in structural and stratigraphic levels in the Ata-Shara block east and west of Wadi ar Rumah, on the apparent offset of the Ata fault trace, and on the mismatch of the Jurdhawiyah group east and west of the fault.

Correlation between the trace of Rumah fault segments and magnetic data is variable. Northwest of Uqlat as Suqur town, the fault coincides with a deep magnetic trough that is offset along the extension of the Al fault (fig. 8 $\mathrm{A}$ ); the trough is very weakly defined near Dhawqan, but is re-established west of the quadrangle (fig. 3; ARGAS, 1967; Cole, this report). Southeast of Uqlat as Suqur town, the Rumah fault appears to be offset along the A3 fault (fig. 8A), but the associated magnetic trough disappears south of its junction with the Ata fault. From this point southeast to the quadrangle boundary, the approximate trace of the Rumah fault is based on a subtle gradient, west of which the magnetic anomalies associated with the Dhiran-Suwaj terrane are more subdued and diffuse, although the northeast trend of the magnetic grain is continuous. The fact that this segment of the Rumah fault does not correspond with a magnetic lineament may indicate that the top of the (magnetic) Dhiran-Suwaj terrane is shallow west of the fault, or that the fault is a distributed zone of cataclasis rather than a discrete break.

The displacement on this segment of the Rumah fault (southeast of Uqlat as Suqur town) is chiefly down-to-the-west based on the absence of Dhiran-Suwaj outcrops and the greater thickness of the Jurdhawiyah group west of the fault. The amount of this displacement depends on the shape of the base of the Timiriyat conglomerate and its vertical extent west of the fault, both of which are unknown. However, the continuity of the Dhiran-Suwaj magnetic fabric across the fault suggests the vertical extent of the Timiriyat is not great, and an arbitrary several kilometers thickness were assumed in constructing the cross-sections (fig. $8 \underline{A}, \underline{H}, \underline{I}$ ). The down-to-the-west displacement is inferred to have occurred on this part of the Rumah trace during two phases that coincide with those of the Ata-Shara fault system. It was probably active during Timiriyat deposition as the eastern boundary of the graben, and was re-activated during uplift of the Ata-Shara block.

The second phase of movement on the Rumah fault requires a component of rotational slip to account for the apparent offset of the north-dipping Ata fault. Of several geometric possibilities, the preferred interpretation of this slip is that the south side of the Ata-Shara block west of the Rumah fault rotated down-to-the-south in absolute terms. This model is compatible with the unusually steep dips in the Jurdhawiyah group west of the Rumah fault and south of the Ata-Shara block, with the stratigraphic of fset of the Jurdhawiyah, and with the asymmetry of the schistosity arch in the Ata-Shara block (the crest of the arch is nearer the Shara fault, and north-dipping schistosity is more common; fig. 7). 
Displacements on the Rumah fault segments northwest of Uqlat as Suqur town cannot be accurately defined. The absence of Timiriyat conglomerate north of these fault segments suggests that displacement was down-to-the-north, but the possibility of an older graben structure that controlled Timiriyat deposition south of the (later) Rumah fault allows consideration of the opposite view. The Rumah fault system may have been active during Jurdhawiyah deposition in the Shuqrah basin because several strands broadly coincide with the basin margins (fig. 3). Post-Jurdhawiyah offset is also inferred. in that area from the apparent displacement of the basin axis across Wadi ar Rumah.

\section{STRUCTURAL EVOLUTION}

The wide variety of structures displayed by the rocks of this quadrangle record a complicated structural evolution related to diverse stress fields and thermal-mechanical conditions. Four principal structural events are recognized in this area, and the end of each is defined by a regional unconformity. These events are: 1) deformation and metamorphism of the Dhiran-Suwaj terrane prior to Murdama deposition; 2) regional folding of the Murdama group prior to Jurdhawiyah deposition; 3 ) opening and closing of the Idayri basin, northward-directed displacement on the Lughfiyah-Shuhban reverse-fault system, metamorphism and rise of the Ata-Shara block, and intrusion of Sodic microsyenite during late Jurdhawiyah deposition; and 4) regional extension following deposition of the Humaliyah formation, during intrusion of Sanidine porphyry dikes, and prior to Early Cambrian deposition of the Saq Sandstone.

Little primary evidence remains in this quadrangle related to pre-Murdama deformation because the Dhiran-Suwaj terrane is only exposed in the Ata-Shara block where it was further deformed at a later time, and because the Dhiran meta-andesite is a competent unit that does not record much deformation. However, the Dhiran was regionally metamorphosed prior to Murdama deposition, and the distribution of the Sodic metadacite member suggests regional folding or dismembered bedding. In adjoining areas beyond the influence of younger deformation in the Ata-Shara block, the Dhiran contains substantial biotite-hornblende schist whose planar fabric is generally parallel to pervasive cataclastic fluxion structure in some units of the Suwaj suite and parallel to the eastern extension of the Ata fault (Cole, 1984c, is prese).

In the interpretation of this report, this regional structural-metamorphic event recorded in the Dhiran-Suwaj terrane probably coincided with the formation of the Ata fault and produced the uplift that triggered deposition of the Murdama group. The Ata and Shara faults (and possibly the Rumah fault southeast of Uqlat as Suqur) appear to have been active during Murdama deposition because they bound the major uplifted block of Dhiran-Suwaj terrane and define a probable graben that received most of the Timiriyat conglomerate in the Mahalani basin (fig. 3).

A precursor fault (or flexure) in the approximate position of the Lughfiyah-Shuhban system may have also been active as the structural margin of the Jarir (Murdama) depositional basin, although it was probably less active than the Ata and Shara faults because conglomerate is rare at the base of the Jarir basin (Cole, $1984 \mathrm{c}, \mathrm{p}_{\mathrm{piex}}$. The lowermost unit of the Murdama at this locality is well bedded, sandy limestone that locally contains oolites, sparse relict shards, and volcanic plagioclase that indicate it was deposited in a shallow-water marine environment. The great thickness of limestone implies the Jarir basin continued to subside, but the uniformity of the limestone indicates deposition kept pace with flexing of the basin margin. 
Limestone in other parts of the quadrangle is similar, locally contains stromatolite fossils, and is interpreted to be the basal or near-basal unit that formed along the more stable margins of Murdama basins. The region of the Bakrah arch (fig. 3), for example, contains abundant limestone beds in the Sandstone unit, and thick-bedded limestone crops out near Jibal Qitan. By implication, sediments were deposited in shallow water over the Bakrah arch, and this arch probably remained structurally high throughout Murdama deposition. The conclusion is that the Bakrah arch represents a structural ridge of pre-Murdama "basement", and it may have shed debris to the flanking Mahalani and Maraghan basins before it was finally buried by shallow-water limestone and sandstone.

The second major structural event of the region is defined by regional folding of the Murdama group. Multi-kilometer-scale folds (fig. 3) are broad, open flexures that dominantly trend north-south in the Mahalani, Maraghan, and central Jarir (Cole, impreen) basins. Near basin margins and over the Bakrah arch, kilometer- and outcrop-scale folds are more common and are typically disharmonic. The style of these smaller folds throughout the Murdama suggests the unit lacked mechanical coherence, and are similar to structures formed during soft-sediment deformation. Further, no fold of any scale in the Murdama contains an axial-planar schistosity, even though large strains are recorded. All of these features indicate that the Murdama was probably folded during the final stages of deposition while the basin-fill was saturated with water.

Deformation during this event does not appear to have affected the Dhiran-Suwaj terrane. The fact that disharmonic folds are more common near the base of the Murdama (at the margins of depositional basins) suggests the Dhiran-Suwaj terrane behaved rigidly relative to wet Murdama sediments, and that the greatest folding strain was localized at this mechanical interface. Thus, the irregular folds in the area of the Bakrah arch (fig. 3; pl. 1) are interpreted as additional evidence that the base of the Murdama is shallow there.

The third major structural event of the region began with initial Jurdhawiyah deposition above a regional unconformity, and it was during this event that most of the major structures of the Uqlat as Suqur quadrangle were formed. The early phase of this event was characterized by regional extension and subsidence, and the linear Jurdhawiyah basins largely formed along the trends of pre-existing structures.

The Idayri basin (fig. 3) exemplifies the effect of structural inheritance. Its northern margin coincides with the down-to-the-south Shara fault, which had previously controlled the deposition of Timiriyat conglomerate during Murdama time as a down-to-the-north graben-bounding fault. Similarly, the southern margin of the Idayri basin largely coincides with the northern margin of the Jarir (Murdama) depositional basin; the probable fault that defined the basin margins must have also reversed its slip direction from Murdama to Jurdhawiyah time. This structural boundary (whether or not it was a fault) probably was a precursor to the present Lughfiyah-Shuhban fault system.

The Dhiran-Suwaj terrane in the eastern part of the Ata-Shara block, which was structurally high throughout Murdama sedimentation, probably remained high during Jurdhawiyah time, and locally provided coarse clastic debris to the Polymict conglomerate member. Approximately $10 \mathrm{~km}$ east of this quadrangle, the Idayri basin closes of $f$ and is bounded to the east by a large block of Dhiran-Suwaj terrane that was structurally high during Murdama and Jurdhawiyah time; its magnetic fabric implies the presence of west-trending faults that coincide with the trends of the Idayri basin (Cole, 1984c, in preac). 
The andesitic volcanoes that generated the Jurdhawiyah flow rock and volcaniclastic debris in the Idayri basin are inferred to have formed above conduits that are exposed today as dikes and plugs of the Plagioclase porphyry unit. Although most of the postulated volcanic centers for the Idayri basin lie east of this quadrangle, most are clustered near the basin margins (Cole 1984c, pawkthis report). This distribution pattern indicates the andesite magmas were probably channeled into conduits that were localized on the basin-bounding structures.

The distribution of Jurdhawiyah rock types in the Idayri basin records its history of subsidence and basin-margin uplift. The great thickness of coarse, thick-bedded Volcaniclastic conglomerate exposed along the southern basin margin requires that the rate of subsidence there was high and sustained, and that local andesite-volcanic sources were numerous. The northern basin margin is characterized by well bedded Volcaniclastic sandstone and probably subsided at a slower rate. The slight angular unconformity within this unit between Dawbah and Al Ifayhid probably reflects sporadic activity on the Shara fault during sedimentation.

The structural control and depositional history of the Shuqrah basin is not as clear because only part of it was studied for this project. The basin appears to be bounded by northwest-trending faults, and the southernmost of these is interpreted as part of the Rumah fault system (fig. 3). The Jurdhawiyah deposits of the Shuqrah basin do not extend north of the Raha fault zone, nor do the Murdama sediments of the Mahalani basin (fig. 1; Cole, this report; Williams, 1983; Williams and Simonds, 1985), but the relationship between the Raha fault and depositional basins is still unknown.

The structural history of most Jurdhawiyah basins involves no contemporaneous deformation other than faulting at the actively subsiding basin margins (Cole, 1981, 1984c, prew this report). However, the Idayri basin is unique in that its depositional history overlapped with northward-directed compression. This deformation produced the Lughfiyah-Shuhban reverse fault system along the southern basin margin, gently folded the Jurdhawiyah within the basin, and initiated the uplift of the Ata-Shara block along the northern basin margin.

The anomalous east-west trend of some folds in the Murdama are also attributed to this period of northward-directed compression. This conclusion is supported by the following observations: 1) east-west Murdama folds are unique to the margins of the Idayri basin (fig. 3; Delfour, 1977; Cole, 1981, prnes ; Young, 1982); 2) dome-and-basin interference folds in the Al Jimariyah area indicate superimposed west- and northnortheast-trending folds; 3 ) post-Murdama Plagioclase porphyry dikes have been pulled apart into boudins in the hinge-zone of west-plunging Murdama synclines (east of Al Habla and in the northern Jarir basin; fig. 8e; pl. 1; Cole, irnesw); and 4) the syncline east of Al Habla has irregular limbs that may reflect prior north-trending folds.

The effects of northward-directed compression within the Idayri basin proper are indicated by broad, chevron folds in the Jurdhawiyah group (pre-Shara conglomerate). The abundance of Volcaniclastic conglomerate on the southern side of the basin may also reflect basin-margin uplift related to early stages of this compression. The most pronounced effect, however, was establishment of the listric reverse faults of the Lughfiyah-Shuhban system that may have originated from the pre-existing structural boundary of the Jarir and Idayri basins. These faults displaced the Murdama several kilometers up and over the Jurdhawiyah group and, as they moved northward, locally overturned the Jurdhawiyah and formed minor chevron folds in the footwall blocks (near Al Maylih and at Jabal Timiyah). The Murdama (and, locally, Jurdhawiyah) above the reverse faults was folded and fractured by numerous subsidiary faults in response to crowding and continued northward displacement. The down-to-the-west 
rotational component deduced from several small, fault-bounded blocks in the Jibal ash Shuhban area may indicate that the Lughfiyah and Shuhban faults east of their junction slipped at a greater rate (or for a more extended period of time) than they did to the west.

The re-activation of the Ata and Shara faults and the deformation and metamorphism of the rocks in the Ata-Shara block are interpreted to be broadly contemporaneous with movement on the Lughfiyah-Shuhban fault system because these features are also contemporaneous with Jurdhawiyah sedimentation. Volcaniclastic sandstone on the north side of the Idayri basin contains clasts of schistose and nonschistose Murdama sandstone and notable amounts of detrital quartz, all of which are rare in the formation at other localities. These observations indicate the Ata-Shara block was structurally high, and contributed some debris to the northern Idayri basin in response to sporadic uplift on the Shara fault (and probably the Ata fault, as well).

The Shara conglomerate records a rapid phase of uplift of the Ata-Shara block, late during the depositional history of the Idayri basin. The Shara was deposited rapidly and chaotically in a non-marine environment on top of older, slightly tilted, subaqueous Jurdhawiyah sediments. The abundance of deformed clasts in the Shara indicates that uplift was rapid and that erosion had stripped the Ata-Shara block to the stratigraphic level of the Timiriyat conglomerate. The subhorizontal schistosity and rock fabric that characterize the block imply that horizontal flattening was the dominant strain, and the fact that schistosity merges with the bounding Ata and Shara faults indicates these features are genetically related.

Uplift of the Ata-Shara block on its bounding faults probably produced the schistosity by preferrential flattening of incompetent materials (Dhiran sodic metadacite, Timiriyat conglomerate, and Murdama sandstone) against Murdama overburden. The consistent north-northeast- and south-southwest-trending lineations in the block (fig. 7) suggest that this overburden was displaced of the rising uplif $t$ in those directions. This displacement, however, does not appear to have occurred on a discrete surface (decollement), but rather was distributed throughout the zone in which schistosity formed.

Preservation of the Shara conglomerate south of the central part of the Ata-Shara block, which contains the most intensely flattened and elongated rocks, is probably not coincidental. This central zone (approximately between Wadi ar Rijal and Jidhayib Marran) is also the center of the schistosity arch (fig. 3), which implies that uplift was greater than it was to the west or east. A reasonable interpretation is that the Shara conglomerate was thickest (and thus preserved) where uplift and erosion of the Ata-Shara block were greatest. The fact that the Shara is only exposed south of the block implies that uplift was asymmetric, and that the rate of slip was greater on the Ata fault than it was on the Shara fault. The asymmetry in slip between the two faults was probably compensated by rotational slip on the Rumah fault southeast of Uqlat as Suqur, as described above.

Although vertical compression was dominant during uplift of the Ata-Shara block, the deformation is inferred to have taken place within a regional stress regime of northward-directed compression (as with the contemporaneous Lughfiyah-Shuhban fault system). The dominant east-west Murdama folds in the Al Jimariyah area were re-oriented from older folds by this stress system. The folds pre-date schistosity (fig. 7), as do felsic dikes (Deformed and altered dike-rock unit) and beds of Murdama Felsophyre member, but these competent materials contain abundant, post-schistosity, dilational quartz veins that have a preferred north-northwest trend, which is consistent 
with northward-directed compression. The geometry of the Sal fault (fig. $8 \underline{A}, \underline{H}$ ) also requires northward-directed compression during or following formation of schistosity, at least locally within the block.

An apparent contradiction arises with regard to the pattern of uplift deduced for the Ata-Shara block. If the center of the schistosity arch defines the zone of greatest uplift as the area between Wadi ar Rijal and Jidhayib Marran, then it seems inconsistent that sub-Murdama Dhiran-Suwaj terrane is not exposed there, but rather on the east side of the Rumah fault where uplift was less. Therefore, it seems likely that the Dhiran-Suwaj terrane east of the Rumah fault was structurally high throughout Murdama and Jurdhawiyah time (it provided cobbles to both units), due to recurrent movement on the Ata and Rumah faults. It is not exposed where uplift was greatest in the central part of the Ata-Shara block because the late-Jurdhawiyah slip on the Rumah fault was less than the (deformed) thickness of the Timiriyat conglomerate.

The cause of uplift and related deformation of the Ata-Shara block is enigmatic. The uplift is contemporaneous with the northward-directed compressional stresses that formed all of the major structures in the southern part of the quadrangle, and yet scarcely a trace of this strain is present north of the Ata fault, which must have absorbed that stress by additional displacement. The fault has clearly had a complex history of repeated slip (in various directions), it contains serpentinite, cataclastic breccia, and listwanite, and it is probably a major crustal-structural boundary that divides the Dhiran-Suwaj terrane. This "basement" beneath the Murdama in the Mahalani basin must have acted as a rigid buttress, whereas the Ata-Shara block (previously downdropped in a graben during Murdama time) was forced upward on its bounding faults. The very gentle warping of the Jurdhawiyah deposits in the Idayri basin implies that they too must rest on a relatively rigid block of Dhiran-Suwaj terrane. Thus, the uplift of the Ata-Shara block suggests that it was extruded upward by the northward displacement of a rigid block (carrying the Idayri basin) against a similarly rigid block (carrying the Mahalani basin).

The irregular plugs and dikes of the Sodic microsyenite unit are attributed to approximately the same period as the northward-directed compression because they are chiefly confined to the region deformed at that time. Sodic microsyenite intrudes both the Shara fault and the Shara conglomerate and therefore appears to postdate the major uplift of the Ata-Shara block. However, it is notable that these plugs were generally intruded above the south-dipping Lughfiyah, Shuhban, and Shara faults. The peculiar composition of the Sodic microsyenite ( 80 percent oligoclase) is similar to the eutectic composition of low-potassium, mafic materials (Morse, 1980), and may have originated by limited partial melting of Dhiran-Suwaj or Murdama rocks. Cross-section I-I' (fig. 8I) illustrates a possible interpretation that Sodic microsyenite formed along these fault zones by partial melting. The fact that these plugs intrude the Shara fault and the Shara conglomerate may only reflect an expectable time lag between frictional heating and emplacement of this viscous magma. The distribution of Sodic microsyenite plugs in a linear array from Jabal ash Shabah northeast to Al Ifayhid and the Shara fault implies a structural control, and may indicate the Shara fault flattens at depth and joins(?) the Lughfiyah-Shuhban system.

Intrusions of the Idah suite are simple elliptical to circular plutons of nonfoliated rock that clearly truncate fractures and folds related to the I ughfiyah-Shuhban fault system. Several lines of evidence, however, imply that the Idah suite may have overlapped or closely followed the compressional deformation that marks the end of the third major structural event. First, the distinctly older Granodiorite unit of the Idah is faulted in the vicinity of Shaib Mutribah and farther south (Cole, in prend). Second, the 
Idah is absent in the zone of greatest compression even though Idah plutons are common throughout the region. Third, the bulk composition and compositional range of the Idah suite and the volcanic rocks of the Jurdhawiyah group are very similar (Cole, $1982,1984 \mathrm{~b}$ ), and they are inferred to be genetically (and, therefore, temporally) related. Nevertheless, emplacement of the bulk of the Idah suite in simple cylindrical bodies suggests regional stresses had diminished, and the Idah was succeeded by about $30 \mathrm{Ma}$ of structural quiescence, erosion, and planation.

The fourth identifiable structural event in this part of the Shield is interpreted to be broadly contemporaneous with the Humaliyah formation, the Qitan complex, and the Sanidine porphyry unit. The event is represented by subparallel, down-to-the-south normal faults in the west-central part of the quadrangle that of set the Humaliyah formation. These structures imply regional extension in a northwest-southeast direction, and the consistent, parallel trend of the regional swarm of Sanidine porphyry dikes is also consistent with this stress field.

Some pre-existing faults were re-activated during the fourth event (Shara fault

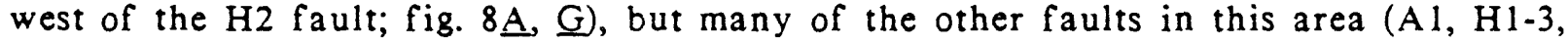
$\mathrm{J} 1$, and $\mathrm{J} 3$ ) may have initially formed at this time (evidence for prior displacement is not definitive). Total displacements on these fractures appears to be less than a few hundred meters.

The inferred time of this event is latest Proterozoic, but there is no evidence that any of the deformation overlapped with Early Cambrian deposition of the Saq Sandstone. Its limited outcrop at Jabal Timiyah only demonstrates that it post-dates movement on the Lughfiyah-Shuhban fault system. 


\section{ECONOMIC GEOLOGY}

The ancient workings at An Najadi and in the Al Habla-Al Madraba area are two of the most extensively mined sites in the northeastern Shield, and gold was the principal commodity extracted. The geologic setting of the two areas is similar and forms the basis for recognizing equivalent environments in other parts of the northeastern Shield, and the Uqlat as Suqur quadrangle contains several prospective zones. Polymetallic mineralization (silver, gold, and some base metals) at Al Habla East was deposited in the Shuhban fault, and the geologic framework described in this report provides a model for exploration of other parts of the Lughfiyah-Shuhban fault system.

Contact-metamorphosed limestone of the Murdama group is exposed in two areas of the quadrangle adjacent to intrusions of the Idah suite and the Qitan complex. Although no overt signs of mineralization have been detected, the geologic setting is prospective and is described in this section. Similarly, quartz-tourmaline veins near Jibal al Khusayyayn are described, although their mineral potential is unknown.

\section{GOLD ASSOCIATED WITH THE IDAH SUITE}

Veins in the extensive ancient workings at An Najadi (MODS 1272), in the Al Habla area (MODS 1267, 1286, and 3512), and at Al Madraba (MODS 3513) contain gold in the free state and minor sulfide minerals, and were formed during emplacement of the Idah suite $(620 \mathrm{Ma}$ to $615 \mathrm{Ma}$ ago; Cole and Hedge, unpublished data). These vein systems are located within some of the Idah-suite plutons, although they are more common in adjacent hornfelsed Murdama sandstone. The vein character and geologic setting in these three areas are directly comparable to those in the Sukhaybarat district (MODS 405, 406) a short distance to the southwest, where potentially economic mineralization is being explored under concession to Granges-Boliden at the time of this report.

Al Habla (MODS 1286), near the south-central border of the Uqlat as Suqur quadrangle, has been known for many years and was briefly studied and reported by Fakhry (1941), Dirom (1946), Schaffner (1955a, b, 1956), Mytton (1970), Begg (1980), and Colliver and Woollett (1981). Most of these reports are based on surface examination and sampling, but Schaffner (1955b) excavated the ancient workings to a depth of several meters. He recommended sites for nine drill holes (Schaffner, 1955a), but the work was never initiated.

An improved understanding of the geologic setting and significance of the Al Habla mineralization (Cole, 1984a), which was based on this reconnaissance mapping, lead to a new program of study by the USGS in 1982 and 1983. Prospectors discovered three additional zones of ancient workings that were recorded as the Al Habla South-central site (MODS 1267), the Al Habla Southeast site (MODS 3512), and the Al Madraba site (MODS 3513). These three zones have an aggregate worked-length of about $2 \mathrm{~km}$, whereas the trenches at the central Al Habla site are traceable for almost $4 \mathrm{~km}$ along a northerly trend. All workings in the district were investigated by Smith and others (1984a) by trench excavation, detailed mapping, and systematic sampling, and the following description is based on their report and that of Cole (1984a). 
The mineralized veins at Al Habla (central workings, South-central, and Southeast) are chiefly within leucocratic biotite syenogranite porphyry (Granite unit, Idah suite), and are locally parallel to cogenetic aplite dikes. Veins are generally steep and trend toward the north in the western lobe of the pluton and in the central workings; the veins in the Southeast workings trend slightly east of north and seem to generally dip westward toward the pluton center (Smith and others, 1984a). The South-central workings follow shorter veins in the syenogranite porphyry and in Murdama sandstone that trend in a northwesterly direction parallel to the contact.

The Al Madraba workings are in a separate intrusion several kilometers southeast of Al Habla that consists of Idah-suite granodiorite porphyry. The veins are generally steep and most follow the westerly trend of cogenetic aplite dikes, although a few shorter veins trend northerly, parallel to abundant diabase dikes. Minor quartz veins in Murdama sandstone have been worked near the northern contact of the granodiorite porphyry. The ruins of small ancient villages at both Al Madraba and the central Al Habla workings contain common grindstones, hand tools, and fragments of glass and pottery.

All veins in the Al Habla-Al Madraba district are similar and consist of medium- to coarse-grained quartz with minor pyrite and local chalcopyrite and galena. Trench excavations show that the quartz forms thick, tabular veins (10 to $100 \mathrm{~cm}$ thick) and local veinlet stockworks in the marginal aplite dikes. Hydrothermal alteration is sparse, except in the South-central workings and locally at Al Madraba, where silica, epidote, and some potassium feldspar appear to have been introduced. The outer rim zone of the Al Habla granite pluton is oxidized, contains some sericitic alteration, and locally contains coarse pyrite (Cole, 1984a), but no connection is apparent with the mineralized veins.

Dump samples and trench samples, collected along $10-\mathrm{m}$ intervals in all of the workings; contain maximum values of $35 \mathrm{ppm}$ gold and $15 \mathrm{ppm}$ silver in discontinuous, rich pockets. The estimated average grade of the dump material is approximately 8 ppm gold and 2 to $4 \mathrm{ppm}$ silver (Smith and others, 1984a), and the mined ore was probably twice as rich. Lead, copper, and local high values of tungsten and molybdenum are associated with all sample materials, but not in recoverable amounts.

The geologic setting at An Najadi (MODS 1272) is similar to that at Al Habla-Al Madraba, except that the intrusive rock is a small plug of Idah-suite diorite, and most of the mined veins are in hornfelsed calcareous Murdama sandstone (Cole, this report). More than 40 trenches were mapped along north-northwest-trending quartz veins by Fakhry (1941), and additional veins are exposed in an area of about $5 \mathrm{~km}^{2}$, chiefly east and south of the diorite plug (Smith and others, 1984b). About half of the workings are north of lat $26^{\circ} 00^{\prime} \mathrm{N}$. in the adjoining quadrangle (Williams, 1983), but the following description is based on the entire locality (Cole, this report; Smith and others, 1984b).

An Najadi contains the ruins of numerous building foundations, grindstones, ore-sorting piles, hand tools, and other artifacts that indicate a large community worked the deposit over an extended period. Some of the ore in stockpiles is dissimilar to the material exposed in ancient trenches (it contains abundant galena or copper sulfides) and may have been imported to An Najadi for smelting, as indicated by minor amounts of slag at the site. 
Schaffner (1956) excavated some of the ancient workings to a depth of about $13 \mathrm{~m}$, but did not reach the bottom of the worked zone. Detailed mapping and systematic sampling were completed in 1983 by Smith and others (1984b). The character and mineralogy of the veins is similar to those at Al Habla, although sulfide minerals are sparse. The extent of ancient workings suggests the deposit was rich and worked for a prolonged period, but analysis of dump and quartz-vein samples characteristically produce low values for gold and silver (less than 5 ppm total), and base metals (Schaffner, 1956; Smith and others, 1984b). The reasons for this discrepency are presently unknown, although it appears that the exploitation of An Najadi was atypically thorough (Smith and others, 1984b).

The similar geologic controls to the mineralization at Al Habla-Al Madraba and at An Najadi have also been recognized at other gold deposits in large parts of the northeastern Shield (Kleinkopf and Cole, 1982; Boyle and Howes, 1983; Cole, 1984a). The intrusive rocks that appear to be uniquely associated with this type of mineralization are those defined in this report as the younger units of the Idah suite (Diorite, Granodiorite porphyry, and Granite) that typically intrude as circular-toelliptical plutons. The size of the intrusion does not appear to be a critical factor because An Najadi (and many of these deposits) formed around a small plug, but two of the better prospects (Al Habla and Sukhaybarat) are associated with larger intrusions.

Prospective environments for this type of mineralization in the Uqlat as Suqur quadrangle include the Idah-suite diorite body south of Jabal Akkash and the numerous plugs and plutons of Diorite and Granodiorite porphyry that intrude the Murdama in the Mahalani and Maraghan basins. East and northeast of this quadrangle, several small areas of ancient excavations are known from the Maraghan basin, and most are near small plugs of rock correlated with the Idah suite (du Bray, inprof; Cole, 1984c).

Minor ancient workings and sparse quartz veins were recently discovered at the Jabal Akkash site by Boyle and Howes (1983; MODS 3114, renamed Jabal Akkash from the original designation as "Sukhaybarat Northeast"). Sparse, unworked quartz-veins are exposed in the small plug of Idah-suite diorite $5 \mathrm{~km}$ east of At Tarfawi. The northern of two Granodiorite porphyry plugs $7 \mathrm{~km}$ northeast of At Tarfawi contains more widespread veins (also unworked) and disseminated pyrite in wall-rocks, in the plug, and in aplitic dikes. Some quartz veins have textures that indicate multiple stages of filling and minor brecciation (Cole, this report).

\section{POLYMETALLIC DEPOSITS, SKARNS, AND MISCELLANY}

Mineralization at the Al Habla East occurrence (MODS 1287) is localized at the intersection of the Shuhban fault with subsidiary faults, and contains some gold and silver in sulfide-rich lenses within the fault zone. Previous study by Mytton (1970) was based on surface examination, but more definitive work was completed in 1983 (Smith and others, 1984a; Cole, 1984a) and included trench excavation and systematic sampling.

The ancient workings at Al Habla East are discontinuous along the fault zone, but cover a distance of more than several hundred meters. Veins in the fault zone consist chiefly of quartz (locally brecciated and cataclastic), hematite, and calcite, with minor amounts of pyrite, sphalerite, and galena. Smith and others (1984a) report that trench and surface samples generally contain about $3 \mathrm{ppm}$ gold and less than one ppm silver; local high values of arsenic, zinc, lead, and copper are typical but none is present in 
extractable amounts. No other mineralization of this type is known in the area, but the apparent control by the Lughfiyah-Shuhban fault system (and perhaps by Murdama limestone in the hanging-wall block) provides a basis for further prospecting in the southern part of the quadrangle.

Recrystallized limestone and skarn minerals are known from two localities in the Uqlat as Suqur quadrangle. The folded limestone on the southeast flank of the Qitan complex and northwest of the Idah-suite intrusion at Al Khullah locally contains a calc-silicate mineral assemblage consisting of coarse epidote, andesine, sphene, scapolite(?), and minor garnet, particularly within a few hundred meters of the Qitan complex and near dikes of the Granite porphyry member. North of Jabal Idah on the margin of a large Idah-suite Granodiorite porphyry pluton, Murdama limestone is white or dark blue and thoroughly recrystallized, but appears to have been too pure to form calc-silicate minerals. Sulfide minerals have not been located at either locality and rock samples contain no anomalous metal values (Cole, 1984b).

Both of these sites have only been reconnoitered, and colluvium and eolian sand cover the contacts between limestone and the intrusive rocks. They are believed to have mineral potential on the basis of geologic setting, and because scheelite and powellite have been discovered in the same setting (Murdama limestone near Idah-suite granodiorite porphyry) $80 \mathrm{~km}$ southeast of this quadrangle (Johnson, 1983b).

Approximately 5 thick quartz-tourmaline veins form a discrete swarm that is distinguished on the basis of mineralogy and trend from the common and widespread barren quartz-chlorite-calcite-hematite veins in the Ata-Shara block. These veins are located about $2 \mathrm{~km}$ northeast of Jibal al Khusayyayn in Dhiran meta-andesite and trend toward the north-northeast, whereas other veins typically trend northwesterly in this area. The tourmaline-bearing veins are 30 to $50 \mathrm{~cm}$ thick and have a distinctive sugary texture and lavender color. In addition to quartz and abundant olive-green to pale-brown tourmaline, these veins contain primary fluorite, primary calcite, and anatase. Samples contain large amounts of boron and sporadic, maximum values of 200 ppm molybdenum, but background amounts of most other elements (C. W. Smith, written commun., 1984). 


\section{SUMMARY AND REGIONAL IMPLICATIONS}

The geology of the Uqlat as Suqur quadrangle is interpreted to record the formation of new, primitive, continental crust in this part of the northeastern Arabian Shield, and its subsequent maturation by repeated deformation and intrusion, that produced a stable, continental craton. This evolutionary process took place during a brief interval in the late Proterozoic (between about $700 \mathrm{Ma}$ and $570 \mathrm{Ma}$; Stuckless and others, 1984; Cole and Hedge, 1984, unpub. data), and distinguishes this area from large parts of the western and southern Shield that were formed prior to $700 \mathrm{Ma}$ (Cooper and others, 1979; Fleck and others, prin; Darbyshire and others, 1983; Stacey and Stoeser, 1983). Figure 9 illustrates the interpreted sequence of events for the region and the evolution of the geologic framework that marks the formation of the crust in this part of the Shield.

The interpretive model of Figure 9 has geographic limitations, because adjoining parts of the Shield record distinctly different evolutionary histories. The model is believed to be valid north and northeast of the Uqlat as Suqur quadrangle to the unconformable base of the Hibshi formation (fig. 1), which marks the northern limit of depositional basins for Murdama- and Jurdhawiyah-type rocks (Johnson and Williams, 1984; Quick and Doebrich, presw; Cole, this report). North of this base, the Hibshi rests on quartz diorite that is $650 \mathrm{Ma}$ old (Cole and Hedge, 1984, unpub. data) and no intrusive rocks of that age have been demonstrated in the region south of the unconformity (fig. 9). The applicability of the model is also limited to that part of the Shield northeast of the Halaban-Zarghat fault (fig. 1) because it is a major crustal boundary that has had a complex history (Cole, prew ) and because major rock units southwest of the fault are known or inferred to be older than $700 \mathrm{Ma}$ (Calvez and others, 1983; Stacey and Stoeser, 1983; Pellaton, 1984b).

Figure 9 includes estimates of the crustal volume-percentage represented by each of the major rock units in this part of the northeastern Shield, prior to deposition of the Saq Sandstone in the Cambrian Period. These estimates are based on structural projections and (to some degree) aeromagnetic data, and represent the inferred depth of sedimentary basins and the inferred vertical extent of intrusive masses. The derived volume figures are not rigorously defined, but probably reflect the approximate proportions of the various units in the upper $10 \mathrm{~km}$ of the crust.

The volume-percentage figures were estimated to emphasize the rate of growth of this part of the Shield crust, and to evaluate the contribution of various rock-forming episodes to that growth. The figures imply that the Dhiran-Suwaj terrane and its eroded debris (Murdama group) represent approximately half of the crust, and that most of the remaining half was added during a brief period of magma generation (about 640 to $615 \mathrm{Ma}$ ago) that produced the volcanic rocks of the Jurdhawiyah group and the voluminous intrusions of the Idah suite. The latest Proterozoic volcanicintrusive event, represented in this quadrangle by the Humaliyah formation and the Qitan complex (585 Ma to $575 \mathrm{Ma}$ old), probably only added about 10 percent new material to the Shield crust.

The oldest layered rocks of this quadrangle (Dhiran meta-andesite) and the oldest intrusive rocks (Suwaj suite) are similar to the oldest rocks in various parts of the Shield and are interpreted to have formed together, probably in an ensimatic subduction system (Cole, prim ; this report). The Dhiran and corresponding units in the region (fig. 2) consist of mafic metavolcanic rocks, minor but characteristic sodic metavolcanic rocks, and immature metasedimentary rocks, typically described as 


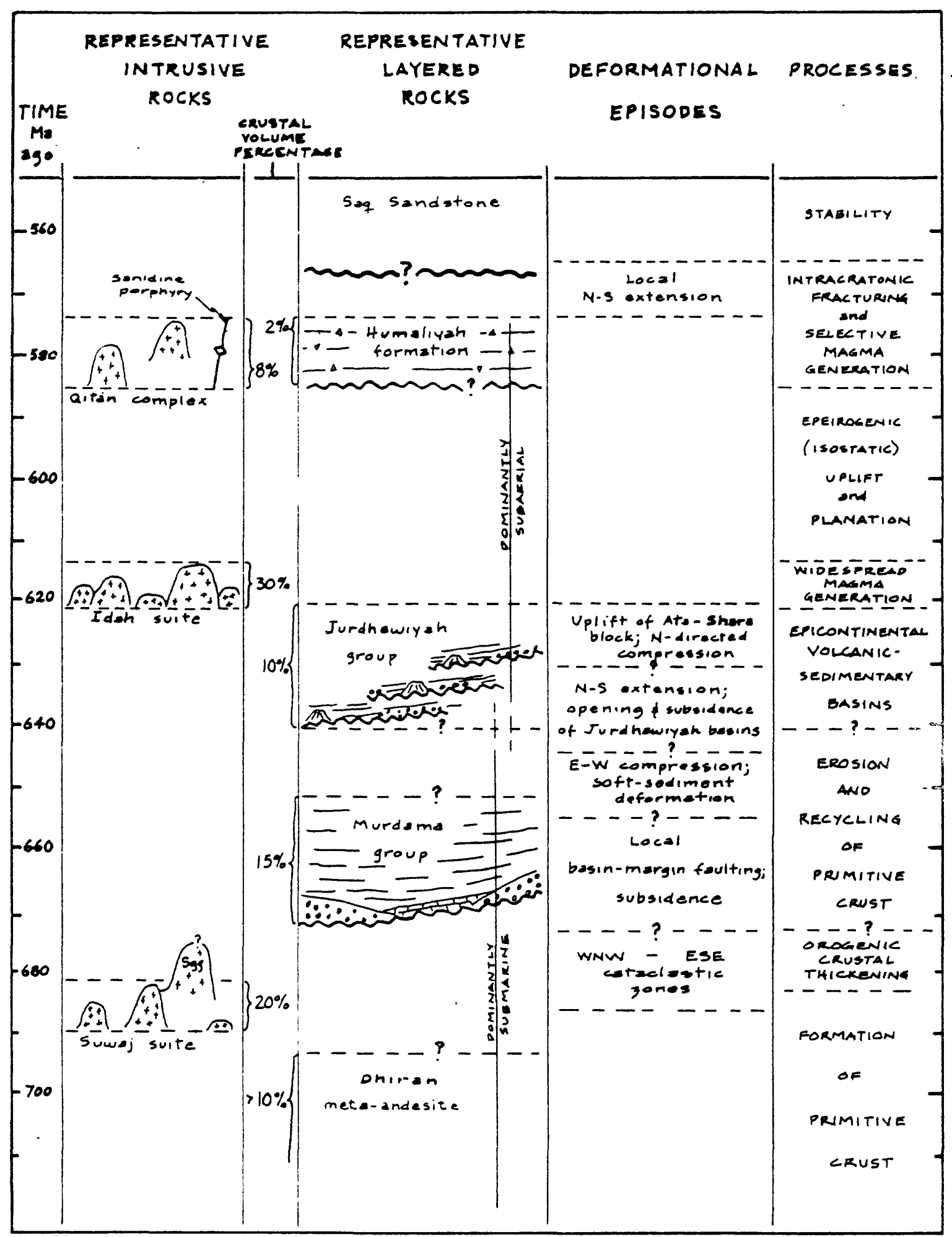

Figure 9.--Interpreted geologic evolution of rock units and structural events for the Uqlat as Suqur quadrangle and vicinity. Absolute time scale based on Stuckless and others (1984) and unpublished data by the author and $C$. E. Hedge. See text for geographic limitations on the applicability of this evolutionary sequence, and for explanation of "crustal volume percentage". 
volcanic sandstone or breccia, metagraywacke, biotite-hornblende schist, biotite paragneiss, and para-amphibolite (Delfour, 1977; Beurrier and Villey, 1982; Bohannon, 1984; Cole, 1984c, owne). The Suwaj suite regionally consists of mafic plutonic rocks (diorite, quartz diorite, tonalite) and low-potassium granodiorite whose overall composition and compositional range are similar to the volcanic rocks in the Dhiran and corresponding units (Cole, 1982, 1984b, in prew).

Zircon from three mafic units of the Suwaj in the region define overlapping emplacement ages in the narrow interval between about $690 \mathrm{Ma}$ and $680 \mathrm{Ma}$ (Cole and Hedge, 1984, unpub. data), but the minimum age of the suite may be somewhat lower because the younger Granodiorite granophyre unit has not been dated. In the interpretation of this report, these ages also apply to the whole of the Dhiran-Suwaj terrane, which is probably not much older than $700 \mathrm{Ma}$. This terrane is comparable to the volcanic-plutonic assemblage south of the Halaban-Zarghat fault that Stacey and others (1984) conclude formed in an ensimatic volcanic arc above subducting oceanic lithosphere. They infer the age of that lithosphere from the Urd gabbro $(695 \pm 9 \mathrm{Ma})$ and the minimum age of the volcanic arc from the As Sawda tonalite $(677 \pm 9 \mathrm{Ma})$, and thereby define the local formation of primitive (neo-continental) crust in the same interval as the Dhiran-Suwaj terrane.

In adjoining parts of the Shield, the oldest local volcanic-plutonic assemblages have also been interpreted to represent the formation of primitive crust in ensimatic or continent-marginal volcanic arcs (Schmidt and others, 1979; Roobol and others, 1983), but the time of crust formation is variable from arc to arc. For example, layered rocks correlated with the Halaban and Hulayfah groups in the central part of the Shield probably formed in several arcs that were active between about $760 \mathrm{Ma}$ and $715 \mathrm{Ma}$ (Stoeser and Camp, 1984). The Al Amar group in the easternmost part of the Shield, however, probably formed in an arc that was active between about $650 \mathrm{Ma}$ and $630 \mathrm{Ma}$ (Calvez and others, 1983; Stacey and others, 1984).

There is little direct information in this quadrangle relating to the deformation and metamorphism of the Dhiran-Suwaj terrane and the termination of its proposed subduction system. However, several workers have proposed that these three events were broadly coeval and are part of a widespread structural event in the eastern Shield, perhaps related to the collision of lithospheric plates (Schmidt and others, 1979; Jackson and Ramsay, 1980; Stacey and others, 1984; Stoeser and Camp, 1984). It was probably at this time that the precursor to the Ata fault began displacement in the Uqlat as Suqur quadrangle and, along its trend to the southeast, pervasive cataclastic foliation formed in some rocks of the Suwaj suite (Cole, 1984c, is press).

The scope and duration of this proposed structural event imply a significant orogenic episode, during which the volcanic-plutonic assemblages were substantially folded, variably metamorphosed, and (west and south of this area) intruded by foliated plutonic rocks (Schmidt and others, 1979; Stacey and others, 1984; Stoeser and Camp, 1984). These events had the effect of thickening the primitive crust and inducing its uplift and erosion (fig. 9).

The dominantly clastic rocks of the Murdama group are interpreted in this report to be the direct result of this major structural event, and thus were deposited above a regional unconformity during the orogenic uplift. Initial deposition of Murdama is inferred to have begun about $670 \mathrm{Ma}$ ago (fig. 9), which is consistent with the age of the Suwaj suite and the As Sawda tonalite (the youngest dated rocks beneath the unconformity). The evidence in this quadrangle clearly shows that essentially all of the debris in the Murdama was derived from the Dhiran-Suwaj terrane. 
Contemporaneous volcanic activity is largely ruled out for the Murdama in this part of the Shield on the basis of its clast composition (Cole, this report; Greene, 1983, 1984. daftale) although minor felsic volcanic activity is indicated by shards and relict feldspar phenocrysts contained in the Limestone unit, and by sparse ignimbrite at the base of the Murdama $60 \mathrm{~km}$ to the south (Pellaton, 1984a).

The distribution of Murdama depositional basins was probably controlled by faults that formed during the preceding structural event, and the Ata fault is interpreted to show this type of structural inheritance. Similar features may be demonstrable elsewhere, but possibly the strongest argument can be made from the regional distribution of the Murdama. Throughout the eastern Shield, deep basins of clastic rock correlated with the Murdama group are consistently aligned toward the northnorthwest (Johnson, 1983a) and are parallel to and east of the proposed axis of orogenic uplift of the deformed older terranes (Stoeser and Camp, 1984).

The Timiriyat conglomerate and the Limestone unit were deposited on the margins of the subsiding Murdama basins and the distribution of the two units probably reflects areas of active faulting and passive subsidence, respectively. These two lithologic units were characteristically deposited at the base of the Murdama across the eastern Shield (Greene, 1983, preis ; Johnson, 1983a), and thus are most certainly time-transgressive units. The overlying and dominant part of the Murdama everywhere consists of uniform, thinly bedded, feldspathic sandstone that is interpreted to have been deposited in the subsiding, but structurally quiescent, centers of the deep marine basins.

The regional folding and local, disharmonic crumpling of the Murdama coincided with the end of deposition (Cole, this report). The regional folds have a dominant northerly trend that is generally parallel to the trend of the original depositional basins. Thus, it is not possible to infer the orientation of the regional stress regime because compression in any direction roughly transverse to the depositional basins could have produced this fold pattern by "squeezing" the Murdama between rigid basinmarginal Dhiran-Suwaj blocks. Cole (in pnuy) suggests that this folding may have coincided with the major episode of transverse movement on the Halaban-Zarghat fault, which of fets the Murdama basins by as much as $65 \mathrm{~km}$.

The deformation of the Murdama was followed by volcanic activity that generated the deposits of the Jurdhawiyah group. The Jurdhawiyah is clearly distinguished from the Murdama because it represents the addition of new material to the crust, and it marks the beginning of the second major phase of crust formation. The time of initial Jurdhawiyah volcanic activity has not been determined, but has been estimated to precede the (postulated cogenetic) intrusive rocks of the Idah suite by about $20 \mathrm{Ma}$ (fig. 9). This age is also based on a direct date of $632 \pm 5 \mathrm{Ma}$ for dacitic volcanic rock in the upper part of the Hibshi formation of Williams (1983), which is interpreted to correspond to the Jurdhawiyah group (fig. 2; Cole and Hedge, 1984, unpub. data).

Evidence in this report indicates the Jurdhawiyah depositional basins formed during regional crustal extension, and that the basin margins in many cases were controlled by vertical displacements on pre-existing faults. The sites of volcanic sources for Jurdhawiyah deposits were largely guided by these zones of weakness (Cole, in prewi), and the basins rapidly filled with volcanic debris eroded from the contemporary volcanoes. The local abundance of welded, oxidized, pyroclastic rock and sedimentary structures in the region (rain-drop imprints; Cole, 1981, 1984c; Williams, 1983) indicate the Jurdhawiyah depositional environment was partly sub-aerial, although much of the Idayri basin in this quadrangle was shallow-water sub-aqueous. 
The distribution of rock types in the Jurdhawiyah basins (characterized by rapid lateral and vertical facies changes, and the presence of local intraformational unconformities) indicates rapid and sporadic subsidence, probably in response to variable regional extension. In contrast to Murdama basins, the margins of Jurdhawiyah basins were probably not substantially uplifted (in absolute terms) because the overwhelming bulk of Jurdhawiyah sediment came from contemporaneous volcanic centers, and extra-basinal debris (represented by the Polymict conglomerate member) is rare. Volcanic activity and sedimentation probably began at different times and lasted for different periods in the various basins. For example, dacitic and rhyodacitic Lapilli tuff form the lowermost unit in the Shuqrah basin, whereas similar material is only present in the upper Jurdhawiyah of the Idayri basin.

Most Jurdhawiyah basins are largely undeformed (Cole, 1981, in prew, but evidence from this quadrangle shows that the Idayri basin was substantially deformed late during its depositional history. The structures formed are attributed to a northwarddirected compressional stress system that: 1) re-oriented and interfered with prior Murdama folds in the Al Jimariyah area; 2) moved Murdama (Jarir basin) several kilometers up and over Jurdhawiyah along the Lughfiyah-Shuhban reverse fault system; 3) re-activated the Ata, Shara, and Rumah faults; 4) initiated the uplift of the Ata-Shara block, during which it was metamorphosed and intensely flattened; 5) triggered the rapid deposition of Shara conglomerate on the south side of the asymmetrically uplifted Ata-Shara block; and 6) coincided with the generation of minor partial melt (Sodic microsyenite unit), possibly by frictional heating along fault surfaces.

This deformation appears confined to the immediate vicinity of the Idayri basin because the stresses do not appear to have been transmitted north of the Ata fault. The Hibshi-formation basin was similarly folded and fractured by south-dipping reverse faults (Johnson and Williams, 1984) prior to emplacement of Idah-suite granodiorite $(621 \pm 5 \mathrm{Ma}$; Cole and Hedge, 1984, unpub. data), and that deformation does not extend south of the Raha fault zone (fig. 1). The similarities between the Raha fault zone (du Bray, pnesy): Williams, 1983) and the Ata fault are considerable, as noted by these features: 1) the Raha separates Murdama sandstone and limestone from polymict conglomerate (in the Qarnayn sandstone of du Bray, prese) that is very similar to the Timiriyat (fig. 2; Cole, this report); 2) this conglomerate is intensely flattened and locally schistose parallel to and beneath the Raha; 3 ) the Hibshi depositional basin is bounded by the Raha along much of the basin length (Williams, 1983), 4) the trace of the Raha fault zone contains discontinuous lenses of serpentinite, metagabbro, and listwänite (du Bray, 官rew, and 5) irregular dikes of material similar to the Sodic microsyenite unit of this report intrude the deformed rocks north of the Raha fault (Cole, this report; lat $26^{\circ} 22^{\prime}$ N., long $42^{\circ} 37^{\prime}$ E.).

The spatial relation of these features to the trace of the Raha fault zone is the mirror image of their counterparts along the Ata fault, and the mirror-symmetry is supported by minor structures along the trace that imply the Raha dips steeply to the south (Cole, this report). Thus, the deformation in the southern part of the Uqlat as Suqur quadrangle may be part of a regional event that deformed some Jurdhawiyah-age basins near other major crustal boundaries, but whose cause and significance is not yet understood.

The subsequent intrusion of Idah-suite magmas probably represents the single most significant contribution to the crust of this part of the Shield (fig. 9). The suite is characterized by calc-alkaline granodiorite and related diorite and syenogranite, similar in terms of bulk composition and compositional range to the volcanic rocks of the Jurdhawiyah group (fig. 5; Cole, 1982; 19846). Similar assemblages of intermediate 
to felsic calc-alkaline volcanic and intrusive rocks of this or greater magnitude (crustal volume-percentage) are characteristic of destructive margins of continental lithosphere plates (for example, in the Mesozoic and Cenozoic terranes of the circum-Pacific region; Gill, 1981). However, the distribution of Jurdhawiyah-type volcanic deposits and of Idah-type intrusive rocks does not form a linear array in the northeastern Shield (Cole, ixprears), and no contemporaneous destructive plate margin has been identified. The Jurdhawiyah-Idah assemblage may be more similar to the widespread but dispersed calc-alkaline intrusive and volcanic activity recorded in the Cretaceous and Lower Cenozoic of the southwestern United States (Snyder and others, 1976; Gill, 1981).

Emplacement of the Idah suite corresponds with the most widespread metallogenic event of the region, during which gold was deposited in quartz-vein systems. Recognition of the lithologic and chemical traits of the Idah, and of its style of intrusion and characteristic magnetic signature and contact metamorphism, form the basis for exploration guides in the region (Cole, 1984a, d, this report; Kleinkopf and Cole, 1982; Boyle and Howes, 1983). The Murdama basins are considered more prospective for this type of deposit because the Idah intrudes the Murdama more commonly than it does the Jurdhawiyah. For the same reason, Idah intrusions should be explored for tungsten and molybdenum where they intrude Murdama limestone.

Cessation of Idah intrusion also coincides with an interval of about $30 \mathrm{Ma}$ (between approximately $615 \mathrm{Ma}$ and $585 \mathrm{Ma}$ ) during which no layered or intrusive rocks are known to have formed. This hiatus is interpreted to reflect a period of isostatic uplift, erosion, and probable planation during which the Shield crust adjusted to its postIdah-suite density distribution. Evidence for planation at this time is inferred from the fact that Idah-suite rocks are very poorly exposed relative to the youngest Proterozoic intrusive rocks (Abanat suite of Cole, 1984c), even though these younger rocks are more intensely weathered at present (Cole, this report).

The youngest Proterozoic rocks of the region were formed during a brief period from about $585 \mathrm{Ma}$ to $570 \mathrm{Ma}$ (Stuckless and others, 1984) that was characterized by moderate regional extension in a north-northwesterly direction (Cole, this report). These volcanic and intrusive rocks are characterized by high-silica compositions and are separable into two principal subgroups (peraluminous and peralkaline) on the basis of major- and minor-element chemistry, mineralogy, isotopic traits, and associations with particular types of mineralization or geochemical enrichment (Stuckless and others, 1982a, b, prese; Elliott, 1983; Cole, 1984b, this report).

The granitic rocks of the Qitan complex are typical of the peraluminous subgroup of these rocks, whereas the Humaliyah formation and the dikes of the Sanidine porphyry unit are more closely related to the peralkaline subgroup. The close association of these two subgroups in space and time is consistent with the conclusion

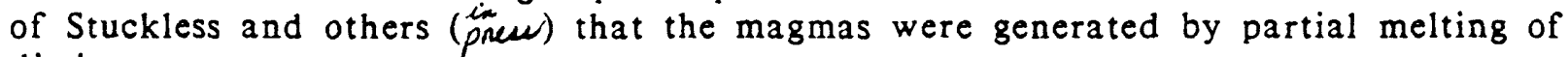
distinct source terranes.

Isotopic characteristics in particular indicate that the peraluminous magmas were either melted from or incorporated older crustal materials during their formation (Stuckless and others, $\dot{p}$ new). The Qitan complex is the source of much of these data and the presence of possible relict cordierite in its granites is consistent with derivation from crustal materials. These granites were probably water-rich, based on liquidus biotite, probable primary muscovite, common pegmatite and aplite, and the gas-phase breccia beneath the roof, and therefore must have been generated at relatively shallow depth (Wyllie and others, 1976). 
Stuckless and others (1984) conclude that the peralkaline granite magmas did not substantially interact with older, crustal materials during formation. The presence of sodium-potassium feldspar phenocrysts (rather than two separate feldspars) in the Humaliyah formation rhyolite and the Sanidine porphyry unit indicates water-poor magma (Tuttle and Bowen, 1958). A similar conclusion. is reached for the peralkaline granites in adjoining areas (du Bray, prear; Cole, 1984c,pro\%, and thus it is possible that peralkaline magmas originated at greater depth than peraluminous magmas (Wyllie and others, 1976).

Deposition of the Cambrian and Lower Ordovician Saq Sandstone marks the beginning of general crustal stability over the northeastern Shield (fig. 9), and is inferred to have followed a protracted period of weathering and planation (Powers and others, 1966; Whitney, das3. However, most of the weathering and erosion may have taken place during the interval $615 \mathrm{Ma}$ to $585 \mathrm{Ma}$. This conclusion is based on the fact that the youngest granites of the region (for example, the Qitan complex) are 100 to $300 \mathrm{~m}$ higher than the inferred altitude of the base of the Saq and must have been topographically high at the time. Deposition of the Saq may have begun shortly after intrusion of the youngest granites (ca. $570 \mathrm{Ma}$ ) because this amount of topographic relief would probably not have survived an extended erosion cycle. 


\section{DATA STORAGE}

Unpublished data generated in the course of DMMR sub-project 2.01 .18 and summarized or incorporated in this report are available for examination at the Jiddah office of the USGS. They are catalogued as DMMR Data-File USGS-DF-04-33 and stored in a box-file, which contains:

* Map showing station locations, station/sample numbers, secondary (dirt) roads, and station altitudes (barometric; superceded by data released from the MPMR Aerial Survey Department in 1984); paper copy in file; stable-base mylar stored separately.

* Computer tabulation of digitized station locations (latitude - longitude).

* Computer tabulation of chemical data for all samples analyzed and collected from this quadrangle.

* Photocopies of original field notes, including total-count radioactivity measurements (semiquantitative, not referenced to known standards).

* Contact black-and-white prints, 1:60,000-scale aerial photography, with original field notations.

* Modal composition data for plutonic rocks (original analyses, tabulated percentages, triangular composition diagrams).

* Thin sections and rock slabs stored separately.

\section{Entries into Mineral Occurrence Documentation System}

MODS 3114: renamed Jabal Akkash from Sukhaybarat Northeast

MODS 3940: new entry (May, 1984) for Akkash West occurrence 


\section{REFERENCES CITED}

Aguttes, J., and Chaumont, P., 1974, Geology and mineral exploration of the Jabal Mawan quadrangle $(25 / 41$ D): Bureau de Recherches Geologiques et Minieres (Saudi Arabian Mission) Report 74-JED-11, 63 p., scale 1:100,000.

Andreasen, G. E., and Petty, A. J., 1974, Total intensity aeromagnetic map of the Wadi ar Rimah quadrangle and part of the Northern Tuwayq quadrangle, Kingdom of Saudi Arabia: Saudi Arabian Directorate General of Mineral Resources Geologic Map GM-11, 3 p., scale 1:500,000.

ARGAS (Arabian Geophysical and Surveying Company), 1967, Airborne magnetometer-scintillation counter survey of the Arabian Shield - Area 3: Saudi Arabian Directorate General of Mineral Resources unpublished maps, no text, scale $1: 100,000$.

Arnold, M. K., 1984, Petrographic and photogeologic review of the Wadi al Jarir quadrangle, sheet $25 / 42 \mathrm{C}$, and field investigations in the Aban al Ahmar quadrangle, sheet 25 F: Saudi Arabian Deputy Ministry for Mineral Resources Data File USGS-DF-04-32.

Baubron, J. C., Delfour, J., and Vialette, Y., 1976, Geochronological measurements ( $\mathrm{Rb} / \mathrm{Sr} ; \mathrm{K} / \mathrm{Ar}$ ) on rocks of the Arabian Shield, Kingdom of Saudi Arabia: Bureau de Recherches Geologiques et Minieres (Saudi Arabian Mission) Report 76-JED-22, 152 p.

Begg, E. J. B., 1980, The assessment of certain gold occurrences in the Jurdhawiyah-Af if area: Riofinex Geological Mission Open-File Report RF-OF-01-20, 46 p.

Beurrier, M, and Villey, M, 1982, Reconnaissance geology and mineral exploration of the Dukhnah quadrangle, sheet 25/43 D: Saudi Arabian Deputy Ministry for Mineral Resources Technical Record BRGM-TR-02-6, 25 p., scale 1:100,000.

Bohannon, R. G., 1984, Reconnaissance geology of the Ash Shubaykiyah quadrangle, sheet 25/43 C, Kingdom of Saudi Arabia: Saudi Arabian Deputy Ministry for Mineral Resources Open-File Report USGS-OF-04-50, no text, scale 1:100,000. A1so, 1985, U.S. Geological Survey Open-File Report 85-130.

Boyle, D. McK., and Atkinson, V. G., 1982, Assessment of the placer-gold potential of the Arabian Shield: Results of reconnaissance investigations: Saudi Arabian Deputy Ministry for Mineral Resources Open-File Report RF-OF-02-26, 61 p.

Boyle, D. McK., and Howes, D. R., 1983, Assessment of the gold potential of the Nafud al Urayq area, northwest Najd: Saudi Arabian Deputy Ministry for Mineral Resources Open-File Report RF-OF-03-9, 58 p.

Bramkamp, R. A., Ramirez, L. F., Brown, G. F., and Pocock, A. E., 1963, Geologic map of the Wadi ar Rimah quadrangle, Kingdom of Saudi Arabia: U.S. Geological Survey Miscellaneous Geologic Investigations Map I-206 A, scale 1:500,000.

Brosset, R., and Delfour, J., 1972, Geology and mineral exploration of the Wadi al Jif $n$ quadrangle, photomosaic 49 east: Bureau de Recherches Geologiques et Minieres (Saudi Arabian Mission) Report 72-JED-14, 58 p., scale 1:100,000. 
Brown, G. F., Jackson, R. O., Bogue, R. G., and Elberg, E. L., Jr., 1963a, Geologic map of the Northwestern Hijaz quadrangle, Kingdom of Saudi Arabia:. U. S. Geological Survey Miscellaneous Geologic Investigations Map GM-204 A, scale 1:500,000.

Brown, G. F., Layne, N., Goudarzi, G. H., and MacLean, W. H., 1963b, Geologic map of the Northeastern Hijaz quadrangle, Kingdom of Saudi Arabia: U. S. Geological Survey Miscellaneous Geologic Investigations Map GM-205 A, scale 1:500,000.

Calvez, J. Y., Alsac, C., Delfour, J., Kemp, J., and Pellaton, C., 1983, Geologic evolution of western, central, and eastern parts of the northern Precambrian shield, Kingdom of Saudi Arabia: Saudi Arabian Deputy Ministry for Mineral Resources Open-File Report BRGM-OF-03-17, 57 p.

Calvez, J. Y., and Kemp, J., 1982, Geochronological investigations in the Mahd adh Dhahab quadrangle, central Arabian Shield: Saudi Arabian Deputy Ministry for Mineral Resources Technical Record BRGM-TR-02-5, 41 p.

Cole, J. C., 1981, Reconnaissance geology of the Al Jurdhawiyah quadrangle, sheet 25/42 D, Kingdom of Saudi Arabia: U. S. Geological Survey Saudi Arabian Mission Miscellaneous Map 44, no text, scale 1:100,000.

, 1982, Base data for the Al Jurdhawiyah quadrangle, sheet $25 / 42$ D: Saudi Arabian Deputy Ministry for Mineral Resources Data File USGS-DF-02-8.

, 1984a, Geologic setting and igneous controls of mineralization, in Smith, C. W., and others, $1984 \mathrm{a}_{\text {, }}$ Preliminary report on the gold deposits at Al Habla, Kingdom of Saudi Arabia: Saudi Arabian Deputy Ministry for Mineral Resources Open-File Report USGS-OF-04-54, 43 p. Also, 1985, U.S. Geological Survey OpenFile-Report 85-128.

, 1984b, Base data for the Uqlat as Suqur quadrangle, sheet 25/42 A: Saudi

Arabian Deputy Ministry for Mineral Resources Data File USGS-DF-04-33.

, 1984c [1985], Reconnaissance geology of the Al Abanat quadrangle, sheet 25/42 B, Kingdom of Saudi Arabia: Saudi Arabian Deputy Ministry for Mineral Resources Open-File Report USGS-OF-05-17, scale 1:100,000. Also, 1985, U.S. Geological Survey Open-File Report 85- 721 .

in press, Geology of the Aban al Ahmar quadrangle, sheet $25 \mathrm{~F}$, Kingdom of Saudi Arabia: Saudi Arabian Deputy Ministry for Mineral Resources Geoscience Map GM-105-A, scale 1:250,000.

Colliver, I. C., and Wollett, A. C., 1981, Halaban-Al Batrah-Nuqrah-Afif reconnaissance assessment, in Riofinex Geological Mission, 1981, Reconnaissance assessment of mineral potential of selected areas of the Arabian Shield: summary of results for the programme years 1398-1399 and 1399-1400: Riofinex Geological Mission (Saudi Arabia) Open-File Report RF-OF-01-23, p. 28-30.

Cooper, J. A., Stacey, J. S., Stceser, D. B., and Fleck, R. J., 1979, An evaluation of the zircon method of isotopic dating in the southern Arabian craton: Contributions to Mineralogy and Petrology, vol. 68, p. 429-439.

Darbyshire, D. P. F., Jackson, N. J., Ramsay, C. R., and Roobol, M. J., 1983, Rb-Sr isotope study of latest Proterozoic volcano-sedimentary belts in the central Arabian Shield: Journal Geological Society of London, vol. 140, p. 203-213. 
Delfour, J., 1977, Geology of the Nuqrah quadrangle, sheet 25 E, Kingdom of Saudi Arabia: Saudi Arabian Deputy Ministry for Mineral Resources Geologic Map GM-28-A, 32 p., scale 1:250,000.

1979, Geology of the Halaban quadrangle, sheet $23 \mathrm{G}$, Kingdom of Saudi Arabia: Saudi Arabian Deputy Ministry for Mineral Resources Geologic Map GM-46-A, 32 p., scale 1:250,000.

1981, Geology of the Al Hissu quadrangle, sheet $24 \mathrm{E}$, Kingdom of Saudi Arabia: Saudi Arabian Deputy Ministry for Mineral Resources Geologic Map GM-58-A, 47 p., scale 1:250,000.

DMMR (Deputy Ministry for Mineral Resources), 1984, Saudi Arabian code of lithostratigraphic classification and nomenclature: Second edition: Saudi Arabian Deputy Ministry for Mineral Resources Technical Manual DM-TM-04-1, 16 p.

Dirom, G. A., 1946, Preliminary report on ancient gold mines, Najd, Saudi Arabia: Saudi Arabian Directorate General of Mineral Resources Open-File Report 23, 36 p.

du Bray, E. A., in puent Reconnaissance geology of the Jabal as Silsilah quadrangle, sheet 26/42 D, Kingdom of Saudi Arabia: Saudi Arabian Deputy Ministry for Mineral Resources map series,... 52 p., scale 1:100,000.

Elliott, J. E., 1983, Peralkaline and peraluminous granites and related mineral deposits of the Arabian Shield, Kingdom of Saudi Arabia: Saudi Arabian Deputy Ministry for Mineral Resources Open-File Report USGS-OF-03-56, 37 p.

Fakhry, A. O., 1941, No. 2 report, trip (in the northeast Hijaz) from 1 Mar. to 30 May 1941: Najd, Saudi Arabia: Saudi Arabian Directorate General of Mineral Resources Open-File Report 20, 22 p.

Fisher, R. V., 1961, Proposed classification of volcaniclastic sediments and rocks: Bulletin Geological Society of America, vol. 72, p. 1409-1414

1966, Rocks composed of volcanic fragments and their classification: Earth-Science Reviews, vol. 1, p. 287-298.

Fleck, R. J., Greenwood, W. R., Hadley, D. G., Anderson, R. E., and Schmidt, D. L., 1980, Rubidium-strontium geochronology and plate-tectonic evolution of the southern part of the Arabian Shield: U. S. Geological Survey Professional Paper 1131, 38 p.

Fleck, R. J., and Hadley, D. G., 1982, Ages and strontium initial ratios of plutonic rocks in a transect of the Arabian Shield: Saudi Arabian Deputy Ministry for Mineral Resources Open-File Report USGS-OF-03-38, 43 p.

Folk, R. L., 1968, Petrology of sedimentary rocks: Austin, Texas, Hemphill's, 170 p.

Gill, J. B., 1981, Orogenic andesites and plate tectonics: Heidelberg, Springer-Verlag, 390 p. 
Greene, R. C., 1983, Stratigraphy of the Murdama formation between Afif, Halaban, and As Sawadah, Kingdom of Saudi Arabia: Saudi Arabian Deputy Ministry for Mineral Resources Open-File Report DM-OF-03-2, 35 p. Also, 1984, U.S. Geological Survey Open-File Report 84-327.

Greenwood, W. R., Stoeser, D. B., Fleck, R. J., and Stacey, J. S., 1982, Late Proterozoic island-arc complexes and tectonic belts in the southern part of the Arabian Shield, Kingdom of Saudi Arabia: Saudi Arabian Deputy Ministry for Mineral Resources Open-File Report USGS-OF-02-8, 46 p. Also, 1983, U.S. Geological Survey Open-File Report 83-296.

Hadley, D. G., and Schmidt, D. L., 1979, Proterozoic sedimentary rocks and basins of the Arabian Shield and their evolution: U. S. Geological Survey Open-File Report 79-1189.

Hotzl, H., Felber, H., and Z8tl, J. G., 1978, The Quaternary development of the upper part of Wadi ar Rimah, in Al-Sayari, S. S., and Z8tl, J. G., eds., Quaternary Period in Saudi Arabia: New York, Springer-Verlag, p. 173-182.

Irvine, T. N., and Baragar, W. R. A., 1971, A guide to the chemical classification of the common volcanic rocks: Canadian Journal of Earth Sciences, vol. 8, p. 523-548.

Jackson, N. J., and Ramsay, C. R., 1980, Time-space relationships of upper Precambrian volcanic and sedimentary units in the central Arabian Shield: Journal of the Geological Society of London, vol. 137, p. 617-628.

Johnson, P. R., 1983a, A preliminary lithofacies map of the Saudi Arabian Shield - an interpretation of the lithofacies and lithostratigraphy of the Proterozoic layered rocks of Saudi Arabia: Saudi Arabian Deputy Ministry for Mineral Resources Technical Record RF-TR-03-2, 72 p., scale 1:1-million.

, 1983b, Reconnaissance mineral exploration of quadrangle $24 \mathrm{~F}$ : Saudi Arabian Deputy Ministry for Mineral Resources Open-File Report RF-OF-03-16, 108 p., scale $1: 250,000$.

Johnson, P. R., and Williams, P. L., 1984, Geology of the Proterozoic rocks of the Jabal Habashi quadrangle, sheet 26 F, Kingdom of Saudi Arabia: Saudi Arabian Deputy Ministry for Mineral Resources Open-File Report USGS-OF-04-10, 87 p., scale 1:250,000. A1so, 1985, U.S. Geological Surver Onen-tile Renort 85-3.

Kleinkopf, M. D., and Cole, J. C., 1982, Geologic interpretation of geophysical data for the Wadi al Jarir and Al Jurdhawiyah quadrangles, sheets 25/42 C and D, Kingdom of Saudi Arabia: Saudi Arabian Deputy Ministry for Mineral Resources Open-File Report USGS-OF-03-1, 29 p. Also, 1983, U.S. Geological Survey Open-File Report 83-371.

Macdonald, E. H., 1982, An assessment of the Riofinex placer gold program: Saudi Arabian Deputy Ministry for Mineral Resources Open-File Report RF-OF-02-9, 62 p.

Morse, S. A., 1980, Basalts and phase diagrams; an introduction to the quantitative use of phase diagrams in igneous petrology: New York, Springer-Verlag, 493 p. 
Muller, Y., 1975, Geology and mineral exploration of the Al Jurdhawiyah area covering quadrangle 25/42 D: Bureau de Recherches Geologiques et Minieres (Saudi Arabian Mission) Report 75-JED-21, 48 p., scale 1:100,000.

Mytton, J. W., 1970, Reconnaissance for mineral deposits in the Precambrian rocks of the Wadi ar Rimah quadrangle, Kingdom of Saudi Arabia: U. S. Geological Survey Open-File Report (IR)SA-121, 75 p.

Pellaton, C., 1984a, Reconnaissance geology of the Jabal ash Shamta quadrangle, 24/42 A, Kingdom of Saudi Arabia: Saudi Arabian Deputy Ministry for Mineral Resources Technical Record BRGM-TR-04-1, 35 p., scale 1:100,000.

1984b, Geology of the Miskah quadrangle, sheet 24 F, Kingdom of Saudi Arabia: Saudi Arabian Deputy Ministry for Mineral Resources Geoscience Map GM-99, scale 1:250,000 [in press].

Powers, R. W., Ramirez, L. F., Redmond, C. D., and Elberg, E. L., Jr., 1966, Geology of the Arabian Peninsula - Sedimentary geology of Saudi Arabia: U.S. Geological Survey Professional Paper 560-D, 147 p.

Quick, J. E. and Doebrich, J. L., ixpres, Geology of the Wadi ash Shubah quadrangle, sheet 26 E, Kingdom of Saudi Arabia: Saudi Arabian Deputy Ministry for Mineral Resources Geoscience Map GM-108-A, scale 1:250,000.

Roobol, M. J., Ramsay, C. R., Jackson, N. J., and Darbyshire, D. P. F., 1983, Late Proterozoic lavas of the central Arabian Shield - evolution of an ancient volcanic arc system: Journal Geological Society of London, vol. 140, p. 185-202.

Schaffner, D. F., 1955a, More important proposed diamond drill holes and brief description of workings in the Mawiyah area: Saudi Arabian Directorate General of Mineral Resources Open-File Report 44, 2 p.

, 1955b, Preliminary report on Al Habla (ancient gold workings):- Saudi Arabian Directorate General of Mineral Resources Open-File Report 51, $11 \mathrm{p}$.

, 1956, Report for the year 1375 A.H. (1955-56) on 53 ancient workings: Saudi Arabian Directorate General of Mineral Resources Open-File Report 65, 63 p.

Schiffman, P., Elders, W. A., Williams, A. E., McDowell, S. D., and Bird, D. K., 1984, Active metasomatism in the Cerro Prieto geothermal system, Baja California, Mexico; A telescoped low-pressure, low-temperature metamorphic facies series: Geology (Boulder), vol. 12, p. 12-15.

Schmidt, D. L., and Brown, G. F., 1982, Major-element chemical evolution of the late Proterozoic Shield of Saudi Arabia: The 1st Symposium of Pan African Crustal Evolution in the Arabia-Nubian Shield, IGCP Project I64

Schmidt, D. L., Hadley, D. G., and Brown, G. F., 1982, Middle Tertiary continental rif $t$ and evolution of the Red Sea in southwestern Saudi Arabia: Saudi Arabian Deputy Ministry for Mineral Resources Open-File Report USGS-OF-03-6, 56 p. Also, 1983, U.S. Geological Survey Open-File Report 83-641. 
Schmidt, D. L', Hadley, D. G., and Stoeser, D. B., 1979, Late Proterozoic cristal history of the Arabian Shield, southern Najd province, Kingdom of Saudi Arabia, in Evolution and Mineralization of the Arabian-Nubian Shield, vol. 2: Oxford - New York, Pergamon Press (King Abdulaziz University, Institute of Applied Geology Bulletin No. 3, vol. 2), p. 41-58.

Smith, C. W., Samater, R. M., Hussain, M. A., Basheer, M. A., and Trent, V. A., 1984a, Preliminary report on the gold deposits at Al Habla, with a section on Geologic setting and igneous controls of mineralization by J. C. Cole: Saudi Arabian Deputy Ministry for Mineral Resources Open-File Report USGS-OF-04-54, 43 p. Also, 1985, U.S. Geological Survey Open-File Report 85-128.

, 1984b, Preliminary report on gold deposits of the An Najadi-Wuday region, Samirah and Uqlat as Suqur quadrangles, Kingdom of Saudi Arabia: Saudi Arabian Deputy Ministry for Mineral Resources Open-File Report USGS-OF-04-48, 26 p. Also, 1985, U.S. Geological Survey Open-File Report 85-129

Snyder, W. S., Dickinson, W. R., and Silberman, M. L., 1976, Tectonic implications of space-time patterns of Cenozoic magmatism in the western United States: Earth and Planetary Science Letters, vol. 32, p. 91-106.

Stacey, J. S., Doe, B. R., Roberts, R. J., Delevaux, M. H., and Gramlich, J. W., 1980, A lead isotope study of mineralization in the Arabian Shield: Contributions to Mineralogy and Petrology, vol. 74, p. 175-188.

Stacey, J. S., and Stoeser, D. B., 1983, Distribution of oceanic and continental leads in the Arabian-Nubian Shield: Contributions to Minerasogy and Petrology. v. 84, p. $91-105$

Stacey, J. S., Stoeser, D. B., Greenwood, W. R., and Fischer, L. B., 1984, U/Pb zircon geochronology and geologic evolution of the Halaban-Al Amar region of the eastern Arabian Shield, Kingdom of Saudi Arabia: Saudi Arabian Deputy Ministry for Mineral Resources Open-File Report USGS-OF-04-30, 37 p.

Stoeser, D. B., and Camp, V. E., in popente Pan-African microplate accretion of the Arabian. Shield: Saudi Arabian Deputy Ministry for Mineral Resources publication.

Streckeisen, A., 1976, To each plutonic rock its proper name: Earth Science Reviews, vol. 12, p. 1-33.

, 1978, Classification and nomenclature of volcanic rocks, lamprophyres, carbonatites, and melilitic rocks: Neues Jahrbuch fur Mineralogie Abhandlungen, Band 134, p. 1-14.

Stuckless, J. S., Hedge, C. E., Wenner, D. B., and Nkomo, I. T., mipolop, Isotopic studies of postorogenic granites from the northeastern Arabian Shield, Kingdom of Saudi Arabia: Contributions to Mineralogy and Petrology

Stuckless, J. S., Knight, R. J., VanTrump, G., Jr., and Budahn, J. R., 1982a, Trace-element geochemistry of postorogenic granites from the northeastern Arabian Shield, Kingdom of Saudi Arabia: Saudi Arabian Deputy Ministry for Mineral Resources Open-File Report USGS-OF-02-91, 34 p. Also, 1983, U.S. Geological Survey Open-File Report 83-287. 
Stuckless, J. S., VanTrump, G. Jr., Bunker,-C. M., and Bush, C. A., in pree, Preliminary report on the geochemistry and uranium favorability of the postorogenic granites of the northeastern Arabian Shield, Kingdom of Saudi Arabia: Proceedings. Pan-African Crustal Evolution in Arabia and northwest Africa, IGCP Project 164.

Tuttle, O. F., and Bowen, N. L., 1958, Origin of granite in the light of experimerital studies in the system NaAlSi${ }_{3} \mathrm{O}_{8}-\mathrm{KAlSi}_{3} \mathrm{O}_{8}-\mathrm{SiO}_{2}-\mathrm{H}_{2} \mathrm{O}$ : Geological Society of America Memoir 74, $153 \mathrm{p}$.

Whitney, J. W., 1983, Erosion history and surficial geology of western Saudi Arabia: Saudi Arabian Deputy Ministry for Mineral Resources Technical Record USGS-TR-04-1, 90 p.

Williams, P. L., 1983, Reconnaissance geology of the Samirah quadrangle, sheet 26/42 C, Kingdom of Saudi Arabia: Saudi Arabian Deputy Ministry for Mineral Resources Open-File Report USGS-OF-04-3, 33 p., scale 1:100,000. so, 1984, U.S. Geological Survey Open-File Report 84-383.

Williams, P. L., and Simonds, F. W., 1985, Reconnaissance geology of the Al Ba'ayith quadrangle, sheet $26 / 41$ D, Kingdom of Saudi Arabia: Saudi Arabian Deputy Ministry for Mineral Resources Open-File Report USGS-OF-05-18, 38p, scale 1:100,000. Also, 19.85, U.S. Geological Survey Open-File Report 85-6/7.

Wyllie, P. J., Huang, W.-L., Stern, C. R., and Maaloe, S., 1976, Granitic magmas: possible and impossible sources, water contents, and crystallization sequences: "Canadian Journal of Earth Sciences, vol. 13, p. 1007-1019.

Young, E. J., 1982, Reconnaissance geology of the Wadi al Jarir quadrangle, sheet 25/42 C, Kingdom of Saudi Arabia: Saudi Arabian Deputy Ministry for Mineral Resources Open-File Report USGS-OF-02-54, no text, scale 1:100,000. A1so, 1982, U.S. Geological. Survey, Open-File Report 82-601. 